Universidade de São Paulo

Faculdade de Medicina de Ribeirão Preto

\title{
2019
}

\section{Perspectiva de mulheres sobre uma atividade educativa voltada ao assoalho pélvico: estudo qualitativo}
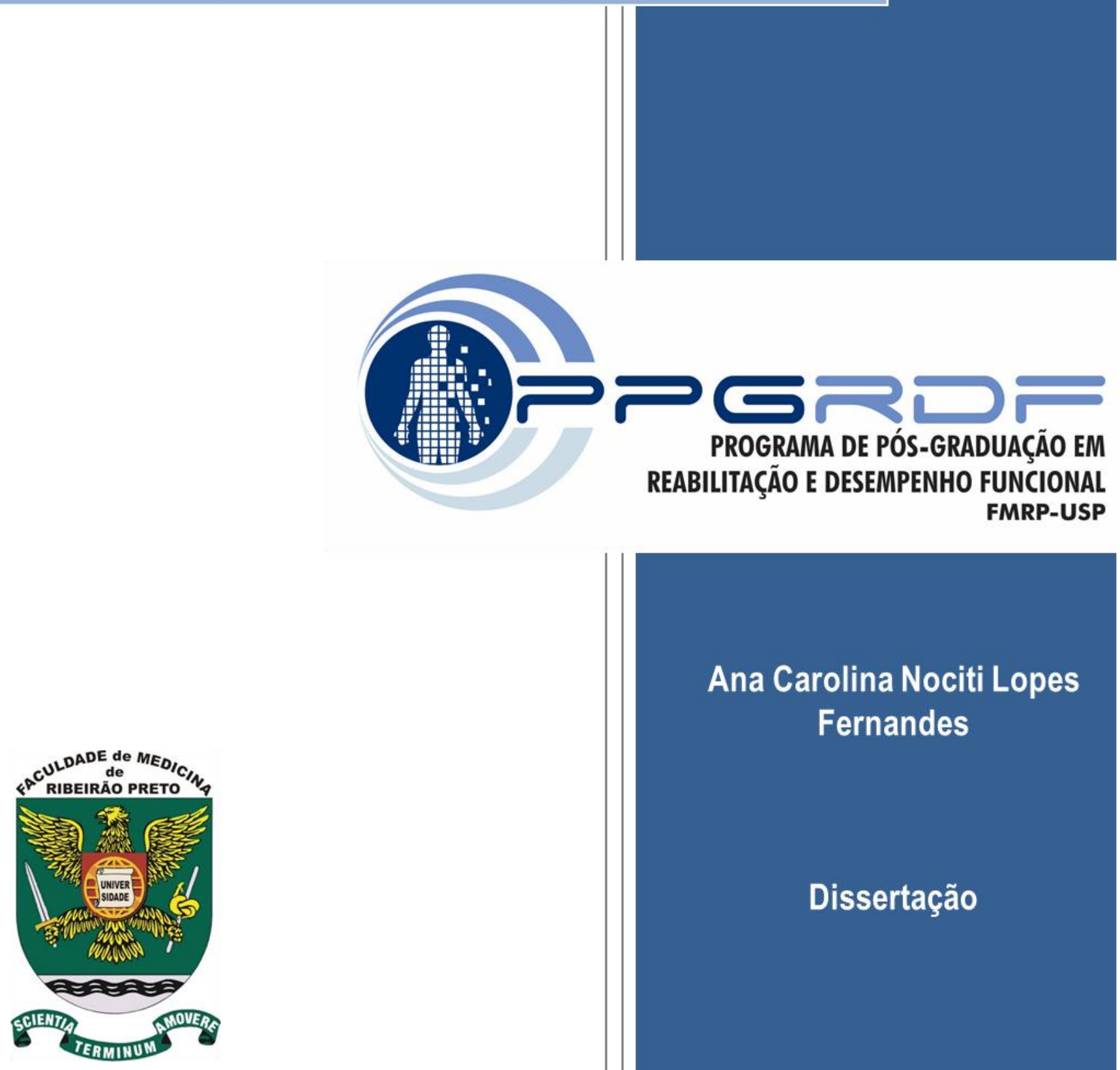

Ana Carolina Nociti Lopes

Fernandes

Dissertação 


\section{ANA CAROLINA NOCITI LOPES FERNANDES}

Perspectiva de mulheres sobre uma atividade educativa voltada ao assoalho pélvico: estudo qualitativo

Versão Corrigida. A versão original encontra-se disponível tanto na Biblioteca da Unidade que aloja o Programa, quanto na Biblioteca Digital de Teses e Dissertações da USP

Dissertação apresentada ao Departamento de Ciências da Saúde da Faculdade de Medicina de Ribeirão Preto da Universidade de São Paulo para obtenção do título de mestre em Ciências.

Área de concentração: Reabilitação e Desempenho Funcional

Orientação: Profa. Dra. Cristine Homsi Jorge Ferreira 
Autorizo a reprodução e divulgação total ou parcial deste trabalho, por qualquer meio convencional ou eletrônico, para fins de estudo e pesquisa, desde que citada a fonte

Fernandes, Ana Carolina Nociti Lopes

Perspectiva de mulheres sobre uma atividade educativa voltada ao assoalho pélvico: estudo qualitativo. Ribeirão Preto, 2019.

104 p. : il ; $30 \mathrm{~cm}$

Dissertação de mestrado, apresentada ao Programa de Pósgraduação em Reabilitação e Desempenho Funcional da Faculdade de Medicina de Ribeirão Preto/ USP. Área de concentração: Fisioterapia

Orientadora: Ferreira, Cristine Homsi Jorge

1. Educação em saúde. 2. Saúde da mulher. 3. Fisioterapia. 
FERNANDES, A.C.N.L. Perspectiva de mulheres sobre uma atividade educativa voltada ao assoalho pélvico: estudo qualitativo. 2018. 104 f. Dissertação (Mestrado) Faculdade de Medicina de Ribeirão Preto, Universidade de São Paulo, Ribeirão Preto, 2018.

Dissertação apresentada ao Departamento de Ciências da Saúde da Faculdade de Medicina de Ribeirão Preto da Universidade de São Paulo para obtenção do título de mestre em Ciências.

Aprovado em:

\section{Banca Examinadora}

Prof (a). Dr (a).

Instituição:

Julgamento:

Prof (a). Dr (a).

Instituição:

Julgamento:

Prof (a). Dr (a).

Instituição:

Julgamento: 


\section{DEDICATÓRIA}

Dedico esse trabalho aos meus pais. 


\section{AGRADECIMENTOS}

Gostaria de agradecer aos meus pais, Paula Regina e Antônio Carlos por todo amor e apoio que fez ser possível eu ir atrás do meu sonho e conseguir finalizar essa etapa dele. Obrigada por aguentarem firme sua filha fora de casa, sei que não é fácil. À minha irmã, Ana Júlia, obrigada pela compreensão. Essa conquista não é só minha, é de nós quatro!

Aos meus avós, Maria Rosário e Francisco, gratidão por tudo! Aos meus tios, Ana Claudia e Ali, obrigado por todo carinho e apoio e à Francisco Jr e Kamila por me estimularem a ir além.

Ao meu namorado, Arthur Matos, por manter-se paciente e amoroso mesmo nos momentos que eu estava sobrecarregada, por ouvir meus devaneios e por sempre estar lá por mim. Obrigada por ter conseguido passar por mais essa fase comigo e me desculpa por ter te deixado desesperado em alguns momentos.

Ao trio mais que fantástico, Marina Donzeli, Tatiane Chagas e Karina Ramicelli, por sempre me escutarem quando precisava falar e não terem dó de falarem quando eu precisava ouvir. Obrigada por estarem comigo nessa nova conquista!

Também gostaria de agradecer pela Mia ter entrado no meu caminho. Obrigada por cada ronronado que acalma e mordida de amor que diverte.

À minha professora de graduação, Dra. Maria Cristina C. C. Meirelles, por me fazer ficar encantada com a Fisioterapia em Saúde da Mulher, incentivar meu pensamento crítico e a seguir a carreira acadêmica e me apresentar a Dra. Cristine H. J. Ferreira.

À minha orientadora, Dra. Cristine H. J. Ferreira por ter confiado em mim e me dado a oportunidade de crescimento pessoal e profissional nesses últimos três anos. Pelos conselhos e toda paciência que teve comigo, pelas portas que me abriu para me aprofundar cada vez mais na Fisioterapia em Saúde da Mulher. Sou grata também pelo exemplo que você é de mulher, associativista, defensora da profissão e guerreira. 
Ao Dr. Domingo P. Cena, por toda paciência em explicar e tornar a pesquisa qualitativa mais compreensível. Também gostaria de agradecer pela sua contribuição na condução da pesquisa.

Às fisioterapeutas Michele M. Baranauskas e Elaine C. L. M. Vasconcelos, sou muito grata por todo conhecimento que compartilharam comigo nesses anos, assim como a experiência de prática clínica.

Gratidão Marilia e Samuel por toda a ajuda e paciência nesses três anos!

Às meninas do LAFAP, Thaiana B. Duarte, Maira de M. Franco, Leticia M. de Freitas, Natália Aleixo, Natália Uechi, Caroline C. Pena, Aura Paternina, Viviane Miotto e demais membros do laboratório pelas conversas e confraternizações que ajudam a manter a sanidade mental até dos mais insanos. You rock guys!!

Às alunas da graduação, Mayra e Amanda, que tanto contribuíram no processo de coleta e análise de dados. Muito obrigada, sem vocês esse trabalho não teria sido completo!

Às mulheres que participaram dessa pesquisa, obrigada por terem disponibilizado seu tempo e contribuir grandemente com a pesquisa. Obrigada também pelo crescimento pessoal que vocês me proporcionaram, serei sempre grata por isso!

Por último, mas não menos importante, agradeço à Coordenação de Aperfeiçoamento de Pessoal de Nível Superior (CAPES) pela bolsa de demanda social essencial para minha dedicação a esse e outros projetos.

Obrigado a todos pelas energias positivas!!! 
"E quem não conhece vai ficar apavorado,

"O que tá acontecendo comigo?"

Por isso o tal do conhecimento é importante."

(P5) 


\section{RESUMO}

FERNANDES, A.C.N.L. Perspectiva de mulheres sobre uma atividade educativa voltada ao assoalho pélvico: estudo qualitativo. 2018. $104 \mathrm{f}$. Dissertação (Mestrado) Faculdade de Medicina de Ribeirão Preto, Universidade de São Paulo, Ribeirão Preto, 2018.

A eficácia do treinamento dos músculos do assoalho pélvico (TMAP) está diretamente relacionada à adesão da paciente, enquanto a adesão também está relacionada à obtenção de bons resultados, estabelecendo-se um ciclo que poderia ser influenciado pelo componente educativo direcionado as necessidades da paciente realizado inicialmente nos programas de reabilitação. Trata-se de um estudo qualitativo com objetivo de descrever a perspectiva de mulheres sobre um programa educativo voltado ao assoalho pélvico (AP) feminino e o impacto deste em suas vidas; contextualizar especificidades das atividades educativas vivenciadas pelas participantes; descrever a perspectiva das mulheres sobre a aquisição de novos hábitos de vida a curto (1 semana), médio (3 meses) e longo prazo (5-16 meses) e; descrever as barreiras e facilitadores para participar da atividade educativa e utilizar as orientações recebidas. Foram acompanhados oito grupos educativos durante um período de um ano. Foram realizados três momentos de entrevistas semiestruturadas uma semana, três meses e de cinco a 16 meses após a participação no grupo educativo. As entrevistas foram realizadas com 19, 14 e nove mulheres respectivamente. Foi realizada análise temática dos dados qualitativos. Os temas emergentes da análise foram: (1) Conhecimento desenvolvido com e/ou prévio ao grupo educativo; (2) Sobre o grupo educativo...; (3) Mudança em hábitos de vida após a participação no grupo educativo; (4) Relacionamento com sintomas de disfunções do AP; (5) Representação social e; (6) Busca e adesão ao tratamento para disfunções do AP. O grupo educativo informativo voltado ao AP feminino apresenta estrutura bem definida e adequada sob a perspectiva das mulheres. As mulheres pareceram ter uma boa aceitação da atividade para gerar modificação em hábitos de vida a curto e médio prazo, entretanto a adesão é reduzida a longo prazo. Foram identificados várias barreiras e facilitadores para aderir as orientações do grupo educativo. Os facilitadores mais frequentes foram as informações discutidas no grupo educativo; o desejo das mulheres em melhorar; a o uso de lembretes como a cartilha com o TMAP e; associar o TMAP à atividades de vida diária. Já as principais barreiras foram não lembrar de realizar o TMAP; não entender como realizar o exercício; não reconhecer que tem disfunções do AP; a função da mulher como cuidadora e; carga horária de trabalho.

Palavra-chave: Educação em saúde. Saúde da mulher. Fisioterapia 


\begin{abstract}
FERNANDES, A.C.N.L. Women's perspective about an educational activity related to the pelvic floor: a qualitative study. 2018. $104 \mathrm{f}$. Thesis (Master degree) - Ribeirão Preto Medical School, University of São Paulo, Ribeirão Preto, 2019.

The effectiveness of pelvic floor muscle training (PFMT) is directly related to patient adherence, while adherence is also related to obtaining good results. This cycle could be influenced by the educational component directed to the needs of the patient performed initially in rehabilitation programs. This is a qualitative study that aims to describe the perspective of women about an educational program focused on the female pelvic floor (PF) and its impact on their lives; to contextualize specificities of the educational activity experienced by the participants; to describe the perspective of women to acquire new life habits in a short (1 week), medium (3 months) and long term period of time (5-16 months) after the educational program and; to describe the barriers and facilitators to participate in the educational activity and adhere to the received instructions. Eight educational groups were followed during an one-year period. Three time points of semi-structured interviews were conducted at one week, three months and five to 16 months after the women's participation in the educational group. Th interviews were conducted with 19, 14 and nine women respectively. Thematic analysis of qualitative data was performed. The emerging themes of the analysis were: (1) Knowledge developed with and / or prior to the educational group; (2) About the educational group...; (3) Change in life habits after the educational group; (4) Relationship with PF dysfunctions symptoms; (5) Social representation and; (6) Search and adherence to PF dysfunction treatment. The educational group focused on the female PF has a well-defined and adequate structure from the perspective of women. The women seemed to have a good acceptance of the activity to promote changes in life habits in the short and medium term, however the adherence was reduced in the long term. Several barriers and facilitators to adherence to the instructions performed by the educational activity have been identified. The most frequent facilitators were: the information discussed in the educational group; the desire of women to improve their PF symptom; the use of reminders as the booklet with PFMT and; associate the PFMT to daily life activities. The main barriers were: not to remember to perform PFMT; not to understand how to perform the exercise; not to recognize that they have PF dysfunctions symptoms; the role of the woman as a caregiver and her workload.
\end{abstract}

Keywords: Health education. Women's health. Physiotherapy 


\section{LISTA DE FIGURAS}

Figura 1 - Fluxograma das participantes

Figura 2 - Cartazes para apresentação de jogos associativos para facilitar o processo de ensino-aprendizagem no grupo educativo 


\section{LISTA DE TABELAS}

Tabela 1 - Apresentação dos tópicos de discussão perguntados pelo guia durante a condução das entrevistas que ocorreram uma semana após a finalização do grupo educativo 27

Tabela 2 - Apresentação dos tópicos de discussão perguntados pelo guia durante a condução das entrevistas que ocorreram três meses após a finalização do grupo educativo 28

Tabela 3 - Apresentação das perguntas prioritariamente discutidas durante os grupos focais 28

Tabela 4 - Critérios de avaliação de Guba e Lincoln, técnicas e procedimentos propostos para atingir os critérios 30

Tabela 5 - Relatório de coleta de dados das entrevistas de uma semana após a participação do grupo educativo com apresentação do código das entrevistas semiestruturadas, número de participantes em cada entrevista, identificação do guia e observador, se houve notas de campo elaboradas pela observadora ou documentos pessoais pelas participantes e o tempo de duração de cada entrevista

Tabela 6 - Apresentação dos temas e subtemas identificados durante a análise temática e definições dos temas 33

Tabela 7 - Apresentação dos dados referentes à caracterização da amostra 34

Tabela 8 - Apresentação da frequência de disfunções uroginecológicas na amostra 35

Tabela 9 - Apresentação da frequência de disfunções anorretais na amostra 36

Tabela 10 - Apresentação dos tópicos mais abordados durante o grupo educativo 37

Tabela 11 - Barreiras e facilitadores relacionados a adesão ao grupo educativo 47

Tabela 12 - Apresentação dos facilitadores para a modificação de hábitos de vida identificados por 19 participantes, uma semana após o grupo educativo 61

Tabela 13 - Apresentação dos facilitadores para a modificação de hábitos de vida identificados por 14 participantes, três meses após o grupo educativo. 62

Tabela 14 - Apresentação dos facilitadores para a modificação de hábitos de vida identificados por nove participantes em um intervalo de cinco a dezesseis meses após o grupo educativo

Tabela 15 - Apresentação das barreiras para a modificação de hábitos de vida identificados por 19 participantes, uma semana após o grupo educativo 65 
Tabela 16 - Apresentação das barreiras para a modificação de hábitos de vida identificados por 14 participantes, três meses após o grupo educativo

Tabela 17 - Apresentação das barreiras para a modificação de hábitos de vida identificados por nove participantes, em um período de cinco a 16 meses após o grupo educativo 


\section{LISTA DE ABREVIATURAS E SIGLAS}

ACNLF

ALA

AP

AVDs

C

CSE

COREQ

CHJF

DP

DS

ESSE

FMRP

G1-8

IA

IU

IUE

IUU

IU

MAP

MFS

MG

$\mathrm{N}$

n

POP

$\mathrm{SM}$

$S R Q R$

TBD
Ana Carolina Nociti Lopes Fernandes

Amanda Lima de Alencar

Assoalho pélvico

Atividades de vida diária

Constipação

Centro de Saúde Escola

Consolidated Criteria for Reporting Qualitative Research

Cristine Homsi Jorge Ferreira

Desvio Padrão

Disfunções sexuais

Entrevista semiestruturada

Faculdade de Medicina de Ribeirão Preto

Grupo educativo de 1 a 8

Incontinência anal

Incontinência urinária

Incontinência Urinária de Esforço

Incontinência Urinária de Urgência

Incontinência Urinária Mista

Músculos do Assoalho Pélvico

Mayra F Sidou

Minas Gerais

Número total

Número

Prolapsos dos órgãos pélvicos

Sabrina Martelletto

Standards for Reporting Qualitative Research

Thaiana Bezerra Duarte 
TMAP

USP

$\mathrm{P}$

P1-19

$\mathrm{X}$

Y

Z

Treinamento dos músculos do assoalho pélvico

Universidade de São Paulo

Participante

Participante de 1 a 19

Tempo da entrevista

Número do grupo educativo da participante

Número de entrevistas de participantes do mesmo grupo educativo 


\section{LISTA DE SÍMBOLOS}

$\begin{array}{ll}\% & \text { Porcentagem } \\ < & \text { Menor } \\ > & \text { Maior }\end{array}$




\section{SUMÁRIO}

1. INTRODUÇÃO _ 18

2. JUSTIFICATIVA _ 21

3. OBJETIVOS 22

3.1. OBJETIVO GERAL _ 22

3.2. OBJETIVOS ESPECÍFICOS __ 22

4. METODOLOGIA _ 23

4.1. PARTICIPANTES _ 23

4.2. CARACTERIZAÇÃO DAS PESQUISADORAS __ 23

4.3. ESTRATÉGIAS DE AMOSTRAGEM ___ 25

4.4. ATIVIDADE EDUCATIVA _ 25

4.5. RECRUTAMENTO _ 26

4.6. COLETA DE DADOS _ 27

4.7. ANÁLISE DOS DADOS _ 29

4.8. CRITÉRIOS DE QUALIDADE__ 30

5. RESULTADOS 31

5.1. CARACTERIZAÇÃO DA AMOSTRA___ 34

5.2. CONTEXTUALIZAÇÃO DO GRUPO EDUCATIVO __ 37

5.2.1. Nomenclatura __ 38

5.2.2. Associações _ 38

5.2.3. Facilitadores do processo de ensino-aprendizagem __ 39

5.3. SOBRE O GRUPO... _ 39

5.3.1. Formato do grupo

5.3.2. Adesão ao grupo _ 46

5.4. CONHECIMENTO DESENVOLVIDO COM E/OU PRÉVIO AO GRUPO EDUCATIVO _ 48

5.4.1. Anatomia e função do assoalho pélvico __ 48

5.4.2. Disfunção do assoalho pélvico ___ 49 
5.4.3. Tratamento das disfunções do assoalho pélvico 52

5.4.4. Treinamento dos músculos do assoalho pélvico 55

5.5. MUDANÇA EM HÁBITOS DE VIDA APÓS PARTICIPAÇÃO EM GRUPO EDUCATIVO 56

5.5.1. O que mudou? 56

5.5.2. Como faz o treinamento dos músculos do assoalho pélvico em casa 58

5.5.3. O que facilitou aderir às orientações do grupo educativo? 60

5.5.4. O que dificultou aderir às orientações do grupo educativo? 64

5.5.5. Percepção de mudança nos sintomas de disfunções do assoalho pélvico 68

5.6. RELACIONAMENTO COM SINTOMAS DE DISFUNÇÕES DO ASSOALHO PÉLVICO 69

5.6.1. Os sintomas 70

5.6.2. Influência e impacto das disfunções do assoalho pélvico 71

5.6.3. Auto percepção do assoalho pélvico 72

5.7. REPRESENTAÇÃO SOCIAL 73

5.7.1. Comunicação e estigma 73

5.7.2. Sexualidade 75

5.8. BUSCA E ADESÃO AO TRATAMENTO PARA DISFUNÇÕES DO ASSOALHO PÉLVICO 76

6. DISCUSSÃO 80

6.1. CONTEXTUALIZAÇÃO DA ATIVIDADE DE EDUCAÇÃO EM SAÚDE 80

6.2. PERCEPÇÃO SOBRE A ATIVIDADE EDUCATIVA 82

6.3. MODIFICAÇÃO EM HÁBITOS DE VIDA 84

6.4. FATORES MODIFICADORES DA ADESÃO 85

6.5. IMPLICAÇÕES PRÁTICAS 86

6.6. LIMITAÇÕES DO ESTUDO 87

7. CONCLUSÃO 88

8. REFERÊNCIAS _ 89

9. APÊNDICES _ 94

10. ANEXOS 100 


\section{INTRODUÇÃO}

Os músculos do assoalho pélvico (MAP) são componentes do assoalho pélvico (AP) cuja função está relacionada ao suporte dos órgãos pélvicos, manutenção das continências urinária e anal, e a função sexual (BO; SHERBURN, 2005; YIOU et al., 2009). A associação entre o enfraquecimento dos MAP e os prolapsos dos órgãos pélvicos (POP), incontinência urinária (IU), disfunções anorretais como constipação (C) e incontinência anal (IA), além de disfunções sexuais (DS) foram demonstradas por DeLancey em 1996 e confirmadas em outros estudos, sendo a disfunção mais prevalente a IU (BO et al., 2015; HERBRUCK, 2008; TAMANINI et al., 2017; WOODLEY et al., 2017; WU et al., 2014).

A prevalência de IU em mulheres brasileiras com idade superior a 60 anos é 28,2\% (TAMANINI et al., 2017). Considerando que a população brasileira é de, aproximadamente, 190.756.000 habitantes, sendo 10,8\% pessoas com idade superior a 60 anos, dos quais, pelo menos 51\% são mulheres (IBGE, 2013). Podemos estimar que, atualmente, mais de 581 mil brasileiras convivem com o sintoma.

Existem diversas opções terapêuticas para a IU feminina, incluindo o uso de medicamentos, cirurgia e tratamento fisioterapêutico (AYELEKE et al., 2015). O tratamento reconhecido pela International Continence Society e considerado primeira opção terapêutica para tratamento de IU feminina é o treinamento dos músculos do assoalho pélvico (TMAP) (ABRAMS et al., 2010; DUMOULIN et al., 2015).

Sabe-se atualmente que a melhora ou cura dos sintomas de disfunções do AP está relacionado com a adesão à abordagem proposta e à informação da paciente sobre a função e localização dessa musculatura (BO; SHERBURN, 2005; DUMOULIN et al., 2015; GLISOI; GIRELLI, 2011; HAY-SMITH et al., 2011).

A adesão ao TMAP está intimamente relacionada com a satisfação e o relato da paciente sobre a eficácia do mesmo (HAY-SMITH et al., 2016; KANDADAI et al., 2014). Mulheres com bexiga hiperativa relatam maior satisfação e eficácia do TMAP quando possuem maior nível de conhecimento sobre a etiologia, fisiologia, diagnóstico e tratamento (SMITH et al., 2011). Para tais mulheres, seria necessária uma melhor comunicação entre 
terapeuta e paciente, ampliando o conhecimento das pacientes a fim de que adquiram expectativas reais acerca do tratamento, otimizando seus resultados e a satisfação com o mesmo (SMITH et al., 2011).

Doshani et al. (2007) relataram uma insatisfação de mulheres sobre o modo que foram orientadas sobre o TMAP, não sendo justificada e explicada sua importância ou o benefício a longo prazo. Para elas, pequenos grupos de discussão seriam o ideal para uma melhor compreensão das disfunções do assoalho pélvico e dos tratamentos disponíveis. As pacientes também destacaram uma dificuldade em saberem se estavam fazendo o exercício corretamente (DOSHANI et al., 2007).

Considerando a falta de conhecimento das mulheres sobre os MAP amplamente discutida na literatura atual (DE FREITAS et al., 2018; DE ANDRADE et al., 2018), a necessidade relatada pelas pacientes em conhecerem melhor a anatomia e função dos MAP e a possível influência positiva do componente educativo na eficácia e adesão ao TMAP (ALEWIJNSE et al., 2003a, 2003b; HINES et al., 2007) atividades de educação em saúde estão sendo desenvolvidas (ALEWIJNSE et al., 2003a; BATISTA, 2017; HYAKUTAKE et al., 2016).

$\mathrm{Na}$ literatura, existem poucas recomendações relacionadas à condução de atividades educativas para prevenção e tratamento da IU e poucas diretrizes orientam os profissionais no auxílio das mudanças comportamentais necessárias, considerando-se as especificidades da população alvo (ALVES, 2005; BUSS, 1999; IERVOLINO; PELICIONI, 2001; MATTOS, 2004; STADNICKA, 2002).

$\mathrm{Na}$ atualidade, a investigação qualitativa tem sido utilizada em ciências da saúde para a descrição e interpretação de comportamentos e hábitos de saúde e doença de grupos específicos como população vulneráveis, pacientes e associação de familiares. Os estudos qualitativos publicados na área de ciências da saúde têm descrito a experiência de pacientes com seus problemas de saúde e respectivas opções terapêuticas (DOSHANI et al., 2007; KAO et al., 2015; RIMMER, et al., 2015; ROOS et al., 2014), de programas de reeducação de hábitos de vida (ZACCARDI; WILSON; MOKRZYCKI, 2010) e a adesão a programas preventivos de incontinência urinária (HINES; SENG; MESSER, 2007). 
O uso das metodologias de estudo qualitativo pode contribuir para a elaboração de novas diretrizes, análise de programas de educação em saúde identificando as necessidades da população alvo e a necessidade de possíveis modificações nos mais variados aspectos do programa educativo como conteúdo e material didático utilizados na teoria e prática, além de nomenclatura e associações (CARLINI-COTRIM, 1996; CHIARELLI; COCKBURN, 1999; IERVOLINO; PELICIONI, 2001; WESTPHAL; BÓGUS; FARIA, 1996). Isso poderia, não só melhorar aspectos do atendimento à população, mas também a qualidade de futuras pesquisas que passariam a ser voltadas à necessidade da população (ENTWISTLE et al., 1998). 


\section{JUSTIFICATIVA}

Partindo do pressuposto que a eficácia do TMAP está diretamente relacionada com a adesão da paciente ao tratamento fisioterapêutico proposto e o conhecimento da mesma sobre a condução do tratamento e prognóstico, pode-se observar o estabelecimento do seguinte ciclo: a eficácia do treinamento está diretamente relacionada à adesão da paciente, enquanto a adesão também está relacionada à obtenção de bons resultados, estabelecendo-se um ciclo que poderia ser influenciado pelo componente educativo direcionado as necessidades da paciente realizado inicialmente nos programas de reabilitação.

Apesar de haverem recomendações relacionadas à condução de atividades educativas para prevenção e tratamento de disfunções dos MAP, em especial a IU, não existe um consenso sobre a melhor estrutura e abordagem de um programa educativo. Sendo assim, parece ser essencial a elaboração e condução de estudos que possam gerar uma compreensão mais aprofundada sobre as adequações desse tipo de atividade considerando a perspectiva de mulheres que participaram dessas atividades. 


\section{OBJETIVOS}

\subsection{OBJETIVO GERAL}

Descrever a perspectiva de mulheres sobre um programa educativo voltado ao AP feminino e o impacto deste em suas vidas.

\subsection{OBJETIVOS ESPECÍFICOS}

1) Contextualizar especificidades das atividades educativas vivenciadas pelas participantes;

2) Descrever a perspectiva das mulheres sobre a aquisição de novos hábitos de vida a curto (1 semana), médio (3 meses) e longo prazo (5-16 meses);

3) Descrever as barreiras e facilitadores para participar da atividade educativa e aplicar as orientações realizadas durante a mesma. 


\section{METODOLOGIA}

Trata-se de um estudo qualitativo exploratório aprovado pelo Comitê de Ética em Pesquisa do Centro de Saúde Escola (CSE) da Faculdade de Medicina de Ribeirão Preto Universidade de São Paulo (FMRP-USP) sob número CAAE 59592816.4.0000.5414.

\subsection{PARTICIPANTES}

Foram incluídas no estudo as mulheres que preencheram os seguintes critérios de elegibilidade estabelecidos: participar de no mínimo três dos quatro encontros do grupo educativo voltado ao assoalho pélvico feminino que ocorre no CSE.

Foram excluídas da pesquisa mulheres que participaram de menos de três encontros do grupo educativo, não aceitaram participar da pesquisa ou que não puderam ser contactadas ou não compareceram à primeira entrevista.

\subsection{CARACTERIZAÇÃO DAS PESQUISADORAS}

A equipe envolvida diretamente com a coleta foi constituída por três membros: ACNLF, MFS e ALA.

ACNLF é uma mulher de 24 anos, branca, solteira, fisioterapeuta, estudante de pósgraduação stricto sensu - nível de mestrado, católica, nulípara, sem queixas de disfunções relacionadas aos MAP. Responsável pelo recrutamento das participantes e condução das entrevistas semiestruturadas, teve seu primeiro contato com as possíveis participantes no último dia do grupo educativo.

Em seu primeiro contato com as participantes apresentou-se como pós-graduanda cujo tema de pesquisa é a adequação do grupo educativo. A pesquisadora apresenta amplo interesse na área de educação em saúde, tendo se envolvido com o tema durante os três últimos anos da graduação. Os principais trabalhos de educação em saúde foram: 1) prevenção de gravidez na adolescência e doenças sexualmente transmissíveis, desenvolvido 
com meninas estudando no $7^{\circ}, 8^{\circ}$ ou $9^{\circ}$ ano de escolas municipais de Uberaba, MG; 2) orientações interdisciplinares à puérperas da maternidade do Hospital das Clinicas de Uberaba; 3) Orientações fisioterapêuticas a gestantes de risco habitual em ambiente de sala de espera aguardando consulta obstétrica e 4) Orientações fisioterapêuticas sobre IU à pacientes em sala de espera de ambulatórios do Hospital das Clínicas de Uberaba. A pesquisadora acredita que atividades educativas mais concisas, direcionadas para a necessidade das participantes e que as façam assumir um papel ativo no processo de educação em saúde seja mais adequado para atingir o objetivo de modificação em hábitos de vida.

MFS é uma mulher de 22 anos, branca, solteira, com ensino superior incompleto, estudante, sem religião, nulípara e sem queixas de disfunções relacionadas aos MAP. Responsável por acompanhar o andamento dos grupos educativos e relatar sua caracterização metodológica. Se apresentava às participantes do grupo educativo como aluna do terceiro ano de fisioterapia da FMRP-USP. Apesar de ter tido contato com as possíveis participantes previamente à inclusão no estudo, ela não teve contato com as mesmas após a inclusão. Seu envolvimento com a pesquisa ocorreu devido a um interesse prévio na área de fisioterapia na saúde da mulher e uma necessidade de ter um primeiro contato com a pesquisa científica, já tendo tido contato com outra atividade de educação em saúde, durante a qual realizava orientações gerais sobre hipertensão arterial à pacientes em sala de espera de um posto de saúde.

ALA é uma mulher de 22 anos, branca, solteira, com ensino superior incompleto, estudante, católica, e sem queixas de disfunções relacionadas aos MAP. Desempenhou a função de guia nas entrevistas semiestruturadas, tendo seu primeiro contato com as participantes no dia da primeira entrevista durante o qual se apresentava como estudante do terceiro ano do curso de fisioterapia. Ela se interessou pelo projeto ao saber o seu objetivo, por ficar instigada a descobrir como os grupos educativos de fisioterapia na saúde da mulher podem mudar os hábitos de vida das pacientes/participantes e o quanto ainda é preciso mudar nestes grupos para torná-los mais acessíveis. Ela nunca se envolveu previamente em atividades de educação em saúde. 


\subsection{ESTRATÉGIAS DE AMOSTRAGEM}

Trata-se de uma amostra não probabilística intencional e por saturação. $O$ recrutamento de participantes foi interrompido quando a pesquisadora observou informações redundantes oriundas das entrevistas.

\subsection{ATIVIDADE EDUCATIVA}

As atividades do grupo educativo do assoalho pélvico são ministradas pelos estagiários em saúde da mulher do curso de fisioterapia da FMRP-USP sob supervisão e coordenação da Prof ${ }^{a}$. Dra. Cristine Homsi Jorge Ferreira, tendo um encontro semanal com duração aproximada de uma hora durante quatro semanas. Os encontros acontecem às quartas-feiras seguidas das $8 \mathrm{~h}$ às $9 \mathrm{~h}$ com intervalo de duas semanas entre cada grupo.

Antes do início das atividades, os estudantes são orientados pelas fisioterapeutas contratadas do serviço sobre a metodologia usual do grupo a fim de que se organizem dentro do proposto. É disponibilizado um período de duas semanas para os estagiários recrutarem participantes para o grupo educativo, elaborarem materiais pertinentes e estruturarem uma abordagem. A divulgação do grupo pode ser realizada por meio de cartazes ou convites individuais a serem distribuídos em sala de espera do CSE, igrejas, vizinhança dentre outros, mas não pode ser divulgado no Hospital das Clínicas de Ribeirão Preto.

As atividades do grupo educativo devem ser conduzidas dentro do seguinte formato:

- No primeiro encontro é realizado uma dinâmica de apresentação e preconiza-se discutir sobre anatomia feminina (diferenciando os tipos de musculatura), englobando genitália externa feminina, estruturas e função do assoalho pélvico, órgãos pélvicos, físiologia da micção e orientado o "stop test" para elas perceberem a contração dos MAP. O encontro é finalizado com práticas corporais de alongamento, anatomia palpatória, respiração diafragmática, mobilidade pélvica, fortalecimento muscular global ou outros. 
- No segundo encontro busca-se revisar todo conteúdo do primeiro dia seguido de discussão sobre os diferentes resultados do "stop test" das participantes. O conteúdo proposto para esse encontro é a discussão das disfunções do sistema geniturinário, com destaque aos tipos de incontinência urinária, as disfunções anorretais (incontinência e constipação) e sexuais (dispareunia, vaginismo, anorgasmia e alteração da lubrificação), além dos prolapsos dos órgãos pélvicos. O encontro também deve ser finalizado com práticas corporais.

- Como no encontro anterior, o terceiro dia do grupo educativo também começa com uma revisão de todo conteúdo visto previamente seguido de discussão sobre as opções terapêuticas com enfoque na fisioterapia, em como é realizada a avaliação fisioterapêutica, a cinesioterapia e são ensinadas estratégia para inibição da urgência miccional. Explica-se que o tratamento é realizado de acordo com os achados da avaliação. Para finalizar é realizado uma prática do protocolo de TMAP - dez contrações sustentadas por seis segundos com intervalo de doze segundos seguido de seis contrações rápidas que devem ser realizadas na posição deitada, sentada, de quatro apoios e em pé.

- No quarto e último encontro é realizada uma revisão de todo conteúdo abordado, entregue uma cartilha com as informações previamente discutidas e realizada uma confraternização.

A estrutura do grupo educativo tem como objetivo informar mulheres da comunidade com ou sem sintomas de disfunções do AP sobre a estrutura e função dos MAP.

\subsection{RECRUTAMENTO}

Os responsáveis pela condução do grupo educativo apresentaram a pesquisadora (ACNLF) no último dia de atividade. Nesse primeiro momento foi explicado a proposta e a metodologia do estudo e coletado nome e telefone de contato das participantes. Na semana seguinte a pesquisadora ligou para as participantes do grupo educativo para perguntar se elas tinham interesse de participar da pesquisa, caso obtivesse uma resposta positiva agendava-se um horário para realizar da assinatura do termo de consentimento livre e esclarecido 
(APÊNDICE A), responder o questionário clínico para caracterização das participantes (APêNDICE B) e realizar a entrevista semiestruturada (Tabela 1).

Tabela 1 - Apresentação dos tópicos de discussão perguntados pelo guia durante a condução das entrevistas que ocorreram uma semana após a finalização do grupo educativo

\section{Tópicos de discussão}

- Como você teve conhecimento do grupo educativo?

- O que instigou você a participar dele?

- O que você lembra de ter sido discutido no grupo educativo?

- O que você lembra sobre a anatomia da mulher, principalmente sobre os músculos do assoalho pélvico?

-Você achou essa informação importante?

- O que você achou do jeito que foi explicado?

- O que você lembra sobre a incontinência urinária e seus tipos?

- O que você lembra sobre os prolapsos?

- O que você lembra sobre as disfunções intestinais? A incontinência anal e a constipação.

- O que você lembra sobre as disfunções sexuais?

- Você achou essas informações importantes?

- O que você achou do jeito que foi explicado?

- Você conseguiu entender como é a avaliação e tratamento da fisioterapia? O que você lembra sobre isso?

- Você achou essa informação importante?

- O que você achou do jeito que foi explicado?

- As informações que você recebeu no grupo, te fizeram mudar algo na sua vida?

- O que você achou do grupo?

- Mudaria alguma coisa nele?

- Recomendaria ele para alguém?

\subsection{COLETA DE DADOS}

A fim de descrever a dinâmica do grupo educativo, uma pesquisadora (MFS) acompanhou os encontros de todos os grupos realizados no ano de 2017 e os dois primeiros do ano de 2018, totalizando oito grupos. Durante a atividade, a pesquisadora preenchia a ficha de controle correspondente ao diário de campo (APÊNDICE C).

Para avaliação da perspectiva das mulheres sobre a atividade educativa foram realizadas entrevistas semiestruturadas guiadas pelos mesmos tópicos de discussão. As entrevistas ocorreram de forma individualizada ou em duplas, de acordo com a preferência das participantes. 
Participaram das entrevistas as participantes, uma guia (ACNLF) e uma observadora (ALA). A guia era responsável por coordenar toda a dinâmica do grupo, estimulando discussões entre as duplas, impedindo a dispersão do assunto e garantindo que todos os pontos das fichas de discussão fossem finalizados, marcando novo horário e dia caso necessário enquanto a observadora coordenava a gravação das entrevistas e realizava as notas de campo.

Após finalizada as entrevistas, a guia solicitava que as participantes elaborassem documentos pessoais individuais como cartas, blogs, mensagens eletrônicas, quando houvesse necessidade de complementar o conteúdo discutido nas entrevistas e informava que tal documento poderia ser entregue no momento da entrevista subsequente. Três meses após a participação no grupo educativo era agendada a segunda entrevista para discussão dos pontos da ficha de discussão 2 (Tabela 2).

Tabela 2 - Apresentação dos tópicos de discussão perguntados pelo guia durante a condução das entrevistas que ocorreram três meses após a finalização do grupo educativo

\section{Tópicos de discussão}

- O que você lembra de ter sido discutido no grupo educativo?

- As informações que você recebeu no grupo, fez você mudar alguma coisa na vida?

- O que facilitou e dificultou você seguir as orientações que foram passadas?

- Você repassou as informações que recebeu para alguém?

Durante a análise dos dados notou-se a necessidade de aprofundar a discussão em tópicos específicos. As mulheres que participaram da primeira entrevista foram convidadas para uma terceira entrevista semiestruturada. Tal entrevista teve como tópicos de discussão os apresentados na tabela 3. A ficha foi elaborada visando preencher as lacunas observadas.

Tabela 3 - Apresentação das perguntas prioritariamente discutidas durante os grupos focais

\begin{tabular}{cl} 
Área de pesquisa & \multicolumn{1}{c}{ Pergunta } \\
Grupo educativo & O que você acha que foi mais importante no grupo educativo do assoalho pélvico? \\
& Como era sua vida antes da participação no grupo? E como ficou depois? \\
& Que estratégias ensinadas no grupo você usa? Por quê? \\
& Que barreiras te impedem de usar as estratégias ensinadas no grupo? \\
\hline
\end{tabular}




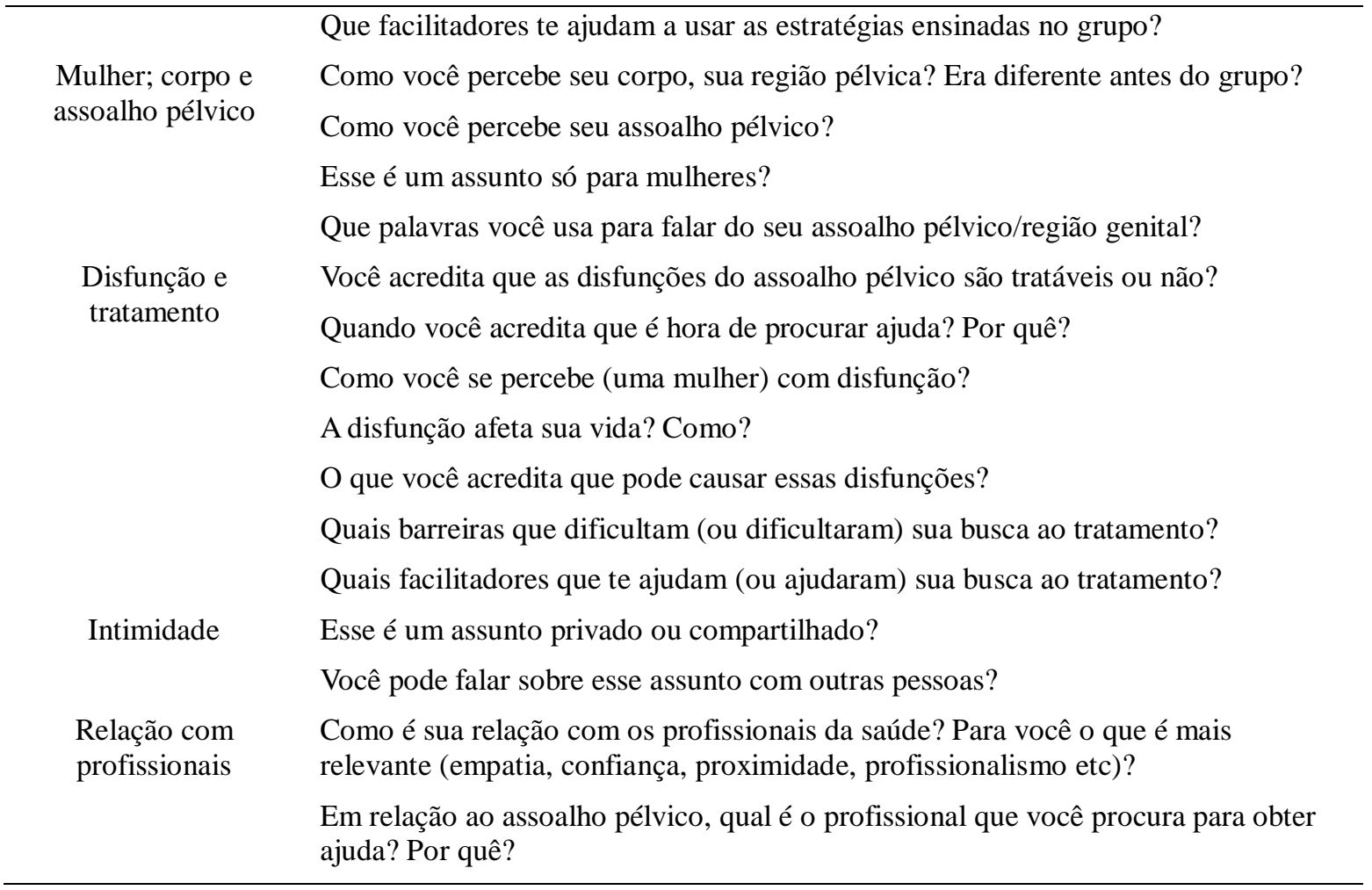

\subsection{ANÁLISE DOS DADOS}

Todas as gravações das entrevistas foram transcritas de forma literal por um membro da equipe de pesquisadoras e conferidas por um segundo membro (ACNLF).

Para os dados de caracterização da amostra foi realizada uma análise descritiva apresentada por média e desvio padrão ou em número e porcentagem. Também foi realizada uma análise descritiva do diário de campo para retratar as atividades relativas ao grupo educativo.

Para a análise das transcrições das entrevistas e documentos pessoais foi aplicada a análise temática, sendo as notas de campo utilizadas durante o processo (BRAUN; CLARKE, 2006; CARPENTER; SUTO, 2008). A análise foi realizada com todos os dados qualitativos obtidos com as entrevistas semiestruturadas. 


\subsection{CRITÉRIOS DE QUALIDADE}

O relato do presente estudo seguiu as recomendações internacionais para pesquisa qualitativa em ciências da saúde: 1) Standards for Reporting Qualitative Research (SRQR) (ANEXO A) (O'BRIEN et al., 2014) e; 2) Consolidated Criteria for Reporting Qualitative Research (COREQ) (ANEXO B) (TONG; SAINSBURY; CRAIG, 2007).

Foram aplicados os critérios adicionais de qualidade de Guba e Lincoln (1985) descritos e correlacionados com a presente pesquisa na tabela abaixo (Tabela 4).

Tabela 4 - Critérios de avaliação de Guba e Lincoln, técnicas e procedimentos propostos para atingir os critérios

\begin{tabular}{|c|c|}
\hline Critério & Técnica apresentada por Guba e Lincoln e procedimento de aplicação \\
\hline \multirow[t]{3}{*}{ Credibilidade } & $\begin{array}{l}\text { Triangulação do investigador: As entrevistas transcritas foram analisadas por um } \\
\text { pesquisador (ACNLF) e conferidas por um segundo pesquisador (MFS) de forma } \\
\text { independente. Divergências entre as análises foram resolvidas em discussão de equipe } \\
\text { (ACNLF, MFS, TBD, LMF, SM e CHJF). }\end{array}$ \\
\hline & $\begin{array}{l}\text { Triangulação das participantes: o estudo incluiu participantes independentemente do } \\
\text { diagnóstico de disfunções relacionadas aos MAP. Desta forma foi obtido diferentes } \\
\text { perspectivas relacionadas a situação em comum, a participação na atividade educativa. }\end{array}$ \\
\hline & $\begin{array}{l}\text { Triangulação dos métodos de coleta de dados: três tempos de entrevistas } \\
\text { semiestruturadas, notas de campo e possíveis documentos pessoais elaborados pelas } \\
\text { participantes. }\end{array}$ \\
\hline Transferibilidade & $\begin{array}{l}\text { Descrições aprofundadas do estudo realizado, fornecendo detalhes das características } \\
\text { dos pesquisadores, participantes, contextos, estratégias de amostragem e os } \\
\text { procedimentos de coleta e análise de dados. }\end{array}$ \\
\hline Confiabilidade & $\begin{array}{l}\text { Auditoria por um pesquisador externo: um pesquisador externo avaliou o protocolo de } \\
\text { pesquisa do estudo, enfocando aspectos relacionados aos métodos aplicados e ao } \\
\text { design do estudo. }\end{array}$ \\
\hline \multirow[t]{2}{*}{ Confirmabilidade } & $\begin{array}{l}\text { Triangulação de investigador, triangulação de participantes e triangulação de coleta de } \\
\text { dados. }\end{array}$ \\
\hline & $\begin{array}{l}\text { A reflexividade do pesquisador foi encorajada através do desempenho de relatórios } \\
\text { reflexivos e descrevendo o raciocínio por trás do estudo. }\end{array}$ \\
\hline
\end{tabular}




\section{RESULTADOS}

O recrutamento aconteceu de Abril de 2017 a Abril de 2018. Durante esse período ocorreram oito grupos educativos sendo que, pelo menos uma participante foi entrevistada por grupo. Participaram da entrevista de uma semana após a finalização do grupo educativo 19 mulheres das quais 14 passaram pela segunda entrevista após 3 meses. Durante a análise dos dados notou-se a necessidade de aprofundar a discussão em determinados conteúdos, sendo proposta a condução de uma nova série de entrevistas. Foram conduzidas três entrevistas semiestruturadas totalizando nove participantes. No fluxograma abaixo é possível observar a dinâmica de recrutamento, avaliação da elegibilidade e coleta de dados.

Figura 1 - Fluxograma das participantes
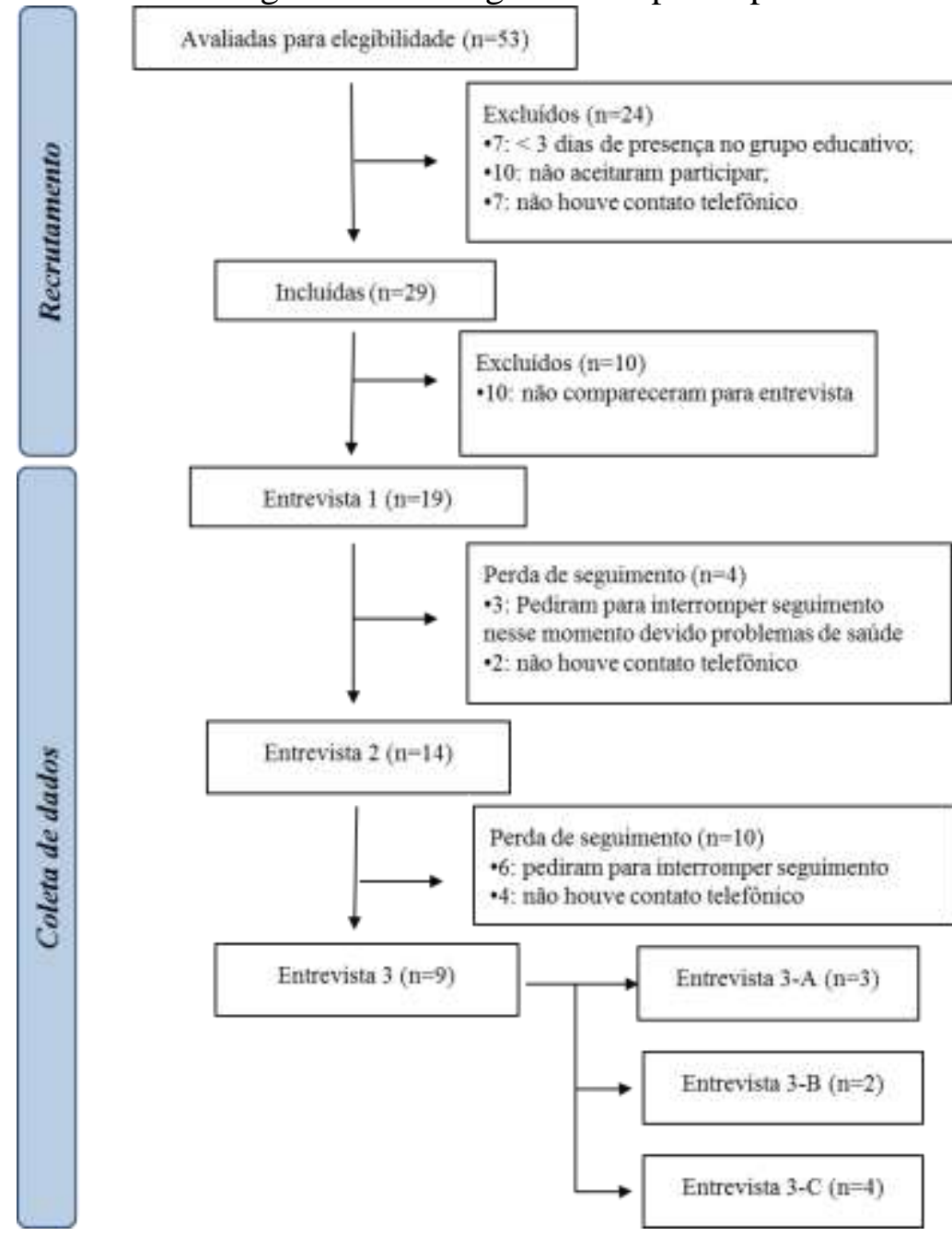
Foram realizadas um total de 32 entrevistas semiestruturadas com 1165 minutos de duração. Deste total de entrevistas, 15 realizadas uma semana após a participação no grupo educativo (11 entrevistas individualizadas e quatro entrevistas em dupla); 14 entrevistas realizadas três meses após a finalização do grupo educativo e; 3 entrevistas semiestruturadas em grupos de duas, três e quatro participantes.

As duplas das primeiras entrevistas foram formadas de acordo com a preferência das participantes sendo os elos parentesco e amizade. Na tabela 5 é possível observar a descrição das características das entrevistas assim como o tempo de duração de cada uma e os documentos coletados. Cabe destacar que nenhuma participante entregou documentos para complementar ou corrigir as informações presentes nas entrevistas.

Tabela 5 - Relatório de coleta de dados das entrevistas de uma semana após a participação do grupo educativo com apresentação do código das entrevistas semiestruturadas, número de participantes em cada entrevista, identificação do guia e observador, se houve notas de campo elaboradas pela observadora ou documentos pessoais pelas participantes e o tempo de duração de cada entrevista.

\begin{tabular}{lcccccc}
\hline $\begin{array}{c}\text { Código da } \\
\text { entrevista }\end{array}$ & $\begin{array}{c}\text { Número de } \\
\text { entrevistadas }\end{array}$ & Guia & Observadora & $\begin{array}{c}\text { Notas de } \\
\text { campo }\end{array}$ & $\begin{array}{c}\text { Documentos } \\
\text { pessoais }\end{array}$ & $\begin{array}{c}\text { Duração da } \\
\text { entrevista }\end{array}$ \\
\hline 1-ESE1-1 & 2 & ACNLF & ALA & Sim & Não & 80 minutos \\
1-ESE2-1 & 1 & ACNLF & MFS & Sim & Não & 26 minutos \\
1-ESE3-1 & 1 & ACNLF & ALA & Sim & Não & 43 minutos \\
1-ESE4-1 & 1 & ACNLF & ALA & Sim & Não & 45 minutos \\
1-ESE4-2 & 1 & ACNLF & ALA & Sim & Não & 42 minutos \\
1-ESE4-3 & 1 & ACNLF & ALA & Sim & Não & 43 minutos \\
1-ESE5-1 & 1 & ACNLF & ALA & Sim & Não & 45 minutos \\
1-ESE5-2 & 2 & ACNLF & ALA & Sim & Não & 36 minutos \\
1-ESE5-3 & 1 & ACNLF & ALA & Sim & Não & 24 minutos \\
1-ESE5-4 & 2 & ACNLF & ALA & Sim & Não & 41 minutos \\
1-ESE6-1 & 2 & ACNLF & ALA & Sim & Não & 44 minutos \\
1-ESE6-2 & 1 & ACNLF & ALA & Sim & Não & 29 minutos \\
1-ESE7-1 & 1 & ACNLF & ALA & Sim & Não & 34 minutos \\
1-ESE8-1 & 1 & ACNLF & ALA & Sim & Não & 52 minutos \\
1-ESE8-2 & 1 & ACNLF & ALA & Sim & Não & 62 minutos \\
2-ESE1-1 & 1 & ACNLF & - & Sim & Não & 21 minutos \\
2-ESE3-1 & 1 & ACNLF & - & Sim & Não & 13 minutos \\
2-ESE4-1 & 1 & ACNLF & - & Sim & Não & 11 minutos \\
2-ESE4-2 & 1 & ACNLF & - & Sim & Não & 20 minutos \\
2-ESE4-3 & 1 & ACNLF & - & Sim & Não & 26 minutos \\
2-ESE5-1 & 1 & ACNLF & - & Sim & Não & 18 minutos \\
2-ESE5-2 & 1 & ACNLF & - & Sim & Não & 8 minutos \\
2-ESE5-3 & 1 & ACNLF & - & Sim & Não & 12 minutos \\
2-ESE5-4 & 1 & ACNLF & - & Sim & Não & 15 minutos \\
2-ESE6-1 & 1 & ACNLF & - & Sim & Não & 14 minutos \\
2-ESE6-2 & 1 & ACNLF & - & Sim & Não & 11 minutos \\
2-ESE7-1 & 1 & ACNLF & - & Sim & Não & 14 minutos \\
\hline
\end{tabular}




\begin{tabular}{clllllc} 
2-ESE8-1 & 1 & ACNLF & - & Sim & Não & 8 minutos \\
2-ESE8-2 & 1 & ACNLF & - & Sim & Não & 16 minutos \\
3-ESE-1 & 3 & ACNLF & ALA & Sim & Não & 110 minutos \\
3-ESE-2 & 2 & ACNLF & ALA & Sim & Não & 75 minutos \\
3-ESE-3 & 4 & ACNLF & ALA & Sim & Não & 127 minutos \\
\hline
\end{tabular}

$\mathrm{ESE}=$ entrevista semiestruturada; o código das entrevistas é formado por: tempo da entrevista (X) + ESE + número do grupo educativo da participante $(\mathrm{Y})$ + número de entrevistas de participantes do mesmo grupo educativo (Z), resultando em X-ESEY-Z, exceto para o terceiro tempo de entrevista que não tem o "Y"; $\mathrm{ACNLF}=$ Ana Carolina Nociti Lopes Fernandes; ALA= Amanda Lima Alencar; MFS= Mayra F. Sidou

$\mathrm{Na}$ análise temática dos dados qualitativos foram identificados 77 códigos, posteriormente agrupados em seis temas: 1) Conhecimento desenvolvido com e/ou prévio ao grupo educativo; 2) Sobre o grupo educativo...; 3) Mudança em hábitos de vida após a participação no grupo educativo; 4) Relacionamento com sintomas de disfunções do assoalho pélvico; 5) Representação social e; 6) Busca e adesão ao tratamento para disfunções do assoalho pélvico. Tanto os códigos quanto subtemas e temas foram derivados da própria análise. A tabela 6 apresenta a definição de cada tema com indicação dos subtemas.

Tabela 6 - Apresentação dos temas e subtemas identificados durante a análise temática e definições dos temas

\begin{tabular}{|c|c|c|}
\hline Temas & Subtemas & Definição dos temas \\
\hline $\begin{array}{l}\text { Tema } 1 \text { - Sobre o } \\
\text { grupo educativo... }\end{array}$ & $\begin{array}{l}\text { - Formato do grupo } \\
\text { - Adesão ao grupo educativo } \\
\text { - Importancia da educação/ prevenção em } \\
\text { saúde } \\
\text { - }\end{array}$ & $\begin{array}{l}\text { Apresentação de informações relativas a percepção } \\
\text { das mulheres sobre a condução do grupo educativo e } \\
\text { fatores relativos à adesão ao mesmo }\end{array}$ \\
\hline $\begin{array}{l}\text { Tema } 2 \text { - } \\
\text { Conhecimento } \\
\text { desenvolvido com } \\
\text { e/ou previo ao grupo } \\
\text { educativo }\end{array}$ & $\begin{array}{l}\text { - Anatomia e função do AP } \\
\text { - Disfunções do AP } \\
\text { - Tratamento das disfunções do AP } \\
\text { - TMAP }\end{array}$ & $\begin{array}{l}\text { Apresentação do conhecimento desenvolvido com } \\
\text { e/ou previo ao grupo educativo }\end{array}$ \\
\hline $\begin{array}{l}\text { Tema } 3 \text { - Mudança em } \\
\text { hábitos de vida após } \\
\text { participação em grupo } \\
\text { educativo }\end{array}$ & $\begin{array}{l}\text { - O que mudou? } \\
\text { - Como faz o TMAP em casa? } \\
\text { - O que facilitou aderir as orientações do } \\
\text { grupo educativo? } \\
\text { - O que dificultou aderir as orientações do } \\
\text { grupo educativo? } \\
\text { - Percepção de mudança nos síntomas de } \\
\text { disfunções do AP }\end{array}$ & $\begin{array}{l}\text { Relato das mudanças realizadas no dia-a-dia das } \\
\text { mulheres que participaram do grupo educativo, } \\
\text { assim como fatores que facilitaram e dificultaram a } \\
\text { adesão às mesmas. Apresentação dos relatos de } \\
\text { mudanças nos sintomas de disfunção do AP com a } \\
\text { adesão às orientações oferecidas durante o grupo, } \\
\text { em especial ao TMAP }\end{array}$ \\
\hline
\end{tabular}




\begin{tabular}{|c|c|c|}
\hline $\begin{array}{l}\text { Tema } 4 \text { - Lidando } \\
\text { com síntomas de } \\
\text { disfunções do AP }\end{array}$ & $\begin{array}{l}\text { - Os sintomas } \\
\text { - Influencia e impacto } \\
\text { - Auto percepção }\end{array}$ & $\begin{array}{l}\text { Tema destinado a descrever a relação das mulheres } \\
\text { com o seu sintoma. Ele engloba a percepção de } \\
\text { existencia do mesmo, a aceitação dos sintomas, o } \\
\text { impacto que ele gera no dia-a-dia e como ela } \\
\text { percebe seu AP, em especial os MAP }\end{array}$ \\
\hline $\begin{array}{l}\text { Tema } 5 \text { - } \\
\text { Representação social }\end{array}$ & $\begin{array}{l}\text { - Comunicação e estigma } \\
\text { - Sexualidade }\end{array}$ & $\begin{array}{l}\text { Apresentação de estigmas presentes na perspetiva } \\
\text { coletiva que reflete na visão individual sobre a } \\
\text { comunicação e expressão de asuntos íntimos }\end{array}$ \\
\hline $\begin{array}{l}\text { Tema } 6 \text { - Busca e } \\
\text { adesão ao tratamento } \\
\text { para disfunções do AP }\end{array}$ & $\begin{array}{l}\text { - Relação profissional da saúde-paciente } \\
\text { - Importancia do atendimento médico } \\
\text { adequado } \\
\text { - Facilitador para tratamento } \\
\text { fisioterapêutico } \\
\text { - Barreira para tratamento fisioterapêutico }\end{array}$ & $\begin{array}{l}\text { O tema apresenta fatores que poderiam influenciar } \\
\text { ou influenciaram na busca e adesão das mulheres ao } \\
\text { tratamento para disfunções do AP }\end{array}$ \\
\hline
\end{tabular}

$\mathrm{AP}=$ assolho pélvico; $\mathrm{TMAP}=$ treinamento dos músculos do assoalho pélvico; $\mathrm{MAP}=$ músculos do assoalho pélvico

\subsection{CARACTERIZAÇÃO DA AMOSTRA}

Os dados relacionados a caracterização da amostra estão apresentados na tabela 7. A amostra é constituída, em sua maioria, por mulheres brancas com idade média de 55 anos variando de 18 a 78 anos, casadas, com ensino médio completo, do lar, praticantes da religião católica com uma média de 2.6 de gestações.

Tabela 7 - Apresentação dos dados referentes à caracterização da amostra

\begin{tabular}{lc}
\hline Variáveis & $\begin{array}{c}\text { Mulheres avaliadas } \\
(\mathbf{N}=\mathbf{1 9})\end{array}$ \\
\hline $\begin{array}{l}\text { Idade Média (DP) } \\
\text { Cor da pele auto relatada }\end{array}$ & $55,3(14.6)$ \\
Branca & \\
Negra & $12(63.16)$ \\
Outras & 0 \\
Estado civil n $(\%)$ & $7(36.84)$ \\
Solteira & \\
Casada & $3(15.79)$ \\
Viúva & $14(73.68)$ \\
Escolaridade n (\%) & $2(10.53)$ \\
Fundamental I & \\
Fundamental II & $4(21)$ \\
Ensino médio & $4(21)$ \\
Ensino Superior & $7(37)$ \\
\end{tabular}




\begin{tabular}{cc}
\hline Ocupação n (\%) & \\
Empregada & $4(21)$ \\
Aposentada & $4(21)$ \\
Do lar & $10(52.6)$ \\
Estudante & $1(5.3)$ \\
Religião n $(\%)$ & \\
Católica & $8(42.1)$ \\
Evangélica & $6(31.6)$ \\
Espirita & $2(10.5)$ \\
Testemunha de Jeová & $2(10.5)$ \\
Cristão & $1(5.3)$ \\
Paridade Média (DP) & \\
Gestações & $2.6(1.73)$ \\
Partos & $2(1.2)$ \\
Cesárias & $1.05(0.97)$ \\
Vaginal & $0.94(1.31)$ \\
Abortos & $0.63(0.95)$ \\
\hline
\end{tabular}

DP= Desvio Padrão; N= Número total; n: número; \%= Porcentagem

Em relação a presença de disfunções uroginecológicas pode-se observar que a amostra apresenta uma elevada prevalência de sintomas de incontinência urinária com um predomínio de incontinência urinária de esforço e sintomas com duração máxima de cinco anos, sendo que metade das mulheres nunca procuraram nenhum tipo de tratamento para seu sintoma. As mulheres que relataram ter realizado tratamento fisioterapêutico para incontinência urinária estavam em atendimento no serviço de fisioterapia no qual o grupo educativo acontece.

Pode-se observar uma menor prevalência de relato de prolapso dos órgãos pélvicos e de disfunções sexuais. Uma leitura aprofundada da prevalência dessas disfunções pode ser realizada na Tabela 8 .

Tabela 8 - Apresentação da frequência de disfunções uroginecológicas na amostra

\begin{tabular}{ccc}
\hline Variáveis & $\begin{array}{c}\text { Mulheres avaliadas } \\
(\mathbf{N}=\mathbf{1 9})\end{array}$ \\
\hline $\begin{array}{c}\text { Relato de IU } \\
\text { Sim }\end{array}$ & $\mathbf{n}(\%)$ & $17(89.5)$ \\
Não & $2(10.5)$ \\
Tipos de IU & $\mathbf{n}(\%)$ & \\
IUE & $8(47)$ \\
IUU & $3(17.6)$ \\
IUM & $2(11.8)$ \\
Enurese noturna & $3(17.6)$ \\
Insensível & $1(5.9)$ \\
\hline
\end{tabular}




\begin{tabular}{|c|c|}
\hline Duração do sintoma n (\%) & \\
\hline$<5$ anos & $13(76.5)$ \\
\hline 5-10 anos & $2(11.8)$ \\
\hline$>10$ anos & $2(11.8)$ \\
\hline Tratamento realizado $\mathrm{n}(\%)$ & \\
\hline Nenhum & $9(52.9)$ \\
\hline Cirúrgico & $1(5.9)$ \\
\hline Medicamentoso & $1(5.9)$ \\
\hline Fisioterapêutico & $4(23.5)$ \\
\hline Cirúrgico + Fisioterapêutico & $1(5.9)$ \\
\hline Medicamentoso + Fisioterapêutico & $1(5.9)$ \\
\hline Relato de POP n (\%) & \\
\hline Sim & $3(15.8)$ \\
\hline Não & $16(84.2)$ \\
\hline Tratamento realizado $\mathrm{n}(\%)$ & \\
\hline Nenhum & $1(33.3)$ \\
\hline Cirúrgico & $1(33.3)$ \\
\hline Fisioterapêutico & $1(33.3)$ \\
\hline Relato de DS n (\%) & \\
\hline Sim & $8(42.1)$ \\
\hline Não & $11(57.9)$ \\
\hline Tipos de DS n (\%) & \\
\hline Dispareunia & $7(87.5)$ \\
\hline Anorgasmia & $1(12.5)$ \\
\hline Duração do sintoma n (\%) & \\
\hline$<5$ anos & $1(12.5)$ \\
\hline $5-10$ anos & $1(12.5)$ \\
\hline$>10$ anos & $6(75)$ \\
\hline Tratamento realizado $\mathbf{n}(\%)$ & \\
\hline Nenhum & $5(62.5)$ \\
\hline Medicamentoso & $2(25)$ \\
\hline Cirúrgico & $1(12.5)$ \\
\hline
\end{tabular}

DS= Disfunções Sexuais; IU= Incontinência Urinária; IUE= Incontinência Urinária de Esforço; IUU= Incontinência Urinária de Urgência; IUM= Incontinência Urinária Mista; $\mathrm{POP}=$ prolapso dos órgãos pélvicos; DS: disfunção sexual; N= Número total; $\mathrm{n}$ : número; \%= Porcentagem ; < = Menor; > = Maior

Assim como o prolapso dos órgãos pélvicos e disfunções sexuais, a prevalência de disfunções anorretais também foi baixa na amostra como apresentado na Tabela 9 .

Tabela 9 - Apresentação da frequência de disfunções anorretais na amostra

\begin{tabular}{lc}
\hline Variáveis & $\begin{array}{c}\text { Mulheres avaliadas } \\
(\mathbf{N}=19)\end{array}$ \\
\hline Relato de IA n (\%) & $3(15.8)$ \\
Sim & $16(84.2)$ \\
Não & \\
Duração do sintoma $\mathbf{n}(\%)$ & $2(66.6)$ \\
$<5$ anos & $1(33.3)$ \\
$\quad>10$ anos & \\
\hline
\end{tabular}




\begin{tabular}{lc}
\hline Tratamento realizado $\mathbf{n}(\%)$ & $2(66.6)$ \\
Nenhum & $1(33.3)$ \\
Medicamentoso & $7(36.8)$ \\
Relato de Constipação $\quad \mathbf{n}(\%)$ & $12(63.2)$ \\
Sim & $7(100)$ \\
Não & \\
Duração do sintoma n (\%) & $1(14.3)$ \\
$\quad>10$ anos & $1(14.3)$ \\
Tratamento realizado n (\%) & $1(14.3)$ \\
$\quad$ Nenhum & $3(42.9)$ \\
Medicamentoso & $1(14.3)$ \\
Tratamentos alternativos & \\
Adequação alimentar & Lavagens intestinais
\end{tabular}

IA: incontinência anal; N= Número total; n: número; \%= Porcentagem; $<=$ Menor; $>=$ Maior

\subsection{CONTEXTUALIZAÇÃO DO GRUPO EDUCATIVO}

Todos os oito grupos observados foram estruturados pelos estagiários seguindo o protocolo especificado nos métodos, entretanto pequenas variações foram observadas nas notas de campo. Na tabela 10 é possível observar essas variações nos conteúdos que foram ministrados nos oito oferecimentos das atividades educativas dos quais cada participante participou de apenas de um.

Tabela 10 - Apresentação dos tópicos abordados durante cada grupo educativo

\begin{tabular}{|c|c|c|c|c|c|c|c|c|}
\hline \multirow{2}{*}{$\begin{array}{c}\text { Tópicos de discussão comuns aos grupos } \\
\text { educativos }\end{array}$} & \multicolumn{8}{|c|}{ Grupo no qual o tópico foi abordado } \\
\hline & G1 & G2 & G3 & G4 & G5 & G6 & G7 & G8 \\
\hline Anatomia externa feminina & $\mathrm{X}$ & & & & $\mathrm{X}$ & & & $\mathrm{X}$ \\
\hline Anatomia interna feminina & $\mathrm{X}$ & $\mathrm{X}$ & $\mathrm{X}$ & $\mathrm{X}$ & $X$ & $\mathrm{X}$ & & $\mathrm{X}$ \\
\hline O que é musculatura lisa e estriada & & $\mathrm{X}$ & $X$ & $\mathrm{X}$ & $\mathrm{X}$ & $\mathrm{X}$ & $X$ & $\mathrm{X}$ \\
\hline Estrutura dos MAP & $\mathrm{X}$ & $\mathrm{X}$ & & $\mathrm{X}$ & $\mathrm{X}$ & $\mathrm{X}$ & $\mathrm{X}$ & $\mathrm{X}$ \\
\hline Função dos MAP & $\mathrm{X}$ & $\mathrm{X}$ & $\mathrm{X}$ & $\mathrm{X}$ & $\mathrm{X}$ & $\mathrm{X}$ & $\mathrm{X}$ & $\mathrm{X}$ \\
\hline Fisiologia da micção & $\mathrm{X}$ & $\mathrm{X}$ & $\mathrm{X}$ & $\mathrm{X}$ & $X$ & $\mathrm{X}$ & $X$ & $\mathrm{X}$ \\
\hline Stop test & $\mathrm{X}$ & $\mathrm{X}$ & $\mathrm{X}$ & $\mathrm{X}$ & $\mathrm{X}$ & $\mathrm{X}$ & $\mathrm{X}$ & $\mathrm{X}$ \\
\hline Hábitos miccionais saudáveis & & $X$ & $X$ & & $\mathrm{X}$ & $\mathrm{X}$ & $X$ & \\
\hline Resposta sexual feminina & & $\mathrm{X}$ & & $\mathrm{X}$ & $\mathrm{X}$ & $\mathrm{X}$ & $\mathrm{X}$ & $\mathrm{X}$ \\
\hline IU e seus tipos & $\mathrm{X}$ & $\mathrm{X}$ & $\mathrm{X}$ & $\mathrm{X}$ & $\mathrm{X}$ & $\mathrm{X}$ & $\mathrm{X}$ & $\mathrm{X}$ \\
\hline Fatores de risco da IU & $\mathrm{X}$ & & $\mathrm{X}$ & $\mathrm{X}$ & $\mathrm{X}$ & $\mathrm{X}$ & $\mathrm{X}$ & $\mathrm{X}$ \\
\hline Estratégias conservadoras de manejo da IU & $\mathrm{X}$ & $\mathrm{X}$ & & & & $\mathrm{X}$ & $\mathrm{X}$ & \\
\hline Incontinência anal e fatores de risco & $\mathrm{X}$ & $\mathrm{X}$ & $\mathrm{X}$ & $\mathrm{X}$ & $\mathrm{X}$ & $\mathrm{X}$ & $\mathrm{X}$ & $\mathrm{X}$ \\
\hline Constipação intestinal e estratégias de manejo & $\mathrm{X}$ & $\mathrm{X}$ & $\mathrm{X}$ & $\mathrm{X}$ & $X$ & $\mathrm{X}$ & $X$ & $\mathrm{X}$ \\
\hline Prolapso dos órgãos pélvicos & $\mathrm{X}$ & $\mathrm{X}$ & $\mathrm{X}$ & $\mathrm{X}$ & $\mathrm{X}$ & $\mathrm{X}$ & $\mathrm{X}$ & $\mathrm{X}$ \\
\hline Disfunções sexuais & $\mathrm{X}$ & $\mathrm{X}$ & $X$ & $\mathrm{X}$ & $X$ & $\mathrm{X}$ & $X$ & $\mathrm{X}$ \\
\hline Avaliação fisioterapêutica completa & $\mathrm{X}$ & $\mathrm{X}$ & $X$ & $\mathrm{X}$ & $\mathrm{X}$ & $\mathrm{X}$ & $\mathrm{X}$ & $\mathrm{X}$ \\
\hline Tratamento fisioterapêutico & $\mathrm{X}$ & $\mathrm{X}$ & $X$ & $\mathrm{X}$ & $X$ & $\mathrm{X}$ & $\mathrm{X}$ & $\mathrm{X}$ \\
\hline
\end{tabular}




\begin{tabular}{lllllllll}
\hline Protocolo de TMAP & $X$ & $X$ & $X$ & $X$ & $X$ & $X$ & $X$ & $X$ \\
\hline
\end{tabular}

$\mathrm{MAP}=$ músculos do assoalho pélvico; TMAP = treinamento dos músculos do assoalho pélvico; $\mathrm{IU}=$ incontinência urinária; G1= grupo educativo 1; G2= grupo educativo 2; G3= grupo educativo 3; G4= grupo educativo 4; G5= grupo educativo 5; G6= grupo educativo 6; G7= grupo educativo 7; G8= grupo educativo 8

Abaixo serão apresentadas especificidades dos grupos relacionadas a nomenclatura, associações e facilitadores do processo de ensino-aprendizagem.

\subsubsection{Nomenclaturas}

De uma maneira geral, os alunos utilizavam termos técnicos seguidos de uma breve explicação do mesmo. A explicação era repetida quantas vezes fosse necessário. De acordo com as notas de campo, os alunos pareciam apresentar mais dificuldade em explicar de forma leiga a fisiologia da micção.

\subsubsection{Associações}

As associações mais comuns feitas pelos estagiários para facilitar a compreensão das participantes foram:

"A Pelve é como uma bacia de roupa sem o fundo e os MAP como o fundo dela"

"Os MAP são como músculos da perna ou braço, que nós conseguimos mexer porque queremos. Enquanto a bexiga é como o músculo do coração, ele não para de bater porque queremos, ele só funciona.

"A bexiga é como um balão de festa cheio e os MAP são como os dedos que seguram a ponta do balão para evitar que o ar saia. "

"Contrair os MAP é fazer uma força para segurar o xixi. "

"A bexiga, medula e cérebro se comunicam. A bexiga manda sinais quando está enchendo e o cérebro responde para esvaziar a bexiga."

Cabe destacar que as associações não foram utilizadas por todos os grupos ao longo do período de um ano. 


\subsubsection{Facilitadores do processo de ensino-aprendizagem}

Para facilitar o processo de ensino-aprendizagem, alguns grupos utilizaram estratégias como quebra-cabeça com os fatores de risco para incontinência urinária, desafios de verdadeiro ou falso com o objetivo de relembrar assuntos que foram discutidos em encontros anteriores, jogos de associação e teatro da avaliação fisioterapêutica. A figura 2 ilustra um desses jogos, no qual uma participante do grupo educativo sorteava uma frase com um sintoma de alguma disfunção do assoalho pélvico e deveria colar no cartaz no espaço referente a disfunção que ela acredita que o sintoma pertencia.

Figura 2 - Cartazes para apresentação de jogos associativos para facilitar o processo de ensino-aprendizagem no grupo educativo

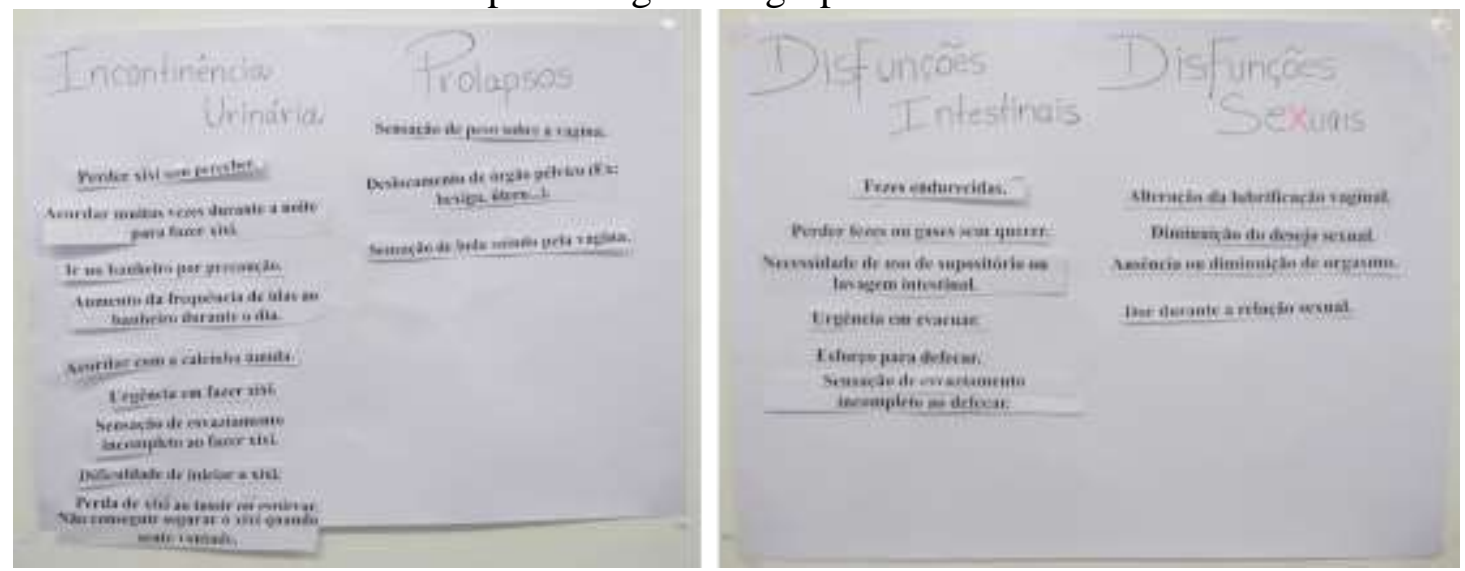

Fonte: acervo pessoal

\subsection{TEMA 1 - SOBRE O GRUPO...}

Este tema apresenta informações relativas a percepção das mulheres sobre a condução do grupo educativo e fatores relacionados à adesão ao mesmo. Ele conta com três subtemas: formato do grupo, adesão ao grupo e importancia da educação/prevenção em saúde. 


\subsubsection{Formato do grupo}

De modo geral as mulheres que participaram do grupo externaram um contentamento com o mesmo, inclusive sobre os estagiários que ministraram o grupo.

"Eu gostei do curso, gostei das meninas, achei super legal.” (P2, 54, IU, C, DS)

"Eu achei ótimo. Bem educativo. Bem instrutivo. Eu achei bom.” (P3, 40, IU, POP)

Em relação a como foi conduzido o grupo, as mulheres relataram satisfação com a didática, analogias, postura e a naturalidade que os alunos abordaram os assuntos discutidos. A presença dos supervisores de estágio durante as atividades do grupo educativo foi relatada como um reforço positivo aos alunos e que trazia mais conforto para as participantes do grupo.

"Não, porque tem várias palavras que a gente não sabe, a gente que estudou não sabe o que é, mas depois eles explicavam e perguntavam quem não entendeu que podia perguntar." (P10, 78, IA)

"Aquilo foi bem legal eu achei interessante essa dinâmica, bem interessante. [dinâmica de identificar a que disfunção corresponde o sintoma] É bom porque sai um pouco daquela coisa de ficar falando fica parecendo que tá dando aula né, então a dinâmica sempre é bom, eu acho." (P17, 67, C, DS)

"Ela ilustrou também, né, então "ah esse aqui é como uma bacia sem a tampa" então ilustrou e a gente assim com ilustração mais simples eu acho que a gente grava mais, então como ela falou "a bacia, imagina a bacia sem a tampa (...)"” (P14, 54, IU, DS)

"Eu achei muito bom! Porque ai uma complementava a outra, eu achei muito bacana. A gente tava com alguma dúvida, já falava, ai elas já tiravam a dúvida ali na hora." (P16, 42, IU, C, DS)

"Ah eles deixaram a gente descontraída, não fazia aquilo como se fosse uma coisa assim né? Que a gente vem e fala da parte sexual assim né. A gente tem um pouco de preconceito, então elas falaram bem natural como se tivesse falando de uma dor de cabeça, uma coisa comum, pelo menos eu me senti assim.” (P14, 54, IU, DS) 
"Eu também percebi isso, é muito bom elas estarem junto, eu acho que faz parte de um bom treinamento né o professor, pessoa responsável acompanhar é muito bom e exatamente por esse fato." (P15, 54, IU, IA)

"Perfeito... foi legal porque os alunos estavam alí explicando, mas qualquer coisa se eles não soubesse, por exemplo, quando aquela moça falou sobre "ah, que mais que a gente tem que evitar de beber para não..." aí a professora respondeu. eles estavam alí mas se precisassem de ajuda..." (P12, 18, IU)

“Às vezes se surgia alguma pergunta que talvez... aí eles pediam ajuda para os professores, mas todos eles ao apresentar, apresentaram bem confiantes, bem preparados e dava para conforme eles passavam para gente era numa linguagem que dava para as pessoas entenderem." (P8, 39)

O grupo educativo foi considerado adequado pelas participantes. Elas relataram uma opinião geral unanime e positiva sobre o grupo. A forma de comunicação dos alunos também agradou as participantes, principalmente o uso de termos técnicos seguidos de explicação de forma leiga associado a demonstrações nos cartazes/ manequins.

"No geral eu sei que isso dai foi muito bom, pelo menos pra mim eu posso dizer pra vocês que foi ótimo.” (P19, 69, IU, IA, C, DS)

"Acho que já falei que o grupo é maravilhoso, dos professores, tudo o que ensinaram. Não tenho nem palavras de tão maravilhoso, para mim foi tudo maravilhoso, eu amei todo mundo, todas as aulas." (P7, 65, IU, C, POP)

"Mas eu vim no horário certinho, que é das oito às nove, participei dos quatro encontros e achei maravilhoso, maravilhoso, nossa! Tudo o que falou, cada aula, cada cena, cada desenho, cada figura, tudo aquilo faz abrir a sua mente e ver que você perdeu tanto tempo da vida sem conhecer seu corpo né. Então eu achei maravilhoso. Gostei muito...” (P7, 65, IU, C, POP)

"Não, deu pra entender. Talvez algumas palavras, como a gente tem pouco estudo ai tinha que repetir para assim, entender, sabe? Igual em receita, tem muitas coisas que a gente não entende." (P4, 63, IU)

"Mas eu acho assim, a visualização é muito importante, visualizar bem o cartaz, mostrar bem o cartaz, os apontamentos direitinho, isso é muito bom." (P19, 69, IU, IA, C, DS)

"Achei muito criativo da parte deles fazer os desenhos, aqueles desenhos explicando para a gente tudo. Explicar, mostrar, falar... nossa!" (P7, 65, IU, C, POP) 
O formato pré-estabelecido, conteúdo e heterogeneidade do grupo foi criticado por quatro participantes; duas acreditam que deveria ter mais tempo de prática, uma que o grupo deveria ser mais homogêneo em relação ao perfil das participantes para facilitar o entrosamento e uma relatou que, ter uma falta não fez diferença para compreensão do conteúdo geral do grupo.

"Não, eu achei muito importante, porque é uma hora só né?! Deu tempo exato, pra mim deu pra entender muito bem." (P5, 46, IU, DS)

"Foi muito fácil... não... eu tenho uma falta também... são 4 encontrou? Eu faltei um que não deu para mim vim, que eu fui colher sangue naquele dia... mas minha vizinha disse que foi igual sabe, as palestras.... eu perguntei se fez alguma diferença e ela, não, foi tudo igual..." (P6, 70, IU, C)

"Então eu achei que teve muita teoria, que a gente... sei lá, é importante a gente saber, mas a gente vem mesmo para o tratamento, a gente quer uma solução para aquilo, entendeu? Então eu acho que deveria mais na prática aqueles exercícios que nunca mais eu fiz e menos teoria." (P14, 54, IU, DS)

"Gostei bastante da teoria, gostei muito, achei muito interessante, é importante teoria, a gente conhecer tudo para depois saber o que você realmente está fazendo, eu gostei muito da teoria mas reafirmo que teria que ter um pouquinho mais de prática mesmo..." (P15, 54, IU, IA)

"Depende muito do nível intelectual eu acho, do nível social, depende muita coisa pra poder participar [de discussões do grupo].” (P17, 67, C, DS)

Apesar das participantes julgarem adequado o conteúdo discutido no grupo educativo, pode-se notar uma dificuldade em lembrar os mesmos, assim como equívocos como pode ser observado os fragmentos de entrevista abaixo. Esse assunto será retomado no tema conhecimento desenvolvido e/ou prévio ao grupo educativo.

"As vezes mesmo que a gente esquece, não sabe explicar depois, conforme você fala a gente lembra, é uma coisa que vai ficar marcada, de repente quando a gente precisar a gente acaba lembrando de alguma forma, então eu acredito que sim, é importante sim." (P8, 39)

"Lembra eu lembro de tudo que vocês ensinaram lá mas eu não consigo responder para você..." (P11,67, IU) 
"Quando você vê que não dá mais. Aí precisa procurar ajuda.” (P18, 48,IU, C, DS)

"[sobre não ter incontinência urinária] mas eu não tô com a calcinha molhada, ai corre pro banheiro." (P17, 67, C, DS)

"Eu tava fazendo fisioterapia lombar, eu nao sei se era do xixi ou se era coluna, eu não entendi porque do jeito que ela tava falando [no grupo], ensinando a fazer os exercícios é a mesma coisa (...)" (P18, 48 IU, C, DS)

"Porque, é... se fala em incontinência eu já penso: incontinência urinária, né?" (P17, $67, \mathrm{C}, \mathrm{DS})$

Os cartazes foram os materiais didáticos utilizado nas atividades do grupo educativo mais elogiados pelas participantes, mas o uso de modelos anatômicos não passou despercebido. Apenas uma participante achou que poderiam ser utilizados outras opções de recursos didáticos.

“Adorei, tão de parabéns. Quem fez aquilo tudo... os desenhos, tudo perfeito. tudo que vocês usaram....” (P5, 46, IU, DS)

"É eu gostei de ver as figuras, porque com as figuras alí vocês explicou muito bem explicadinho. Agora eu acho que sem as figuras, eu tenho a impressão que seria mais difícil de entender... mas com as figuras deu para entender tudo muito bem." (P11,67, IU)

"Lindo, são detalhistas nos desenhos. (...) O que eu mais gostei foi o músculo de contrair, isso ai. foi um cartaz, um desenho que eles fizeram explicando a... esqueci" (P12, 18, IU)

"Eu gostei daquela que a gente vê sabe? A pélvica, o osso, que passa de uma em uma... achei tão bacana..." (P6, 70, IU, C)

"Não foi um material tão rico assim, eu acho que tem mais opções, mas eu acho que foi tranquilo." (P8, 39)

Algumas participantes ofereceram diversas sugestões relacionadas à adesão, comunicação, conteúdo, materiais utilizados e formato do grupo. Para melhorar a adesão ao grupo como oferecer turmas noturnas e/ou online para as pessoas que trabalham poderem participar $(n=1)$. Em relação a comunicação, conteúdo e materiais utilizados: usar termos 
mais simples $(n=2)$, uso de Datashow $(n=1)$, uso de vídeos e fotos $(n=2)$, cartaz com letras maiores $(n=1)$, estimular mais debate $(n=1)$ e incentivar mais realizar os exercícios em casa $(\mathrm{n}=1)$. Em relação ao formato do grupo: oferecer o grupo educativo em um dia $(n=1)$, oferecer mais encontros do grupo $(n=2)$, oferecer uma reciclagem para as mulheres que já participaram do grupo $(n=1)$, ter mais práticas de exercício $(n=2)$, oferecer para a participante a possibilidade de passar por uma avaliação fisioterapêutica para as disfunções do assoalho pélvico $(\mathrm{n}=1)$, trabalhar com uma padronização do perfil das participantes $(n=1)$, oferecer o grupo em um local mais silencioso $(n=1)$, oferecer o grupo em locais que não estejam relacionados à busca por tratamento, como maternidades, para que o objetivo de prevenção seja atingido $(n=1)$ e incentivar o comparecimento de pessoas mais novas $(n=1)$.

Algumas participantes aprontaram que as informações discutidas no grupo é importante por abordar assuntos que eram desconhecidos para ela como as disfunções do assoalho pélvico $(n=7)$, a existência dos músculos do assoalho pélvico $(n=4)$, a organização dos órgãos internos $(n=3)$, opções de tratamento e viabilidade $(n=7)$, treinamento dos músculos do assoalho pélvico e sua importância $(n=10)$. Outras mulheres indicaram que conhecer sobre as disfunções do assoalho pélvico pode ajudar as pessoas a identificarem os sintomas logo que está começando para buscar tratamento $(n=4)$ e até ajudar mulheres a prevenir o aparecimento dos mesmos $(n=5)$. As mulheres que foram atendidas no setor para tratamento de disfunções do assoalho pélvico acharam importante terem passado pelo grupo educativo para compreender melhor o que estava acontecendo durante os atendimentos $(\mathrm{n}=4)$. Outros relatos das mulheres mostraram que participar do grupo educativo gera uma busca pelo autocuidado e aumenta a percepção corporal $(n=8)$, estimula o desejo de buscar o tratamento $(n=2)$ e buscar mais informações $(n=1)$.

"Sim, eu não tinha nem ideia. A pessoa te falava "ai, eu tenho bexiga caída" mas você não sabe o porquê a bexiga cai. Nem imaginava que podia sentir. Muito menos isso! Entendeu? Não tinha ideia disso." (P1, 44, IU, DS)

"Eu ainda não tenho, mas é um problema que muitas mulheres têm e as vezes não sabe como lidar com isso, não sabe nem qual é o profissional qualificado para trabalhar isso." (P8, 39) 
"A sim, porque eu aprendi, então me acrescentou mais. Foi um grande aprendizado, coisas que eu nem imaginava. (...) Os exercícios não é tão difícil assim. Nunca imaginei que um exercício podia, poderia ajudar tanto." (P5, 46, IU, DS)

"Eles explicam bem ué... foi legal... esclareceu bastante o porquê você perde urina, pra que precisa ficar fazendo os exercícios... eu ficava "pra que fica fazendo isso?" aí tem que contrair se não o músculo fíca, né... aí desse jeito" (P12, 18, IU)

"Começou com as aulas primeiro, então hora que chegou no prático na consulta, no tratamento, já tinha conhecido o que ia fazer. Aí veio para a consulta médica, mas eu já tava "acordada" já tinha escutado tudo lá." (P7, 65, IU, C, POP)

"Eu não tinha essa noção e agora eu tenho. Então aí a gente começa a dar um pouquinho mais valor à nossa região pélvica, trabalhar toda a musculatura pra dar sensibilidade tanto anal quanto vaginal. E isso." (P16, 42, IU, C, DS)

"Mas isso não quer dizer que daqui alguns anos não possa acontecer comigo também. Se eu já tiver trabalhando e fortalecendo toda essa musculatura, às vezes eu consigo evitar, né?!" (P8, 39)

"Antes eu assim, eu vivia, num tava prestando atenção no meu corpo, depois que eu vim pra cá que eu vi, eu visualizei.” (P19, 69, IU, IA, C, DS)

Uma outra maneira de identificarmos se o formato do grupo educativo está adequado ou não dentro de seu propósito é se as mulheres com relato de disfunções do assoalho pélvico se identificam com o conteúdo ministrado. Durante a análise temática notamos que oito mulheres se identificaram com alguma informação discutida durante o grupo, e que essa identificação facilitou com que elas lembrassem conteúdos específicos como pode ser notado nos fragmentos abaixo.

"Então... igual eu, eles falaram que é por causa da constipação intestinal. Então que na hora que vai no banheiro, que o intestino é preso, aí você força e relaxa o músculo... e eu não sabia... isso aí foi bom eles terem falado... a minha perda de xixi é isso! Que eu pensava que era de pegar peso, assim, que eu já peguei né... mas é da constipação mesmo..." (P6, 70, IU, C)

"Olha, o que eu lembro mais sobre o que eu perguntei que foi que ela falou que as meninas tavam falando que quando a gente, depois que a gente faz coco se sente uma sensação que não fez tudo. (...) Então, eu lembro bem dessa parte que eu perguntei pra elas porque eu sinto isso, eu acabei de fazer, eu acho que fiz tudo e tenho essa impressão que ainda tem. É mas será que tem mesmo? Porque as vezes a gente vê nossa fez bastante, será que ainda tem mais?" (P17, 67, C, DS) 


\subsubsection{Adesão ao grupo}

Esse subtema apresenta a descrição de fatores relacionados e/ou inerentes à uma boa adesão ao grupo educativo, começando com o como as participantes ficaram sabendo da existência do grupo educativo e o motivo que as levou a participarem.

A maioria das mulheres $(n=9)$ relataram que obtiveram conhecimento sobre a existência do mesmo enquanto esperavam por algum atendimento no posto de saúde seguido por mulheres $(n=5)$ foram convidadas a participar pelos estagiários do estágio em fisioterapia em saúde da mulher durante o atendimento. Três mulheres relataram ter obtido essa informação com amigas e duas não relataram como descobriram o grupo. Todas os fragmentos obtidos das entrevistas sobre o que motivaram as mulheres a participarem do grupo educativo variaram em dois tópicos: a existência de sintomas urinários em si ou familiares $(n=7)$ e o desejo de obter mais conhecimento $(n=12)$.

"Eu também estava lá marcando uma consulta e fui convidada e também achei muito interessante. Por eu estar começando a perder xixi então me interessei muito em aprender." (P2, 54, IU, C, DS)

"Eu vim porque foi indicação da ginecologista e até então assim, eu convivia com esse problema assim, na medida do normal, mas ela observou que tinha um prolapso né, dos órgãos e aí ela me indicou." (P3, 40, IU, POP)

"É porque eu sou muito amiga da (...) e ela tava falando para mim que ela participou, não sei. Aí eu falei para ela que eu gostaria também, porque eu estou com um problema de perca de urina né. Aí foi por isso...” (P6, 70, IU, C)

"Tava fazendo caminhada ai a menina pegou e me chamou, convidou para eu participar e eu fiquei interessada porque muitas coisas você fica sabendo né." (P9, 61, IU)

“A (...) [nome da estagiária] falou que ia ter o grupo e ela falou para eu vir para eu ficar mais informada e saber. Tipo assim, eu fazia uns exercícios mas não sabia a função, sabe? Aí eu participei... para ficar mais informada.” (P12, 18, IU) 
Houveram sugestões para ampliar a divulgação do grupo e, consequentemente a adesão ao mesmo. Uma divulgação mais ampla no CSE, na televisão, internet e ir a empresas e na residência de mulheres da região foram mencionadas uma vez cada uma.

Um fator estritamente relacionado a participação e consequente adesão ao grupo educativo são os fatores que facilitam e dificultam essa participação. Na tabela 11 está apresentado as barreiras e facilitadores para adesão ao grupo. Como barreira destacou-se o horário enquanto a organização funcionou como um facilitador bastante relatado.

Tabela 11 - Barreiras e facilitadores relacionados a adesão ao grupo educativo

\begin{tabular}{|c|c|c|c|}
\hline Relação & Fatores & $\begin{array}{l}\text { Número de } \\
\text { menções }\end{array}$ & Exemplo \\
\hline \multirow[t]{6}{*}{ Barreiras } & Idade & 1 & "Mas são tudo idosinha assim sabe..." (P6, 70, IU, C) \\
\hline & Horário & 4 & "Ela trabalha o dia todo né. E agora né?!" (P5, 46, IU, DS) \\
\hline & & & $\begin{array}{r}\text { "Atrapalhou um pouco pra mim, porque era assim num horário que eu } \\
\text { tinha que ficar uma hora à toa, esperando" }(\mathrm{P} 7,65, \mathrm{IU}, \mathrm{C}, \mathrm{POP}) \\
\text { “(...) às vezes o pessoal trabalha de manhã." }(\mathrm{P} 8,39)\end{array}$ \\
\hline & Localização & 2 & “(...) Porque eu moro muito longe, tenho que pegar dois ônibus." (P8, \\
\hline & Falta de interesse & 2 & $\begin{array}{r}\text { "Eu acho assim, que hoje, as pessoas não se gostam muito. Não se } \\
\text { valorizam, só valoriza quando vê o problema grave, que ai não tem } \\
\text { jeito ou precisa de coisa bastante." (P4, 63, IU) }\end{array}$ \\
\hline & Questões financeiras & 1 & $\begin{array}{r}\text { "Não! A única coisa que atrapalha mesmo é o dinheiro [para } \\
\text { transporte]" (P18, 48, IU, C, DS) }\end{array}$ \\
\hline \multirow[t]{5}{*}{ Facilitadores } & Vontade de aprender & 1 & $\begin{array}{l}\text { "É porque a gente queria aprender né, facilitou porque a gente quer } \\
\text { aprender então... dá uma vontade pra gente." (P10, 78, IA) }\end{array}$ \\
\hline & Apoio familiar & 1 & $\begin{array}{r}\text { "A coisa mais fácil foi meu filho. Se não fosse meu filho" (P18, } 48 \mathrm{IU} \text {, } \\
\text { C, DS })\end{array}$ \\
\hline & Orientação médica & 1 & $\begin{array}{r}\text { "Ai ele [médico] me disse: "vai lá no Cuiabá que você consegue". Ai } \\
\text { eu vim." (P19, 69, IU, IA, C, DS) }\end{array}$ \\
\hline & Organização & 3 & $\begin{array}{l}\text { "Eu já me programei para não fazer nada naquela quarta-feira de } \\
\text { manhã... (...) o que facilitou foi isso, essa organização" (P11,67, IU) }\end{array}$ \\
\hline & & & $\begin{array}{l}\text { "Facilitou de horário sempre o mesmo porque aí a gente (...) então } \\
\text { você ter aquela rotina né, aquele dia, aquele horário, não ficar } \\
\text { mudando, facilitou e mesmo assim eu esqueci depois do feriado.' (P14, } \\
54, \text { IU, DS) }\end{array}$ \\
\hline
\end{tabular}

$\mathrm{P}=$ participante; $\mathrm{IU}=$ incontinência urinária; $\mathrm{IA}=$ incontinência anal; $\mathrm{C}=$ constipação; $\mathrm{DS}=$ disfunção sexual; $\mathrm{POP}=$ prolapso dos órgãos pélvicos

Um resultado importante e que merece ser destacado é o importante papel do grupo educativo em formar multiplicadores de informações. Das 19 participantes, 14 repassaram 
algum tipo de informação obtida durante o grupo educativo para amigas, filhas, netas, mãe, tias, líderes religiosos, conhecidos e/ou marido. Nos fragmentos abaixo é possível observar o processo de repassar informações.

"Eu falo quando alguém me reclama eu ensino, eu falo faz isso assim, assim, falo pras minhas filhas, falo pras minhas netas né, então eu passo assim para minha família né, para qualquer um que reclama, que chega falando alguma coisa no sentido" (P7, 65, IU, C, POP)

"Eu já tenho uma noção já. Com minha filha eu não vou deixar acontecer isso. Eu falei, e ela: "mãe, que que é isso?"... "pois é, filha, acontece isso, e isso, e isso", então..." (P1, 44, IU DS)

"Eu falei para as pessoas do meu trabalho" $(\mathrm{P} 8,39)$

"Estava ensinando minha mãe. E ah, também ensinei uma irmã da Igreja que eu vou, pois ela está esperando vaga pra entrar num grupo desse." (P18, 48, IU, C, DS)

"Só contei para minha filha e pro meu marido... tudo que vocês ensinou aqui e eu aprendi, eu contei..." (P11,67, IU)

\subsection{TEMA 2 - CONHECIMENTO DESENVOLVIDO COM E/OU PREVIO AO GRUPO EDUCATIVO}

Nesse tema será apresentado o conhecimento sobre as disfunções do assoalho pélvico desenvolvido pelas participantes com e/ou prévio ao grupo educativo.

\subsubsection{Anatomia e função do assoalho pélvico}

O subtema consta de apresentação do conhecimento desenvolvido com o grupo educativo sobre a anatomia, função do AP e fisiologia da micção. Apenas oito participantes lembraram sobre o conteúdo de anatomia e função do AP. O assunto mais lembrado foi o posicionamento dos orifícios no períneo, a localização dos MAP e a função de sustentação do AP. Apenas uma participante lembrou aspectos relacionados a fisiologia da micção. 
"Não uai, é onde mostrou a bexiga depois mostrou o canal do intestino né, não, primeiro mostrou a vagina e depois mostrou o canal do ânus né e depois do outro lado que que era?" (P10, 78, IA)

"[localização dos músculos do assoalho pélvico] Na região de baixo." (P18, 48 IU, C, DS)

"Porque o músculo que segura né [a bexiga]." (P1, 44, IU, DS)

“O assolho pélvico era a estrutura que segura e que mantem os órgãos” (P8, 39)

"Eu não lembro se é quando ela recebe a urina, que relaxa, ou se ela contrai na hora que você vai soltar a urina. É, ela relaxa pra receber e contra pra poder soltar" (P16, 42 , IU, C, DS)

Aspectos sobre a função sexual normal feminina foram lembrados por três participantes e uma fez uma analogia entre a diferença entre o feminino e masculino.

"Homem é um ferro a energia e a mulher é um ferro a brasa, tem que esperar todo um processo de brasa esquentar para poder passar a roupa. Agora o homem não, você soca o negócio na tomada e já tá a mil!"” (P1, 44, IU, DS)

"Isso ela explicou toda a anatomia, como funciona a questão do desejo, do início de como tem que ser na mulher até chegar o ápice, no orgasmo, explicou tudo certinho isso." (P8, 39)

\subsubsection{Disfunções do assoalho pélvico}

Nesse subtema haverá a apresentação do conhecimento desenvolvido pelas participantes com o grupo educativo sobre os tipos e as causas das disfunções do AP mais prevalentes. Em relação as disfunções de compartimento anterior, nove mulheres relataram lembrar sobre os tipos de IU discutidos no grupo educativo entretanto houveram alguns equívocos e uma participante lembrou sobre bexiga hiperativa.

"Incontinência urinária é perder urina (...) aí, por exemplo, você espirra e você perde... você faz muita força, você perde... é isso... ou alguma gotinha, fica perdendo..." (P12, 18, IU)

"Eu sei que tem três tipos de incontinência urinária, não lembro o nome... de esforço (...) A de esforço eu acho que é se você espirrar, se você tossir, eu acho que é uma que 
você não consegue controlar. Depois tem a de urgência, então a de urgência acho que não consegue controlar nada. (...) E a mista são as duas né. Mas eu acho que elas são bem interligadas né, todas acabam sendo bem complicadas." (P8, 39)

"A incontinência urinária é quando você não consegue segurar e tem o leve, ai só lembro do leve... moderado...e grave." (P14, 54, IU, DS)

"Moderado, né? Tem grau 1, 2 e vai aumentando os graus de acordo com a perda de musculatura, de acordo com, assim, a intensidade, necessidade de urinar né que é a urgência, emergência, aquela urina que você perde... está sempre perdendo um pouquinho. Então de acordo com a perda elas vão dando o grau, aquele grau que a bexiga já fica exposta né, as vezes até sai para fora, não sei se é grau 5 ou 4, mas é isso aí." (P15, 54, IU, IA)

"Que tem vez que ela acha que ta cheia e não ta, ela quer que você vá toda hora." (P5, $46, \mathrm{IU}, \mathrm{DS})$

A etiologia de disfunções do AP mais lembrada foi a da IU, mencionada por 12 participantes. Os fatores de risco pontuados foram obesidade, esforço contínuo, constipação intestinal, gravidez, número de partos normais, histórico de partos instrumentalizados, infecção, fraqueza dos MAP, fatores psicológicos e postura. Apenas duas participantes lembraram dos alimentos irritativos da bexiga.

“Obesidade porque serviu pra mim né, então gravei. É, obesidade, não lembro mais. Acho que parto também, mas o que mais me gravou que quando você engorda muito né, o peso..." (P5, 46, IU, DS)

"Falou assim, que o intestino preso, conforme você vai no banheiro, força e vai laceando aquele músculo..." (P6, 70, IU, C)

"É aquela perda de urina involuntária, que você perde urina sem querer. Por mais que você tente não perder, ela está saindo, tá descendo.... e seria a falta de fortalecimento dos músculos... causado pela idade, por várias coisas... É causado pela idade, pela quantidade de partos que já teve, partos normais também, né... enfraquecimento dos músculos e ter excesso de peso, e o peso que a mulher pega também pode causar né... isso aí..." (P13, 66, IU, POP)

“A questão de tomar bastante água também foi muito falado né, pra tomar... não tomar muito suco, frutas cítricas, café que tem a cafeína, refrigerante também evitar. Não é que precisa para lá no zero, mas assim reduzir ao máximo porque tudo isso pode ajudar na irritação da bexiga" (P13, 66, IU, POP) 
Nove participantes lembraram algo relacionado a etiologia do prolapso dos órgãos pélvicos. Os fatores de risco para POP mencionados foram fraqueza dos MAP, gravidez, histórico de parto normal ou não, número de partos, esforço, histórico de cirurgias e constipação. Três participantes lembraram que há estadiamentos para indicativo de progressão da disfunção.

"O que poderia acontecer se os músculos estivessem fracos, que poderia sair, que sai para fora a bexiga." (P1, 44, IU, DS)

“A pior fase é quando ela sai assim né, pra fora, essa é a pior.” (P5, 46, IU, DS)

"Dependendo de como ela cai chega até a aparecer no canal vaginal, não que ela apareça, mas ela empurra a musculatura e é isso pelo que eu lembro, que conforme ela abaixa, dependendo do grau que ela chega, ela chega até ficar aparecendo a musculatura mesmo, que ela pesa né e aí os fatores são esses, o parto, um esforço, às vezes alguma cirurgia que foi feita e danificou essa musculatura e ela não consegue mais dar essa sustentação." (P8, 39)

"É através de... acredito que assim... através da, do parto, que a bexiga saiu, ou do intestino preso, de fazer muita força... aí vai forçando..." (P11,67, IU)

Seis participantes mencionaram algumas causas das DS femininas. Foram consideradas causas das DS infecção urinária, alteração hormonal, fraqueza dos MAP, falta de preliminares ou lubrificação, endometriose e estar na menopausa foi mencionada uma vez cada.

"É, foi falado que várias mulheres tem esse incomodo, né... na penetração... tudo isso, eu presumo que seria o enfraquecimento dos músculos que gera isso aí... eu não lembro exatamente as palavras que foram usadas, mas o enfraquecimento desses músculos aí causa, como causa a incontinência, o problema no intestino, também pode causar na relação... causando dor, incomodo..." (P13, 66, IU, POP)

"Ah o que eu lembro é isso, se sente dor durante o ato, na penetração, também muito depende do parceiro, como a gente diz mais popular, nas preliminares, do ambiente, elas falaram tudo isso." (P15, 54, IU, IA)

“É, ressecamento... depois da menopausa" (P17, 67, C, DS) 
Em relação as disfunções de compartimento posterior, seis participantes lembraram o que é incontinência anal ou que a fraqueza dos músculos do assoalho pélvico é sua principal causa como pode ser observado nos fragmentos abaixo. Apenas três participantes lembraram algo relacionada a constipação intestinal.

"Eu acho que por causa da flacidez [dos músculos do assoalho pélvico] também" (P19, 69, IU, IA, C, DS)

"Então pelo que eu entendi é relacionado também com a musculatura, assim como tem a musculatura pélvica ali tem a musculatura do ânus, do reto, então também o que pode causar é a perda da musculatura.” (P15, 54, IU, IA)

“Quando você é mais nova você consegue segurar, dá tempo de chegar no banheiro... agora uma pessoa de idade já não consegue, porque ta mais relaxado... os músculos né. Até tentam, coitados, mas..." (P1, 44, IU, DS)

"Perda de fezes involuntária também... e aquela também, o intestino preso que fala né? intestino preso é aquela pessoa que não consegue ir no banheiro todos os dias." (P13, 66, IU, POP)

"Eu não sabia que tinha a ver também, aí eu lembro que a pessoa que tem esse problema teria constipação por uma falta de controle da musculatura pélvica, não é isso? [fala pausada]" (P3, 40, IU, POP)

\subsubsection{Tratamento das disfunções do assoalho pélvico}

O nível de conhecimento desenvolvido pelas participantes com e/ou prévio ao grupo educativo sobre as opções de tratamento das disfunções do AP foi esparso. Em relação a avaliação fisioterapêutica, apenas dez participantes lembraram algum aspecto da mesma. Uma relatou o processo de educação em saúde que ocorre no começo da avaliação, duas sobre a anamnese e sete sobre o exame físico. $\mathrm{O}$ exame físico foi relatado com termos como toque, exame ginecológico, palpação e/ou "colocar o dedo". Uma participante relatou que a avaliação fisioterapêutica consiste de aprender a respiração.

"Foi comentado que teria que, eu não sei se é para fazer a fisioterapia, que teria que passar por um exame tipo o exame ginecológico" (P1, 44, IU, DS) 
"É toque né? Tem que ser um toque que não tem outro jeito, tem que ser, isso é certeza. O que mais me gravou foi que realmente você tem que tocar pra ver, para saber..." (P5, 46, IU, DS)

"Então, a avaliação feita no primeiro dia assim, que é o questionário, pergunta... e é feita a palpação né, faz a avaliação com a palpação pra medir a força que nó temos ali na contração vaginal,ai a partir dessa avaliação, é que vai fazer o tratamento conforme a necessidade da mulher, os aparelhos, usar os aparelhinhos né.” (P13, 66, IU, POP)

“Ah, aprender a respiração, não?” (P10, 78, IA)

Apenas nove participantes lembraram algum aspecto do tratamento fisioterapêutico para disfunções do assoalho pélvico. Duas participantes comentaram sobre o treinamento vesical, oito sobre o fortalecimento dos MAP e duas sobre a possibilidade do uso complementar de equipamentos.

"Não, [expressão facial de perplexidade] acho que sobre como era a fisioterapia em si não. Foi comentado que teria que, eu não sei se é para fazer a fisioterapia, que teria que passar por um exame tipo o exame ginecológico mas assim... Mas assim, como seria a fisioterapia em si, não. Eu não lembro. Só comentou sobre esse exame." (P1, 44 , IU, DS)

"Mas ai você tem que trabalhar a vontade ou é a bexiga que tá preguiçosa também né?! Que tem vez que ela acha que ta cheia e não ta, ela quer que você vá toda hora e você vai ter que controlar um pouquinho pra aprender a controlar ela, né?! [se referindo treinamento vesical]" (P5, 46, IU, DS)

"Olha eu não sei falar os termos técnicos, mas eu sei que tem os exercícios e dependendo do grau tem os aparelhos que vai trabalhar essas musculaturas tentando melhorar essa musculatura." (P8, 39)

Nove participantes souberam elencar pelo menos um motivo para se realizar o TMAP, sendo considerado importante para "evitar que tudo fique despencado", melhorar qualidade de vida, para prevenir ou tratar incontinência urinária e/ou anal e/ou POP, fortalecer os MAP e criar sensibilidade/ consciência do períneo.

"Porque sem os exercícios você vai vendo o que vai causando, você não utiliza. A gente vê que vai descendo, pode descer os órgãos e com o exercício você exercita a musculatura e consegue segurar. Então assim, melhora muita coisa." (P16, 42, IU, C, DS) 
"viu que gostoso você sentir que tem uma coisa que tá morta ali, escondida, esse aí vai te animar bastante ó, faz mesmo que você não tem problema mas faz". (P7, 65, IU, C, POP)

Duas mulheres relataram compreender que tratamento fisioterapêutico é realizado em estágios iniciais de POP e a opção terapêutica para estágios mais avançados é a cirurgia. Enquanto seis mulheres relataram que o tratamento da constipação intestinal é com melhora da ingestão hídrica, adequação alimentar e realizar exercício físico. Apoiar os pés no banquinho durante a evacuação e realizar massagem abdominal foram mencionados por apenas uma participante cada.

"A isso ai eu acho que é, isso assim é só cirurgia. Nesse caso ai é só cirurgia, não tem... Agora quando é no começo tem tratamentos, e esses exercícios ajudam de monte, bastante." (P5, 46, IU, DS)

"Então tem os exercícios né e para um caso mais grave é cirúrgico mesmo né, mas até então a gente pode prevenir para não estar agravando.” (P14, 54, IU, DS)

“Alimentação, eu sei que tem tudo a ver. Fazer algum exercício também é importante. Exercitar, subir escada, descer, fazer caminhada, uma natação. Ele falou sobre exercícios que eu lembro. A água né, que eu já comentei. (Pausa) Não to lembrando mais não.” (P5, 46, IU, DS)

"O intestino preso é que tem que fazer a massagem e tem que comer muitas coisas pra ajudar, depende do alimento que você come, depende da comida que você come. Se você come a comida corrida vai tá com intestino preso, se você come o certo ai o seu intestino vai funcionar todos os dias." (P18, 48 IU, C, DS)

"Ah, aprendi sobre aqueles exercícios né. E aquele um também cê senta no vaso sanitário e levanta a perna. Muito bom também. Aquele um que você senta e cê levanta perna para não forçar muito o assoalho pélvico na hora de fazer cocô" (P6, 70, IU, C)

Em relação ao profissional escolhido pelas participantes como referência para buscar tratamento para disfunções do AP, o fisioterapeuta foi citado quatro vezes, o ginecologista seis, o clínico geral e geriatra foram mencionados uma vez cada. Das seis mulheres que mencionaram o ginecologista como profissional de referência para tratar disfunções do AP, duas o usariam como forma de chegar ao tratamento fisioterapêutico. 
"O fisioterapeuta, né?! A gente procura primeiro o GO pra depois ser encaminhada para o fisioterapeuta.” (P18, 48, IU, C, DS)

"Eu acho que é o GO, mas não só ele, primeiro acho que é o clínico geral, no meu caso hoje não é mais ele, é o geriatra né, o geriatra para mim foi uma benção do céu na minha vida." (P7, 65, IU, C, POP)

"Fisioterapeuta, primeiro." (P3, 40, IU, POP)

\subsubsection{Treinamento dos músculos do assoalho pélvico}

Das 19 entrevistadas, 14 lembraram como fazer o TMAP durante alguma das três entrevistas. A descrição mais comumente utilizada foi o "segura e solta", apenas quatro participantes lembraram do protocolo de exercícios, cinco sobre a necessidade de treinar em diferentes posições e quatro sobre a importância de manter a respiração normal durante o TMAP. Somente quatro participantes tiveram fragmentos textuais selecionados em mais de um timepoint.

"O único que eu lembro é aquele que [gestos de abrir e fechar a mão] que prende e solta." (P2, 54, IU, C, DS)

"No caso, de contração dos músculos para fortalecer eles, aí tem exercício em pé, sentado, em quatro apoios, deitado, tudo onde trabalha a musculatura, aí você faz as contrações, segura por alguns segundos, relaxa... E aí uma questão importante é a respiração, você não prender a respiração junto, fazer a coisa (exercício) e respirar normalmente.” (P8, 39)

"Mandou vários exercícios: sentada né, contar 1,2,3 até 6, 10 vezes. Mandou fazer esse exercício sentado, mandou fazer em pé, mandou fazer... Segurar, contrair né? O músculo né, contar 1,2,3,4,5,6... fazer 6 vezes, todos eles." (P9,61, IU)

"Contração, solta. Ai eu não lembro quanto tempo, quantas vezes, não lembro não." (P14, 59, IU, DS) 


\subsection{TEMA 3 - MUDANÇA EM HÁBITOS DE VIDA APÓS PARTICIPAÇÃO EM GRUPO EDUCATIVO}

Esse tema trás os relatos das mudanças realizadas no dia-a-dia das mulheres que participaram do grupo educativo, assim como fatores que facilitaram e dificultaram a adesão às mesmas. Apresentação dos relatos de mudanças nos sintomas de disfunção do AP com a adesão às orientações oferecidas durante o grupo, em especial ao TMAP.

\subsubsection{O que mudou?}

A adesão às orientações oferecidas durante o grupo educativo é o objetivo central do mesmo. Uma semana após o grupo, 17 participantes relataram ter tentado realizar o TMAP em casa pelo menos uma vez na última semana e oito relataram ter feito alguma outra modificação em seus hábitos de vida. A massagem abdominal foi realizada por três participantes na última semana, duas que adequaram a ingestão hídrica e duas fizeram adequação da frequência miccional. Elevação dos membros inferiores durante a evacuação, interrupção do uso de medicamentos sem orientação médica, uso de estratégias de inibição da urgência urinária, realização da respiração diafragmática, redução do consumo de alimentos irritativos para a bexiga e uso do banquinho para apoiar os pés durante a defecação foram relatados uma única vez cada.

"Não faço não. Esqueço de fazer. Só de vez em quando, quando eu lembro que começo a contrair. Só quando eu lembro que eu contraio." (P2, 54, IU, C, DS)

"Eu faço umas quatro, cinco vezes. Se eu to sentada e eu lembro, eu faço, se eu tô em pé eu lembro e faço. Antes de levantar eu faço aquele encima da cama. É assim, seis vezes devagar e seis vezes rápido. Todos que eu lembro, que foi dado e que eu entendi bem, eu faço.” (P7, 65, IU, C, POP)

"Eu percebi, eu até fiz uma... como fala.. um seguimento aqui em uma planilha [diário miccional] só que eu percebi que depende da ingestão de líquidos né. Então nessa planilha eu percebi que eu não to ingerindo muito líquido. Tipo, água só de manhã e à noite, só que eu não estava percebendo que não tava bebendo água né. $\mathrm{E}$ aí depois que eu fiz a planilha que eu percebi que não tava bebendo 
água aí eu comecei a tomar mais água. Mas não tá aqui, depois que eu comecei a tomar água." (P3, 40, IU, POP)

"[risos] ai ai, eu levando assim minha perna [indicando que segura os joelhos, deixando os pés no ar] mas não coloco no banquinho não..." (P6, 70, IU, C)

"Então através daqui eu comecei a me policiar mais, observar como que tava sendo meu xixi, inclusive eu tenho um pouquinho de ressecamento do intestino e a massagem que os meninos ensinaram foi pra mim ótimo, de pôr o pé no banquinho.” (P19, 69, IU, IA, C, DS)

Três meses após o grupo, 13 participantes relataram ter tentado realizar o TMAP em casa pelo menos uma vez na última semana e sete relataram ter feito alguma outra modificação em seus hábitos de vida. Aumento da ingestão hídrica foi mencionado por três participantes, inicio da prática de exercício físico, adequação alimentar, uso de estratégias de inibição de urgência e busca por tratamento médico foi relatada por uma participante cada. Uma participante relatou que passou a se valorizar mais.

"Continuei fazendo os exercícios, tem aqui o papel ainda né, eu vou e faço." (P11, 67, IU)

"Eu tenho feito de acordo aqueles exercícios que vocês deram, aqueles papelzinho, eu procuro fazer só que é o que eu tô te falando, eu procuro assim contrair a musculatura sabe? Eu não sei. Tem semana que eu faço duas, tem semana que faço três. Ás vezes eu pulo um dia, faço quase todos os dias, mas eu não tenho deixado de fazer não." (P19, 69, IU, IA, C, DS)

“Tomo bastante líquido, mais do que antes.” (P4,63, IU)

"Então, eu tô gostando mais de mim. Eu me afastei tipo assim... diz que obesidade tem a ver, deu um alerta pra minha vida, eu tô fazendo caminhada, tirei da minha vida gordura, fritura eu não vou falar que tirei 100\% mas eu tirei uns 40\%." (P5, 46, IU, DS)

"Eu tive mais crescimento, mais conhecimento com a vida, aprendendo a valorizar mais aquilo que a gente tem que a gente não sabe e que a gente pode melhorar se você tem boa vontade." (P7, 65, IU, C, POP)

Em um intervalo de cinco a 16 meses após o grupo, três participantes relataram ter tentado realizar o TMAP em casa pelo menos uma vez na última semana e quatro relataram ter feito alguma outra modificação em seus hábitos de vida. O perfil das mudanças em 
hábitos de vida foi diferente relatada foi diferente das entrevistas anteriores, três mulheres relataram que passaram a se valorizar mais e uma que criou uma melhor percepção corporal e conseguiu falar mais sobre seus sintomas. Apenas uma participante relatou estar usando as estratégias de inibição de urgência.

"Não faço todo dia. Ah eu faço poucas vezes [na semana]... eu faço umas 3 ou 4 só." (P6, 70, IU, C)

“Assim, eu faço só quando eu lembro (...) Esses dias mesmo eu fiz duas vezes.. (P18, $48, \mathrm{IU}, \mathrm{C}, \mathrm{DS})$

"Eu comecei a olhar mais para essa minha região, com outros olhos, né? Aliás com outra mente. Comecei a olhar mais, assim, pensar que eu tenho essa parte do corpo, porque eu tenho que fazer funcionar, né?" (P3, 40, IU, POP)

"Eu acordo e sinto que se eu levantar e for lá tem, mas eu vou tentar dormir, seguro, seguro até esquecer e durmo, não levanto." (P7, 65, IU, C, POP)

\subsubsection{Como faz o treinamento dos músculos do assoalho pélvico em casa?}

Independente do tempo de entrevista após o grupo educativo, podemos observar que há uma enorme variação nos protocolos de treinamento que as participantes realizam em casa. O número de contrações rápidas variou de 6 a 10, 10 contrações sustentadas de 6 a 20 segundos, com uma frequência diária de 1 a 3 vezes e frequência semanal de 3 vezes. $\mathrm{O}$ TMAP foi realizado durante a ponte, em pé, sentada, deitada, de quatro apoios associados ou não a atividades de vida diária. Entretanto podemos observar nos relatos que a maior parte das mulheres realizam o TMAP quando lembrava e sustentava por quanto tempo conseguisse. Cabe destacar que o stop test, realizar elevação de quadril, alongamento de tríceps sural e respiração diafragmática foram mencionados por uma participante cada como forma de fortalecer os MAP.

Fragmentos das entrevistas de uma semana após a participação no grupo educativo: 
"As vezes quando estou lavando na cozinha ou lavando roupa, as vezes eu fico [gestos de abrir e fechar a mão] contraindo. Eu gosto de ficar contraindo, eu lembro, aí eu fico [gestos de abrir e fechar a mão]. Quando eu lembro eu contraio.” (P2, 54, IU, C, DS)

"No meu caso, eu estou tendo que começar devagar, eu não consigo fazer todas as repetições ainda porque parece que fica cansativo, a musculatura fica cansada, não sei se é isso mesmo, mas não é uma coisa que dá para fazer tudo de uma vez e olha que a minha musculatura está forte, não é cinco mas é quatro...” $(\mathrm{P} 8,39)$

"[sobre o stop test] $\mathrm{Eu}$ faço todo dia, principalmente a noite, quando eu vou ao banheiro, a noite eu tento fazer. (...) eu solto ele [urina] depois, eu faço sim, seguro umas duas vezes e depois solto." (P15, 54, IU, IA)

"Eu faço todos os dias, ao levantar, pelo menos três... se não dá mais pelo menos três vezes eu faço, isso eu faço todos os dias. Mesmo antes de saber a importância eu já... não fazia assim profundo... mas eu tenho esse de fazer todos os dias. [fala confusa] (...) É. Eu sempre, tipo assim, como "'saudar o dia", mas puxando uma respiração, segurando, sabe? Isso eu tenho mania de fazer" (P4, 63, IU)

"Faço mais é de manhã... mas só uma vez deitada e uma vez em pé... (...) Oh, eu faço deita, boto as duas mãos uma de cada lado e levando o bumbum né [indicando que faz elevação de quadril] e seguro por 10 vezes, respiro uma e seguro, aí depois eu vou soltando por 12 vezes. Aí isso eu faço por cinco vezes... aí em pé eu seguro assim na parte do guarda-roupa e contraio, só que aí eu conto 50 vezes [indicando alongamento de triceps sural]." (P6, 70, IU, C)

Fragmentos das entrevistas de três meses após a participação no grupo educativo:

"Só faço uma. Eu faço assim... deitada né, ponho a mão assim [bracos extendidos ao lado do corpo], levanto bumbum e conto 10x, retrai né. A musculatura lá embaixo. Conto 10x, depois eu solto conto 12x, eu faço isso umas 10x.” (P6, 70, IU, C)

"Fala pra fazer 3x na semana tal então eu faço 10 por dia de cada jeito, 10 rapidinho, 10 depressa. Eu conto 10x porque eu lembro que foi falado 10x. Você fecha assim, segura e depois relaxa, certo? Segura, relaxa. 10x bem devagar, depois 10x depressa, segura e solta, segura e solta, entendeu? Deu pra entender? É assim? (...) Todo dia eu faço esse. Eu faço aquele do cachorro, duas mãos, dois pés lá atrás, sobe, a mesma coisa né. Ai esse às vezes eu faço umas 30x até que as mãos aguenta." (P7, 65, IU, C, POP)

"O que eu mais faço é o de respirar, segurar e soltar." (P4,63, IU)

"Ai uma vez por dia quando eu vou fazer xixi, não o primeiro xixi, independente de horário e de qual xixi seja, eu seguro. Eu corto, dou uma seguradinha, aí depois eu solto. Corto umas três vezes durante uma micção que eu vou e paro." (P15, 54, IU, IA) 
Fragmentos das entrevistas de cinco à 16 meses após a participação no grupo educativo:

"Mais o que eu faço é em pé. Aquele de segurar e soltar. Tem que puxar né. E solta. Eu faço 3, 4, mais vezes. Segura... [indica contração abdominal, simulando uma respiração diafragmática] Puxo, seguro, aí solto e conto né. Conto até 10.” (P4, 63, IU)

“1, 2, 3, depois descansa... 6..." conto tanto na hora que tá fazendo quanto na hora de descansar, e faz umas 8 vezes, é depende do dia que tá e a hora, mas é umas 8 vezes mais ou menos que eu repito, todos eles né, tanto o gato quanto o sentado né... você tá fazendo e $1,2,3,4,5,6$ e solta, $1,2,3,4,5,6$, volta... é assim que eu trabalho né, a musculação." (P7, 65, IU, C, POP)

\subsubsection{O que facilitou aderir às orientações do grupo educativo?}

Os fatores que facilitaram as mulheres a aderirem as orientações do grupo educativo, em especial realizar o TMAP domiciliar, variaram ao longo das três entrevistas. $\mathrm{O}$ fato das mulheres estarem ou não seguindo as orientações também foi considerado na distribuição dos facilitadores.

Das 19 mulheres que participaram da primeira entrevista, 11 relataram estar aderindo às orientações conforme informado no grupo educativo, seis mulheres relataram estar aderindo às orientações, mas não como informado e duas não estavam seguindo nenhuma da orientação. Para o primeiro grupo de mulheres, a cartilha com os exercícios, o atendimento fisioterapêutico, associar a atividades de vida diária (AVDs), as informações obtidas no grupo educativo, o querer melhorar dos sintomas de disfunções de AP e se organizar para realizar o TMAP funcionaram como facilitadores. Para o segundo grupo de mulheres, a cartilha e as informações obtidas com o grupo também apareceram como facilitadores assim como o uso de lembretes (despertador no celular) e o apoio familiar. Já para o terceiro grupo, apenas realizar mais prática do TMAP no grupo educativo poderia facilitar para que elas fizessem os exercícios em casa. Na tabela (Tabela 12) abaixo é possível visualizar fragmentos ilustrativos dos facilitadores para aderir as orientações do grupo educativo indicados pelas participantes que participaram da primeira entrevista. 
Tabela 12 - Apresentação dos facilitadores para a modificação de hábitos de vida identificados por 19 participantes, uma semana após o grupo educativo

\begin{tabular}{|c|c|c|}
\hline Facilitador & $\begin{array}{l}\text { Número de } \\
\text { menções }\end{array}$ & Exemplo \\
\hline Grupo educativo & 6 & $\begin{array}{l}\text { "Porque, tipo assim, ela [se referindo a fisioterapeuta que a atende] falava assim } \\
\text { "ah tem que fazer o exercício em casa" mas eu "ah, pra que...” [murmurando } \\
\text { dando a entender insatisfação com a orientação da fisioterapeuta], só que quando } \\
\text { eles explicaram eu entendi porque que eu tenho que fazer todo o dia, entendeu? aí } \\
\text { eu comecei a fazer... porque eu ví a importância... o que que acontece lá..." (P12, } \\
18, \mathrm{IU}) \\
\text { "Eu não tinha essa noção e agora eu tenho. Então aí a gente começa a dar um } \\
\text { pouquinho mais valor à nossa região pélvica, trabalhar toda a musculatura pra dar } \\
\text { sensibilidade tanto anal quanto vaginal. E isso." (P16, 42, IU, C, DS) }\end{array}$ \\
\hline Querer melhorar & 4 & $\begin{array}{r}\text { "Saber que é pra saúde da gente, então a gente tem aquela vontade de fazer, sente } \\
\text { necessidade de fazer." (V9,61,IU) } \\
\text { "Facilitou pelo lado bom, que melhorou." (P19, 69, IU, IA, C, DS) }\end{array}$ \\
\hline Cartilha & 4 & $\begin{array}{r}\text { "Eu até coloquei a planilha que eles deram lá com todas as informações do lado da } \\
\text { minha cama, porque eu falei assim "eu preciso fazer né, antes que as coisas ficam } \\
\text { piores", mas eu não lembro." (P1, 44, IU, DS) } \\
\text { "Aí, quer ver. Eu fiz sentada na cadeira, deitada, traz o joelho para cima... daquela } \\
\text { figura que estava no cartão [folheto] (...)" (P11,67, IU) }\end{array}$ \\
\hline Associar a AVDs & 2 & $\begin{array}{l}\text { "Eu quero tentar melhorar isso mais. Quero ter esse hábito de fazer, não vou } \\
\text { prometer todos os dias mas de repente você está deitada, está lendo um livro, então } \\
\text { tentar conciliar com... eu tô aqui conversando com você... sabe, criar um hábito } \\
\text { porque é uma coisa que não atrapalha em nada, mas ter esse hábito." (P8, 39) }\end{array}$ \\
\hline Organizar & 2 & $\begin{array}{l}\text { "Ai depois você vê a importância, você começa a querer "esse horário eu vou tirar } \\
\text { pra fazer isso, esse tipo de exercício.." (P16, 42, IU, C, DS) }\end{array}$ \\
\hline Uso de lembretes & 1 & $\begin{array}{r}\text { "Acho que vou pô no meu celular "hora do exercício" e ir lá e perder uns } \\
\text { minutinhos..." (P1, 44, IU, DS) }\end{array}$ \\
\hline $\begin{array}{l}\text { Mais prática no } \\
\text { grupo }\end{array}$ & 1 & $\begin{array}{l}\text { "Também acho que mais prática a gente vai sair daqui mais informada para você } \\
\text { praticar o exercício no dia-a-dia, eu acho importante ter mais prática também." } \\
(\mathrm{P} 15,54, \mathrm{IU}, \mathrm{IA})\end{array}$ \\
\hline Apoio familiar & 1 & $\begin{array}{l}\text { “(..) que nem minha filha mesmo: "mãe você tá fazendo os exercícios? Mãe você } \\
\text { tá fazendo os exerícios? Você não tá fazendo né? Você tá com preguiça, não faz"." } \\
(\mathrm{P} 18,48 \mathrm{IU}, \mathrm{C}, \mathrm{DS})\end{array}$ \\
\hline $\begin{array}{l}\text { Acompanhamento } \\
\text { fisioterapêutico }\end{array}$ & 1 & $\begin{array}{l}\text { "[sobre participar do grupo durante o tratamento fisioterapéutico] Ficou mais fácil. } \\
\text { Você tá ouvindo e você tá sendo tocada com as mãos naquilo, então ajuda bastante. } \\
\text { Pra quem presta atenção ajuda muito." (P7, 65, IU, C, POP) }\end{array}$ \\
\hline
\end{tabular}

$\mathrm{AVDs}=$ atividades de vida diária; $\mathrm{P}=$ participante; $\mathrm{IU}=$ incontinência urinária; $\mathrm{IA}=$ incontinência anal; $\mathrm{C}=$ constipação; $\mathrm{DS}=$ disfunção sexual; $\mathrm{POP}=$ prolapso dos órgãos pélvicos

Das 14 mulheres que participaram da segunda entrevista, oito relataram estar aderindo às orientações conforme informado no grupo educativo, quatro mulheres relataram estar aderindo às orientações, mas não como informado e uma não estavam seguindo nenhuma da orientação. Para o primeiro grupo de mulheres, a cartilha com os exercícios, fazer os exercícios como lembra, associar AVDs, o querer melhorar dos sintomas de 
disfunções de AP, as informações obtidas no grupo educativo, se organizar para realizar o TMAP e ter mais prática do exercício no grupo educativo funcionaram como facilitadores. Para o segundo grupo de mulheres, associar o TMAP a AVDs, querer melhorar dos sintomas de disfunções do AP, se organizar ou usar lembretes, as informações obtidas com o grupo e ter o acompanhamento fisioterapêutico apareceram como facilitadores. Já para o terceiro grupo, apenas a cartilha e fazer os exercícios como lembra poderia facilitar para que ela fizesse os exercícios em casa. Na tabela 13 é possível visualizar fragmentos ilustrativos dos facilitadores para aderir as orientações do grupo educativo indicados pelas participantes que participaram da segunda entrevista.

Tabela 13 - Apresentação dos facilitadores para a modificação de hábitos de vida identificados por 14 participantes, três meses após o grupo educativo

\begin{tabular}{|c|c|c|}
\hline Facilitador & $\begin{array}{l}\text { Número de } \\
\text { menções }\end{array}$ & Exemplo \\
\hline Associar a AVDs & 6 & $\begin{array}{r}\text { "A hora que eu vou deitar, que eu deito na cama parece que é a hora que eu mais } \\
\text { lembro." (P5, 46, IU, DS) } \\
\text { "As vezes quando eu tô em pé que eu lembro né, na pia ou lavando uma roupa dá } \\
\text { pra fazer um pouco daí faz e nem conto, vou fazendo." (P7, 65, IU, C, POP) } \\
\text { "Eu faço de manhã a hora que eu acordo, antes de levantar que ai já tenho aquele } \\
\text { horário pra levantar." (P7, 65, IU, C, POP) }\end{array}$ \\
\hline Grupo educativo & 5 & $\begin{array}{r}\text { "Então, as vezes faltava o aprendizado mesmo, o saber." (P4,63, IU) } \\
\text { "Por que eu tenho essa consciência? Porque o curso que eu fiz me trouxe essa } \\
\text { visão, da necessidade desse fortalecimento" (P8, 39) }\end{array}$ \\
\hline $\begin{array}{l}\text { Querer ou sentir } \\
\text { que melhorou }\end{array}$ & 4 & $\begin{array}{l}\text { "Por necessidade né, sei que é preciso, é pro bem-estar da gente né." (P9, 61, IU) } \\
\text { "Porque eu senti melhoria né. Eu senti melhoria pra mim." (P18, 48, IU, C, DS) }\end{array}$ \\
\hline Organizar & 3 & $\begin{array}{r}\text { "O dia da semana que eu tirei pra isso, ai eu vou e faço, achei mais fácil porque } \\
\text { um pouco daqueles exercícios eu faço no "pic" [grupo de exercícios para a } \\
\text { terceira idade] também." (P11, 67, IU) }\end{array}$ \\
\hline Cartilha & 2 & "Ah, eu achei bem mais fácil sim. Aquele da figura, do papel." (P11, 67, IU) \\
\hline Fazer como lembra & 2 & $\begin{array}{l}\text { "Se puder fazer assim sem ter que ficar contando acho que seria mais fácil porque } \\
\text { aí você tá ali você lembrou você já..." (P1, 44, IU, DS) }\end{array}$ \\
\hline Uso de lembretes & 1 & “Passa uma dica. Dá um sinalzinho no telefone." (P17, 67, C, DS) \\
\hline $\begin{array}{l}\text { Mais prática no } \\
\text { grupo }\end{array}$ & 1 & $\begin{array}{l}\text { "Eu acho que poderia ter tido um pouco mais de treinamento. Se tivesse um } \\
\text { pouquinho mais de treinamento assim acho que a gente pegava melhor né, a1 } \\
\text { tinha menos preguiça de fazer." (P15, 54, IU, IA) }\end{array}$ \\
\hline $\begin{array}{l}\text { Acompanhamento } \\
\text { fisioterapêutico }\end{array}$ & 1 & $\begin{array}{r}\text { "Porque assim quando você faz o tratamento acho que você fica mais na } \\
\text { obrigação de fazer aquela ginástica né?" (P14, 59, IU, DS) }\end{array}$ \\
\hline
\end{tabular}


Das nove mulheres que participaram da terceira entrevista, quatro relataram estar aderindo às orientações conforme informado no grupo educativo, duas relataram estar aderindo às orientações, mas não como informado e três não estavam seguindo nenhuma da orientação. Para o primeiro grupo de mulheres, a cartilha com os exercícios, associar a AVDs, as informações obtidas no grupo educativo, o querer melhorar ou ter melhorado dos sintomas de disfunções de AP e se organizar para realizar o TMAP funcionaram como facilitadores. Para o segundo grupo de mulheres, associar a AVDs, as informações obtidas no grupo educativo, o querer melhorar ou ter melhorado dos sintomas de disfunções de AP e se organizar para realizar o TMAP também foram considerados facilitadores para aderir ao TMAP assim como uso de lembretes audiovisuais. Para uma participantes sem sintomas de disfunções do AP, ouvir os relatos sobre como é ter disfunções do AP a motivou a tentar fazer o TMAP em casa. Já para o terceiro grupo, ter acompanhamento fisioterapêutico, se organizarem melhor, uso de lembretes audiovisuais e acompanhamento de blogs poderiam facilitar para que elas realizassem os exercícios em casa. Na tabela 14 é possível visualizar fragmentos ilustrativos dos facilitadores para aderir as orientações do grupo educativo indicados pelas participantes que participaram da terceira entrevista.

Tabela 14 - Apresentação dos facilitadores para a modificação de hábitos de vida identificados por nove participantes em um intervalo de cinco a dezesseis meses após o grupo educativo

\begin{tabular}{|c|c|c|}
\hline Facilitador & $\begin{array}{l}\text { Número de } \\
\text { menções }\end{array}$ & Exemplo \\
\hline Associar a AVDs & 6 & $\begin{array}{r}\text { "Não é parar, par pra fazer isso, né? Por exemplo, to aqui mesmo senta da e } \\
\text { já faço assim ó [simula estar fazendo TMAP].” (P17, 67, C, DS) } \\
\text { "Esse sentado às vezes eu to comendo, eu lembro, eu faço, às vezes eu tô no } \\
\text { ônibus e se não tem ninguém perto... se não vai falar que eu tô louca. O em } \\
\text { pé, na hora que tá na cozinha, na hora que tá passando roupa, faz." (P7, 65, } \\
\text { IU, C, POP) } \\
\text { "Ela fala que ela faz esse exercício caminhando." (P6, 70, IU, C) }\end{array}$ \\
\hline Uso de lembretes & 3 & $\begin{array}{r}\text { "Eu acho que a gente deveria espalhar bilhete, tem que espalhar, porque se } \\
\text { não não lembra mesmo." (P1, 44, IU, DS) } \\
\text { "Colocar o celular para despertar." (P17, 67, C, DS) }\end{array}$ \\
\hline Grupo educativo & 2 & $\begin{array}{r}\text { "Eu tenho essa consciência! Pelo menos a conscientização foi trabalhada." } \\
\text { (P8, 39) } \\
\text { "A orientação é muito importante." (P19,69, IU, IA C, DS) }\end{array}$ \\
\hline $\begin{array}{l}\text { Querer ou sentir que } \\
\text { melhorou }\end{array}$ & 2 & "É porque eu sinto que vai melhorar cada dia mais.." (P18, 48,IU, C, DS) \\
\hline Organizar & 2 & "Tem que ser uma rotina, né? Aquilo torna um habito, da gente pegar aquilo \\
\hline
\end{tabular}




\begin{tabular}{|c|c|c|}
\hline & & como um habito e levar a sério que dá certo." (P19,69, IU, IA C, DS) \\
\hline Cartilha & 2 & $\begin{array}{r}\text { "Ajuda! [cartilha] Mostra os exercícios que a gente pode fazer.” (P18, 48,IU, } \\
\text { C, DS) }\end{array}$ \\
\hline $\begin{array}{l}\text { Acompanhamento } \\
\text { fisioterapêutico }\end{array}$ & 1 & $\begin{array}{l}\text { "Então, assim, como eu tava fazendo fisioterapia é.. eu fui acostumando né? } \\
\text { Então, assim, aquilo que fazia em casa também e tal." (P3, 40, IU, POP) }\end{array}$ \\
\hline $\begin{array}{l}\text { Ouvir relatos de } \\
\text { disfunções do AP }\end{array}$ & 1 & $\begin{array}{r}\text { "Pra daqui a alguns anos, quando a gente vai adquirindo mais idade, não } \\
\text { tenha esse problema desconfortável, né?! Igual ela passou [se referindo } \\
\text { sobre a colega]" }(\mathrm{P} 8,39)\end{array}$ \\
\hline Blogs & 1 & $\begin{array}{c}\text { "Eu comecei a seguir a [nome da blogueira]. Aí eu ficava direto vendo os } \\
\text { vídeos dela e fazendo os exercícios e tal." (P3, 40, IU, POP) }\end{array}$ \\
\hline
\end{tabular}

5.5.4. O que dificultou aderir às orientações do grupo educativo?

Assim como os facilitadores, os fatores que dificultaram as mulheres a aderirem as orientações do grupo educativo, em especial realizar o TMAP domiciliar, foram diversos e variaram ao longo das três entrevistas. A adesão às orientações também foi considerada na apresentação das barreiras.

$\mathrm{Na}$ primeira entrevista, as participantes que relataram estar aderindo às orientações conforme informado no grupo educativo consideraram barreiras o não lembrar de realizar o TMAP, a função da mulher como cuidadora, não entender como realizar os exercícios, a falta de tempo ou correria e o fato de realizar o TMAP não ser um hábito. Para as participantes que relataram estar aderindo às orientações, mas não como informado, não lembrar de realizar o TMAP, a função da mulher como cuidadora, não entender como realizar os exercícios, a falta de tempo ou correria também foram considerados barreiras, assim como não reconhecer que tem alguma disfunção do AP e a necessidade de sempre estar olhando na cartilha para lembrar do protocolo de treinamento. Uma participante relatou que não tem paciência para apoiar os pés em um banquinho durante a defecação. Já para as mulheres que não estavam seguindo nenhuma das orientações, não entender como realizar corretamente o TMAP foi a principal barreira mencionada, seguido pela falta de tempo ou correria.

Na tabela 15 é possível visualizar fragmentos ilustrativos das barreiras para aderir as orientações do grupo educativo indicados pelas participante que participaram da primeira entrevista. 
Tabela 15 - Apresentação das barreiras para a modificação de hábitos de vida identificados por 19 participantes, uma semana após o grupo educativo

\begin{tabular}{|c|c|c|}
\hline Facilitador & $\begin{array}{l}\text { Número de } \\
\text { menções }\end{array}$ & Exemplo \\
\hline \multirow[t]{2}{*}{$\begin{array}{l}\text { Não lembrar de } \\
\text { fazer o TMAP }\end{array}$} & 5 & $\begin{array}{r}\text { "A gente esquece da gente. Esquece um pouco da gente na correria." (P16, 42, IU, } \\
\text { C, DS })\end{array}$ \\
\hline & & $\begin{array}{r}\text { "Preguiça e a falta de lembrar, quando eu lembro ai eu faço, quando eu não lembro } \\
\text { eu não faço." (P18, } 48 \text { IU, C, DS) }\end{array}$ \\
\hline $\begin{array}{l}\text { Não entender } \\
\text { como faz o TMAP }\end{array}$ & 4 & $\begin{array}{r}\text { "É. Eu sempre, tipo assim, como “'saudar o dia”, mas puxando uma respiração, } \\
\text { segurando, sabe? Isso eu tenho mania de fazer" (P4, 63, IU) } \\
\text { "Porque eu não sei se estou fazendo certo, aí eu começo, aí eu falo "ah não acho } \\
\text { que está errado", se eu fizer errado não vai adiantar..." (P14, 54, IU, DS) }\end{array}$ \\
\hline $\begin{array}{l}\text { Não reconhecer } \\
\text { que tem } \\
\text { disfunções do AP }\end{array}$ & 3 & $\begin{array}{r}\text { "Como você não precisa muito você não lembra de fazer. Então, assim, mas é } \\
\text { válido, eu achei interessante. Mas se eu te falar que eu lembro de fazer é mentira, } \\
\text { porque eu não lembro." (P1, 44, IU, DS) }\end{array}$ \\
\hline $\begin{array}{l}\text { A falta de tempo } \\
\text { ou correria }\end{array}$ & 3 & “Oh, pra eu falar a verdade eu não tenho muito tempo viu” (P6, 70, IU, C) \\
\hline $\begin{array}{l}\text { Função da mulher } \\
\text { como cuidadora }\end{array}$ & 2 & $\begin{array}{r}\text { "Porque eu tenho que sair muito né.. quando eu não tenho que ir no médico, é o } \\
\text { meu marido e tem sempre minha netinha que eu tenho que cuidar... aí o tempo é } \\
\text { curto e faz do jeito que dá..." (P11,67, IU) }\end{array}$ \\
\hline Falta de paciência & 1 & $\begin{array}{l}\text { "Não, eu não coloquei ainda não [banquinho no banheiro]. Falei que achei bacana } \\
\text { mas ainda... nem vou colocar, não tenho paciência para isso não!" (P6, 70, IU, C) }\end{array}$ \\
\hline Não ser um hábito & 1 & $\begin{array}{r}\text { "Como não é um hábito da sua rotina de vida as vezes você esquece porque você } \\
\text { não marca um horario." }(\mathrm{P} 8,39)\end{array}$ \\
\hline Cartilha & 1 & $\begin{array}{l}\text { "(...) aí por exemplo igual, eu tenho que lê lá [na cartilha] para lembrar como faz, } \\
\text { porque se você falar para mim que está aqui na minha cabeça..." (P1, } 44, \mathrm{IU}, \mathrm{DS})\end{array}$ \\
\hline
\end{tabular}

$\mathrm{P}=$ participante; $\mathrm{IU}=$ incontinência urinária; $\mathrm{IA}=$ incontinência anal; $\mathrm{C}=$ constipação; $\mathrm{DS}=$ disfunção sexual; $\mathrm{POP}=$ prolapso dos órgãos pélvicos; $\mathrm{TMAP}=$ treinamento dos músculos do assoalho pélvico; $\mathrm{AP}=$ assoalho pélvico

$\mathrm{Na}$ segunda entrevista, as participantes que relataram estar aderindo às orientações conforme informado no grupo educativo consideraram barreiras a função da mulher como cuidadora, carga horária de trabalho formal e informal e o fato de realizar o TMAP não ser um hábito. Para as participantes que relataram estar aderindo às orientações, mas não como informado, a função da mulher como cuidadora, carga horária de trabalho formal e informal e o fato de realizar o TMAP não ser um hábito também foram considerados barreiras, assim como não lembrar de fazer o TMAP ou não lembrar do protocolo, não reconhecer que tem alguma disfunção do AP, a necessidade de precisar se concentrar para fazer os exercícios, uma baixa percepção de contração, não entender a importância do TMAP e associar a AVDs pouco usuais. Já para a participante que não estava seguindo nenhuma das orientações, não 
lembrar do protocolo de exercício, função da mulher como cuidadora, necessidade de sempre olhar na cartilha para fazer o TMAP e não reconhecer que tem alguma disfunção do AP foram as barreiras

Na tabela 16 é possível visualizar fragmentos ilustrativos das barreiras para aderir as orientações do grupo educativo indicados pelas participantes que participaram da segunda entrevista.

Tabela 16 - Apresentação das barreiras para a modificação de hábitos de vida identificados por 14 participantes, três meses após o grupo educativo

\begin{tabular}{|c|c|c|}
\hline Facilitador & $\begin{array}{l}\text { Número de } \\
\text { menções }\end{array}$ & Exemplo \\
\hline $\begin{array}{l}\text { Função da mulher } \\
\text { como cuidadora }\end{array}$ & 4 & $\begin{array}{r}\text { "É, esquece, ai menina é muita coisa. A gente que é dona de casa, mãe e eu cuido do } \\
\text { meu pai também." (P1, 44, IU, DS) } \\
\text { "Porque eu tô com três netos morando comigo definitivo." (P11, 67, IU) }\end{array}$ \\
\hline \multirow{2}{*}{$\begin{array}{l}\text { Carga horária de } \\
\text { trabalho/ falta de } \\
\text { tempo }\end{array}$} & 4 & $\begin{array}{l}\text { "Acho que falta de tempo porque eu sou sozinha pra fazer meu serviço da casa, tem } \\
\text { marido pra cuidar, trabalho fora, sou vendedora então não acho muito tempo não. Eu } \\
\text { acho pra esse ai, que eu já to deitada" (P6, 70, IU, C) }\end{array}$ \\
\hline & & “Tem dia que é uma correria e acaba não dá tempo." (P15, 54, IU, IA) \\
\hline \multirow{2}{*}{$\begin{array}{l}\text { Não lembrar de } \\
\text { fazer ou como } \\
\text { fazer o TMAP }\end{array}$} & 3 & $\begin{array}{r}\text { "Guardar aquela frequência assim... conta } 6 \text {, entendeu? Descansa tantos, eu nunca } \\
\text { lembro, se eu não ler como que é, entendeu?" (P1, 44, IU, DS) }\end{array}$ \\
\hline & & $\begin{array}{r}\text { "E tá certo que não lembro direto de fazer mas quando lembro eu faço, porque eu } \\
\text { acho que não tenho." (P17, 67, C, DS) }\end{array}$ \\
\hline $\begin{array}{l}\text { Não reconhecer } \\
\text { que tem } \\
\text { disfunções do AP }\end{array}$ & 2 & $\begin{array}{r}\text { "É que é o que eu falo quando a coisa ainda não tá acontecendo você não tem, você } \\
\text { fica meio assim relaxada." (P1, 44, IU, DS) }\end{array}$ \\
\hline $\begin{array}{l}\text { Necessidade de } \\
\text { concentração }\end{array}$ & 2 & $\begin{array}{r}\text { "Ás vezes eu não consigo me concentrar pra tá fazendo o exercício assim bem } \\
\text { feitinho" (P14, 59, IU, DS) }\end{array}$ \\
\hline $\begin{array}{l}\text { Não entender a } \\
\text { importância do } \\
\text { TMAP }\end{array}$ & 2 & $\begin{array}{l}\text { "Quando você faz um tratamento. Agora você não vai fazer o tratamento, ninguém } \\
\text { vai te cobrar, ninguém vai te examinar então fica meio que..." (P14, 59, IU, DS) }\end{array}$ \\
\hline Não ser um hábito & 2 & "Olha, eu acho que isso falta um pouquinho de criar o hábito." $(\mathrm{P} 8,39)$ \\
\hline Cartilha & 1 & $\begin{array}{r}\text { "Porque assim, não grava, eu tinha que ficar lendo e a minha filha tirou a apostila de } \\
\text { perto de mim." (P1, 44, IU, DS) }\end{array}$ \\
\hline $\begin{array}{l}\text { Baixa percepção } \\
\text { de contração }\end{array}$ & 1 & $\begin{array}{l}\text { "Ás vezes eu não consigo segurar quando vejo já soltou e aí eu fico até desanimada." } \\
\text { (P14, 59, IU, DS) }\end{array}$ \\
\hline Associar a AVDs & 1 & $\begin{array}{l}\text { "Eu já conciliei esse hábito de lembrar, então as vezes eu acabo fazendo mas vamos } \\
\text { supor, se eu fico } 10 \text { dias sem ver filme, eu fico } 10 \text { dias sem fazer." (P8, 39) }\end{array}$ \\
\hline
\end{tabular}

AVDs = atividades de vida diária; $\mathrm{P}=$ participantes; $\mathrm{IU}=$ incontinência urinária; $\mathrm{IA}=$ incontinência anal; $\mathrm{C}=$ constipação; $\mathrm{DS}=$ disfunção sexual; $\mathrm{POP}=$ prolapso dos órgãos pélvicos; $\mathrm{TMAP}=$ treinamento dos músculos do assoalho pélvico; $\mathrm{AP}=$ assoalho pélvico 
$\mathrm{Na}$ terceira entrevista, as participantes que relataram estar aderindo às orientações conforme informado no grupo educativo consideraram barreiras a carga horária de trabalho formal e informal, não lembrar de fazer o TMAP e não reconhecer que tem/ não ter alguma disfunção do AP. Uma participante relatou que não tem paciência para apoiar os pés no banquinho durante a defecação. Para as participantes que relataram estar aderindo às orientações, mas não como informado, a função da mulher como cuidadora, carga horária de trabalho formal e informal, não lembrar de fazer o TMAP e não reconhecer que tem/ não ter alguma disfunção do AP também foram considerados barreiras, assim como associar a AVDs. Já para as participantes que não estavam seguindo nenhuma das orientações, não lembrar de fazer o TMAP, a carga horária de trabalho formal e informal, a função da mulher como cuidadora foram as barreiras elencadas. Uma participante considerou ter outros problemas de saúde como um fator que a impede de lembrar de realizar o TMAP.

Na tabela 17 é possível visualizar fragmentos ilustrativos das barreiras para aderir as orientações do grupo educativo indicados pelas participantes que participaram da terceira entrevista.

Tabela 17 - Apresentação das barreiras para a modificação de hábitos de vida identificados por nove participantes, em um período de cinco a 16 meses após o grupo educativo

\begin{tabular}{|c|c|c|}
\hline Facilitador & $\begin{array}{l}\text { Número de } \\
\text { menções }\end{array}$ & Exemplo \\
\hline $\begin{array}{l}\text { Carga horária de } \\
\text { trabalho/ correria }\end{array}$ & 5 & $\begin{array}{r}\text { "O meu é a correria do dia a dia, tenho um monte de coisa para fazer. Mas é muito } \\
\text { difícil lembrar." (P1, 44, IU, DS) }\end{array}$ \\
\hline $\begin{array}{l}\text { Função da mulher } \\
\text { como cuidadora }\end{array}$ & 4 & $\begin{array}{r}\text { “Ah, não meu caso assim: eu tive um choque bem grande com um problema que eu tive } \\
\text { em casa lá com minha filha, que eu precisei viajar com ela, então assim, eu esqueci de } \\
\text { mim total." (P3, 40, IU, POP) } \\
\text { "Então, era bom se desse para fazer tudo, se a gente tivesse um tempo para tudo né mas } \\
\text { a vida da gente né, infelizmente... somos vó, eu olho o neto, levo para escola, faço um } \\
\text { monte de coisa né...” (P7, 65, IU, C, POP) }\end{array}$ \\
\hline $\begin{array}{l}\text { Não lembrar de } \\
\text { fazer o TMAP }\end{array}$ & 4 & $\begin{array}{r}\text { "Então. Ai tipo, quando você não tá condicionando sua mente, parece que não...é igual } \\
\text { uma academia mesmo, né?" (P3, 40, IU, POP) }\end{array}$ \\
\hline $\begin{array}{l}\text { Não reconhecer que } \\
\text { tem ou não ter } \\
\text { disfunções do AP }\end{array}$ & 2 & "No meu caso, eu não tenho problema ainda, né?! A incontinência urinária.” $(P 8,39)$ \\
\hline Associar a AVDs & 1 & "E agora faz tempo que eu não pego pra assistir filme." (P8, 39) \\
\hline Não ter paciência & 1 & $\begin{array}{l}\text { "Não, não tenho paciência de pegar um banquinho e colocar... mas não tenho mesmo." } \\
\text { (P6, 70, IU, C) }\end{array}$ \\
\hline Outras questões de & 1 & "Só que eu, depois daquilo que já aconteceu comigo [encontrado nódulo na mama], eu \\
\hline
\end{tabular}


AVDs = atividades de vida diária; $\mathrm{P}=$ participante; $\mathrm{IU}=$ incontinência urinária; $\mathrm{IA}=$ incontinência anal; $\mathrm{C}=$ constipação; $\mathrm{DS}=$ disfunção sexual; $\mathrm{POP}=$ prolapso dos órgãos pélvicos; $\mathrm{TMAP}=$ treinamento dos músculos do assoalho pélvico

\subsubsection{Percepção de mudança nos sintomas de disfunções do assoalho pélvico}

Uma semana após o grupo educativo, cinco mulheres relataram algum tipo de melhora em seus sintomas de disfunção do AP como IU, constipação e dor.

"Falei para eles que a noite eu levantava para ir ao banheiro, uma ou duas vezes eu acordava e já tinha que ir. Agora eu acordo, sinto que tem um pouquinho lá, mas eu não levanto, consigo segurar aí passa a vontade, eu durmo e só vou hora que acordo de manhã." (P7, 65, IU, C, POP)

"É. Que eu sou ressecada e também eu sinto muito, eu sinto dor assim e as dores assim diminui depois que eu comecei a participar, e comecei a fazer os exercícios." (P18, 48 IU, C, DS)

"Foi muito bom porque eu faço todo dia de manhã a massagem, levanto e ponho o pé no banquinho, "puis" um banquinho lá no meu banheiro, começou a melhorar minhas fezes, maravilha sabe?" (P19, 69, IU, IA, C, DS)

$\mathrm{O}$ número de mulheres relatando melhora dos sintomas de disfunção do AP se modificou para sete três meses após o grupo educativo, das quais quatro já haviam relatado melhora durante a primeira entrevista.

"Mas tem me ajudado muito, você não sonha o quanto. Que antes sabe quando ria muito? Soltava urina, hoje melhorou muito, eu não sei quantos por cento, se é $20 \%$, se é 30, então eu já to vendo resultados bons.” (P5, 46, IU, DS)

"Molhava muito mesmo a minha calcinha, agora diminuiu bastante só que não eliminou total sabe?" (P19, 69, IU, IA, C, DS)

"Continua melhor, eu to conseguindo segurar, quando eu saio que eu preciso ficar até duas horas e meia ou até três horas sem ir ao banheiro eu consigo segurar. Mas quando tem necessidade de segurar, eu seguro. E a noite eu levantava duas, três vezes por noite, agora eu to levantando uma para ir ao banheiro." (P13, 66, IU, POP) 
Sete mulheres relataram melhora dos sintomas de disfunções de AP em um intervalo de tempo de cinco a 16 meses após a participação no grupo educativo. Destas, três também relataram a melhora nas duas entrevistas anteriores. Uma participante teve um fragmento selecionado também na primeira entrevista. Os relatos referem-se a queixas álgicas, sintomas de trato urinário inferior, constipação intestinal e desempenho sexual.

"É, segurar o xixi, eu tenho né, uma vez ou outra escapa, agora já é mais do que menos." (P4, 63, IU)

"Assim, depois também, outra coisa que mudou na minha vida foi o desempenho sexual que melhorou bastante, aí eu acho que foi totalmente por conta dos exercícios" (P3, 40, IU, POP)

"Porque eu tenho o intestino preso, então o banquinho, nossa, santo banquinho! salva a vida." (P17, 67, C, DS)

"Então eu fico, eu ponho o pé, como vocês explicaram no banquinho lá, e melhorou [sintomas de esvaziamento vesical incompleto]" (P19, 69, IU, IA, C, DS)

Cabe destacar que duas mulheres que interromperam o TMAP domiciliar notaram e relataram o retorno dos sintomas antes de iniciar o exercício. Os relatos de piora dos sintomas urinários podem ser observados abaixo.

"Depois eu tive que parar por problema pessoal também, e daí tô assim: totalmente sem fazer nada, e ai volto todos os problemas [de incontinência urinária] da estaca zero." (P3, 40, IU, POP)

“Eu deixei os exercícios e ai tá de novo prejudicando...” (P19, 69, IU, IA, C, DS)

\subsection{TEMA 4 - LIDANDO COM SINTOMAS DE DISFUNÇÕES DO ASSOALHO PÉLVICO}

Nesse tópico será descrita a relação das mulheres com o seu sintoma de disfunção do AP. Ele engloba a percepção de existência do mesmo, a aceitação dos sintomas, o impacto que ele gera no dia-a-dia e como ela percebe seu AP, em especial os MAP. 


\subsubsection{Os sintomas}

Apesar de não compor o quadro de tópicos a serem discutidos, algumas participantes sentiram necessidade de externar o convívio com sintomas de disfunções do assoalho pélvico como sintomas de trato urinário inferior, constipação e disfunção sexual. Oito participantes relataram sintomas como noctúria e diversos tipos de IU. Três mulheres trouxeram relatos de disfunção sexual e três sobre constipação.

"Eu bebo bastante água e faço xixi várias vezes. A noite mesmo levanto duas vezes na noite, levanto fazendo xixi, com a calcinha pingando. Incrível. Toda noite." (P2, 54, IU, C, DS)

"Nossa, é só tossir, meu Deus, tossiu, saiu, tossiu, saiu. Quando fico resfriada então, nem se fala. Ponho até frauda de tanto que sai. (...) quando fico com tosse, aquela tosse forte, sai de monte, monte mesmo." (P5, 46, IU, DS)

"Tô fazendo, tá molhado as vezes, assim, a calcinha, sabe? A calcinha molha tudo, to usando môdis, mas eu tenho certeza que a hora que eu passar isso já vai voltar tudo ao normal de novo." (P19, 69, IU, IA, C, DS)

"Eu por exemplo tenho muita dor, mas é... falta de lubrificação, musculatura, tudo envolve essa musculatura né?” (P19, 69, IU, IA, C, DS)

"O porquê de ter intestino preso, olha, no meu caso é, eu não sei, a vida inteira eu tive, talvez não sei se é por conta de alimentação porque eu lembro que desde mocinha mesmo, um problema sério assim de ficar muito tempo sem ir fazer, as vezes mais de duas semanas." (P17, 67, C, DS)

Cabe destacar que uma participante, além de trazer o relato de ter IU narrou o seu processo de aceitação do sintoma.

"Eu também era muito nova quando comecei com essa história... eu tinha 23 e aí eu convivi com isso achando que era normal né... Eu até me preocupei no início mas depois eu me acostumei com a disfunção... falei assim, ah, vou levando... É bem triste assim, uma pessoa chegar ao ponto de ficar tantos anos com o problema" (P3, 40, IU, POP) 


\subsubsection{Influência e impacto das disfunções do assoalho pélvico}

Esse item consta com a apresentação do impacto de ter e/ou conviver com alguém que tem queixas de sintomas de disfunções do AP. Ter disfunções do AP impactou de forma diferente em cada mulher, seis mulheres relataram que ter IU inflige fatores envolvendo sua visão de si em relação ou não ao mundo e de fatores psicossociais e uma relatou sobre conviver com a constipação.

"Eu me sinto fora de controle. Sem controle." (P3, 40, IU, POP)

"Eu me vejo diferente [dos outros], porque eu tô com esse problema, e a pessoa não tá, então eu sou diferente." (P18, 48, IU, C, DS)

"Então, assim, dependendo do lugar que eu vou que não tenha banheiro adequado pra mim eu já fico incomodada." (P1, 44, IU DS)

"Afeta. Quando você faz um pouquinho de xixi na calça e você tá andando, você já começa a ficar olhando pro lado para ver se tem alguém, dá impressão que você tá fedida né, incomoda sim, afeta sim.” (P7, 65, IU, C, POP)

“É... preocupação de banheiro, também, de ficar perdendo xixi, usar Modess, incomoda. Às vezes, cê quer pôr uma roupa pra sair, pra ir numa festa, cê fica com medo de aparecer, apesar de que se tem um Modess pequeno, bem pequeno. Mas... "será que vai aparecer, será que vou... sentar, vai molhar, vai aparecer alguma coisa?”... então, é, é desconfortável.” (P19, 69, IU, IA, C, DS)

"Aí eu, tipo, se eu quero ir num show eu fico pensando: "ai, eu tenho que usar absorvente, não posso pular, não posso dançar"... ou então eu tenho que ir várias vezes no banheiro pra não ficar... pra não acontecer, né. Aí já vou no banheiro antes de ter vontade. eu troco várias vezes de calcinha..." (P3, 40, IU, POP)

"É ruim né, porque às vezes você tá na rua, vai tossir e molha a calcinha, aí você fíca com aquela calcinha molhada, é ruim.” (P6, 70, IU, C)

"Me sinto empazinada sabe [sobre a constipação], achada, ah é horrível isso, me sinto... me dá mal estar." (P6, 70, IU, C)

Além dos relatos relativos ao impacto das disfunções do AP, três participantes trouxeram relatos sobre o convívio com familiares que tem sintomas urinários e como esse convívio as impactou. 
"Minha mãe está com demência grave e ela perde xixi demais. E eu to ficando doente, tô ficando pior que ela porque eu vejo o dia a dia da doença e isso está acabado comigo. E ela faz xixi a noite inteira. Ela levanta com um tanto assim de pano [gesto com as mãos mostrando muito] que ela coloca no meio da perna, molha e ela coloca alí no chão e vai trocando. Fica um mal cheiro. E eu vi na internet que é da demência, a pessoa não assimila. Ainda tá nesse ponto dela tá pondo o forro e ficar troncando, mas vai chegar um ponto que não sei o que vai ser.” (P2, 54, IU, C, DS)

“Achei, porque minha mãe tem o intestino tão... intestino não, urina, tão solta que ela tem que usar fralda direto porque ela não consegue mais controlar, ela solta direto sabe? Não consegue mais esperar para ir no banheiro. Já fez cirurgia de bexiga. já fez algumas coisas, mas não sei se é psicológico, não sei... mas não consegue. (...) Mas eu tenho minha preocupação, por que minha mãe tem, né?" (P4, 63, IU)

\subsubsection{Auto percepção do assoalho pélvico}

Oito mulheres narraram sobre a auto percepção corporal, especialmente o assoalho pélvico. Relaxado, sem força, fraco, molhado, não sente, caído, esquecido e agarrado foram termos usados para descrever a como as participantes percebem seu assoalho pélvico.

Eu percebo, é, sem, sem força, percebo bem assim... É eu percebo que assim, eu não tenho força na estrutura aqui do tronco. Percebo assim, que falta força. (P3, 40, IU, POP)

Eu posso falar que tá caído também (P19, 69, IU, IA, C, DS)

Mais relaxado! Eu sinto ele bem relaxado. Por era incômodo, de primeiro. (P18, 48,IU, C, DS)

Agora no meu caso, eu sinto ao contrário.. Eu sinto que ele é relaxado, mas que eu tenho que contrair $(\mathrm{P} 8,39)$

Você sente que tem alguma coisa importante que tá aqui agarrado em você... (P7, 65, IU, C, POP)

Eu acho que a gente deveria ter mais consciência corporal dessa região. A gente acaba não pensando nessa região. Porque a gente não exercita, a gente não pensa. Então a gente não sente. (P3, 40, IU, POP) 


\subsection{TEMA 5 - REPRESENTAÇÃO SOCIAL}

Nesse tema haverá apresentação dos estigmas presentes na perspectiva coletiva que reflete na visão individual sobre a comunicação e expressão de assuntos íntimos como as disfunções do AP e sexualidade.

\subsubsection{Comunicação e estigma}

A comunicação sobre as disfunções do AP foi um assunto que apareceu em vários momentos da primeira e da terceira entrevistas. A liberdade de fala dentro e fora do grupo educativo esteve relacionada a um discurso com certo estigma em relação a idade e gênero.

Apesar da maioria das participantes do grupo se sentirem confortáveis com as discussões que aconteceram no grupo educativo, cabe destacar que quatro participantes externaram certo constrangimento com a liberdade de discutir assuntos da intimidade que o ambiente proporciona. Duas participantes também relataram resistência para discutir sobre o assunto em ambientes externos.

"Eu achei que teve uma que extrapolou um pouco sabe, desnecessário, eu na minha opinião, que extrapolou falando muita coisa que nem da palestra... aquilo era particular dela, entendeu?" (P14, 54, IU, DS)

"Olha, eu vou falar francamente para você, o que eu não gostei foi daquela pessoa, (...), que eu achei que não era necessário ela falar o que ela falou...” (P6, 70, IU, C)

"Um pouco de timidez assim né. Então assim... Por exemplo, lá em casa meu marido nem sabe o que eu estou fazendo aqui agora. Então.... (...) As mulheres ficam tímidas para falar sobre." [Alteração no tom de voz para chateação, postura mais protetiva e modificação da expressão facial com aumento da lacrimação] (P3, 40, IU, POP)

Sete mulheres acreditam que as disfunções do AP é e deve ser um assunto discutido com todos, independentemente de ser ou não homem, enquanto duas mulheres preferem não discutir esse assunto homens. 
"Porque, pra mim, não... porque se ele tivesse entre a gente, é porque ele tem o mesmo problema que a gente e precisava estar ouvindo, pra aprender, porque poderia acontecer com ele também, mesmo o sexo dele sendo diferente." (P18, 48, IU, C, DS)

"Em casa esse assunto é tão falado, né? Por causa da minha nora, né? Então e um assunto bem normal ali, bem normal na nossa família por causa disso né? Dela trabalhar com isso." (P17, 67, C, DS)

"Eu acho que desenvolve melhor enquanto só tem mulheres. Eu tenho vergonha de falar com meu marido sobre isso" (P3, 40, IU, POP)

"Eu não tenho coragem não. Não é que eu não tenho coragem, deixa eu te explicar, eu tenho um marido que é muito difícil de conversar, ele não gosta muito de conversa." (P6, 70, IU, C)

Nos discursos das participantes pode-se notar a presença de um estigma sobre as disfunções do AP em relação à idade $(n=5)$, constrangimento social $(n=3)$, homens $(n=2)$ e onde procurar tratamento $(\mathrm{n}=2)$.

"Então a gente tem que prevenir para tudo né, olha aí o assoalho pélvico, vocês se previnem para quando ficar velha não ficar igual nós.” (P7, 65, IU, C, POP)

"E é mais comum do que a gente imagina né. Eu não tinha ideia... eu achei que era só coisa de velho mesmo..." (P3, 40, IU, POP)

"E tinha uma senhorinha perto de mim, cada exercício, aí ela ficava assim: "ai, cê escutou o barulho? Eu tô com uma osteoporose... tá estralando tudo!" aí eu falei: mudou o nome!" [risos] (P19, 69, IU, IA, C, DS)

"Tá um homem na frente da gente, o médico.. a médica tudo bem, por exemplo, uma mulher tudo bem.. mas um homem, constrange a gente, né?!” (P18, 48,IU, C, DS)

"Sexual não, se a gente tem um problema, qualquer coisa a gente vai no ginecologista, explica, eu sei que vai ter um tratamento, vai orientar você, né?! Mas agora sobre isso ai né, perda de urina é mais difícil.” (P5, 46, IU, DS)

Em relação a como as participantes se referem ao assoalho pélvico ou região genital, as palavras usadas foram variadas e a escolha da palavra não parece ter relação com a idade do interlocutor ou do ouvinte. As palavras mais usadas para descrever essa região foram perereca $(n=5)$, vagina $(n=2)$, pepeca $(n=2)$, dirce $(n=2)$ e assoalho pélvico $(n=2)$. Florzinha, buceta, xereca e minha região pélvica foram citados uma vez cada. Duas participantes 
mencionaram que nunca se referiram ou que evita falar sobre essa região, sendo o uso da palavra "vagina" criticada. Uma participante relatou que os termos usados para se referir a região genital feminina também podem ser usados como insultos.

"A parte íntima da gente a gente fala "perereca", né?! Mas não é perereca. A perereca, eu até falo pra minha netinha, que é a mulher do sapo, aquela que fica na beira do rio, junto do sapo. Essa parte que a gente tem aqui é a vagina. Não é perereca!” (P18, 48, IU, C, DS)

“Dirce, é. As minhas amigas da academia fala dirce." (P1, 44, IU DS)

“É, hoje se eu tiver que explicar eu falo o assolho pélvico também” (P8, 39)

"Mas eu nunca falo da minha [região genital], naturalmente." (P17, 67, C, DS)

"Mas, por exemplo, às vezes alguém fala assim: "BUCETA!", como fosse um palavrão, como fosse um xingamento. Já percebeu?” (P3, 40, IU, POP)

\subsection{2. $\quad$ Sexualidade}

Nesse tópico haverá a apresentação de aspectos relacionados à expressão da sexualidade pelas participantes e da sexualidade de terceiros segundo as mesmas. Ao longo das três entrevistas, cinco mulheres levantaram questões que refletem a representação social da relação sexual e/ou sexualidade de sua própria pessoa ou de terceiros. As consequências de uma criação conservadora estiveram presentes no discurso de duas mulheres, assim como a exaltação da postura compreensiva do homem em relação ao relato de disfunção sexual feminina. Emergiu também a visão do sexo como uma obrigação quase servil da mulher no casamento. Uma postura conservadora também pode ser observada em quatro relatos sobre a expressão de sua sexualidade e, principalmente da sexualidade de terceiros. Houve um relato que expressa a naturalização do desejo sexual à masculinidade, comparando com homens mulheres que tem um intenso desejo sexual.

"Eu acho que foi muito trauma, que eu tive, desde... minha mãe sempre, é... assim, sei lá. Ela, ela tinha como... o sexo como coisa assim... muito medo, ela punha muito medo na gente. Então podia abraçar, beijar mas daqui para cá [gestos indicando da cintura para baixo]... Então, quando casei eu passei mal... casei virgem. (...) Então, 
pior coisa da minha vida. Foi a pior coisa da minha vida. Então, lua de mel pra mim não existiu, foi lua de ferro, eu chorava... eu chorava. Parecia que eu tinha engolido um porco-espinho pela garganta..." (P19, 69, IU, IA, C, DS)

"Tinha uma mulher que já fazia seis meses que era casada e ainda era virgem. O marido tava quase para largar dela. Ela não conseguia, ela tinha dor. Aí a médica começou a fazer uns tratamento com ela e foi ajudando. Você acha, que absurdo, o marido lá 6 meses e ainda não tinha conseguido! Esse foi bom em, ele esperou esse tempo...” (P2, 54, IU, C, DS)

"É as coisas estão mais liberais. O sexo ta muito... Tem que ser tratado com normalidade, né? Claro. Mas tem coisas que... Eu acho que tem algumas coisas têm que pôr um pouco de limite. É, porque num tá tendo. Num tá tendo limite." (P17, 67, C, DS)

"Mas tem mulher que é igual homem, tem um fogo que meu Deus do céu... tiro o chapéu para elas!” (P2, 54, IU, C, DS)

Apenas três participantes sentiram confiança para relatar durante as entrevistas aspectos da sua sexualidade. Devido o teor central, um dos relatos já foram apresentados como representação do impacto da criação conservadora na expressão da sexualidade. Os outros dois fragmentos podem ser observados abaixo.

"Eu e meu marido quando fico um tempo sem, eu fico doidinha. Chego a sonhar! A minha mãe que era muito fogueteira e a minha irmã mais velha é. Eu já sou mais assim... só que agora, eu acho que é porque eu parei de tomar o anticoncepcional. Tomei por 17 anos. Diz que o anticoncepcional inibe...” (P1, 44, IU DS)

"É, falou um pouco. Mas como eu falei que sou viúva há muito tempo, não falou muito. Mas quando eu tinha meu parceiro sempre foi tudo normal..." (P4, 63, IU)

\subsection{TEMA 6 - BUSCA E ADESÃO AO TRATAMENTO PARA DISFUNÇÕES DO ASSOALHO PÉLVICO}

Esse tema emergiu de falas onde identificam-se fatores que poderiam influenciar ou influenciaram na busca e adesão das mulheres ao tratamento para disfunções do AP como o modo que é atendida, o atendimento médico e algumas barreiras e facilitadores na busca pelo atendimento fisioterapêutico. 
Foram considerados aspectos essenciais da relação entre profissional da saúde e paciente o diálogo podendo ser presencial ou não $(n=3)$, acolhimento $(n=2)$, segurança $(n=1)$, simplicidade $(n=1)$, carinho $(n=1)$, simpatia $(n=1)$, paciência $(n=1)$ e educação $(n=1)$. Foram considerados aspectos negativos da relação profissional da saúde e paciente a arrogância $(n=1)$, grosseria $(n=2)$ e a falta de educação $(n=1)$. Duas participantes relataram que é importante haver educação também dos pacientes para com o profissional de saúde.

"E a gente vai se aproximar de quem a gente teve mais acolhimento e mais carinho.." $(\mathrm{P} 8,39)$

"O diálogo... eu não tenho problema nenhum com ninguém, desde que num seja um grosso comigo, que aí eu num volto mais, mas se são atenciosos, aí flui." (P1, 44, IU DS)

"Tipo, nossa, esqueci de perguntar aquilo... várias vezes tive vontade [de mandar whatsapp]!!” (P3, 40, IU, POP)

“Tem pessoa que é mal criado com os profissionais, e como tem porque eu já vi muito, falta de educação das pessoas.” (P4, 63, IU)

Relatos sobre a importância de um atendimento adequado apareceram no discurso de seis participantes. Para duas participantes, o atendimento adequado foi essencial para elas buscarem tratamento para IU, enquanto duas voluntárias queixaram-se de como foi orientada a tratar do seu sintoma. Uma participante trouxe relato de insatisfação sobre a busca por um diagnóstico para seu sintoma urinário e uma outra participante relatou que seria importante que o médico questionasse em todo atendimento sobre os sintomas de disfunções do AP.

“(...) porque até com os médicos eu ficava meio assim de falar sabe... no inicio, quando eu percebi. Aí quando me acostumei falei "ah, deixa quieto". Aí como ela chegou para mim e falou "ah, ta acontecendo isso, então vamos..." então foi legal, eu fiquei tranquila para me abrir..." (P3, 40, IU, POP)

“A gente que trata no posto de saúde muitas vezes não pega médico bom, ele está ali para se aposentar mesmo, eu vejo assim meu médico entendeu? então eu vou lá eu reclamei disso [IU] para ele e ele falou "emagrece". Então eu já sai assim, se eu não emagrecer não tem solução.” (P14, 54, IU, DS) 
"Eu fui fazer, eu fiz aquela parte do exame lá pra ver o.. como fala? A..., a textura, não. A... como fala? [se referindo possivelmente a urodinâmica] Não deu nada. Disse que eu não tinha nada, só que ta todo dia a calcinha tá molhada, aí eu tive, tem que usar modis" (P19, 69, IU IA, C, DS)

"Se você vai no médico e ele passa pra você que existe esse tipo de problema, você já se abriria com ele, só que muitas vezes ele num vai te perguntar disso. Eles só pergunta se você faz xixi, se você faz cocô, só isso. Mas num chega a perguntar se você tem incontinência..." (P1, 44, IU DS)

Em relação as barreiras e facilitadores para o tratamento fisioterapêutico para as disfunções do AP, foram elencados como barreira o atendimento público e o percurso para chegar ao atendimento especializado $(n=5)$, atendimento médico inadequado $(n=4)$, falta de informação $(n=4)$, vergonha $(n=2)$, condição financeira $(n=2)$, correria $(n=2)$, a necessidade de passar pela avaliação fisioterapêutica $(n=1)$ e a falta de valorização pessoal $(n=1)$. Foram considerados facilitadores as informações discutidas no grupo educativo $(n=5)$, mudar sistema de referência e contra referência $(n=1)$ e ter condições para buscar o atendimento particular $(\mathrm{n}=1)$.

"No nosso caso, no SUS, cê vai pra fila, é um ano." (P1, 44, IU DS)

"Igual agora com toda essa matéria que a gente teve, a gente está pronta para prosseguir e fazer tratamento, fazer o que for preciso né. Só que aí vai depender do encaminhamento lá do posto central, do posto de saúde que a gente vai..." (P15, 54, IU, IA)

"Ai eu fui nas clínicas comentei novamente com a médica e ela mandou eu tomar um remédio acho que Retinix, alguma coisa assim e eu tomei, comecei a tomar mas me deu tanta... foi tudo ao contrário, começou a me doer muito a cabeça, dar mal estar e eu falei não, não vou tomar esse remédio. Parei. Quando eu voltei a médica falou: "a senhora parou?" Eu falei: "Dra. eu parei porque eu não tava conseguindo tomar o remédio. Eu tomava o remédio, eu tomei quase uma caixa, ficou pouquíssimos comprimidos mas não me adaptei de jeito nenhum e eu prefiro fazer outro tipo de tratamento se houver outro tratamento eu vou fazer". Bom, ai ela falou: "bom então vamos ver...”." (P19, 69, IU, IA, C, DS)

"Falta de informação. eu acho que e a informação por parte do paciente que dificulta buscar ajuda..." (P3, 40, IU, POP) 
"Ah sim, com certeza, eu acho que [o grupo educativo] aumenta o seu desejo de fazer a avaliação do toque para você ter certeza que grau que você está nessa musculatura, se precisa mesmo fazer com mais constância os exercícios né, achei que foi muito bom essa pesquisa [lê-se grupo] para a gente chegar na avaliação" (P15, 54, IU, IA)

"E um encaminhamento daqui, a gente já está aqui, vai voltar para depois vir para cá outra vez..." (P14, 54, IU, DS)

“É mais fácil pra conseguir no particular." (P1, 44, IU DS) 


\section{DISCUSSÃO}

Essa pesquisa teve como objeto de estudo o programa de educação em saúde voltado ao AP feminino que é conduzido no CSE da FMRP-USP e destinado a mulheres da comunidade com o objetivo de informa-las sobre anatomia, função, disfunções do AP e e opções de tratamento com ênfase no tratamento conservador por meio de mudanças nos hábitos de vida e treinamento dos músculos do assoalho pélvico. A partir desse objeto de estudo buscou-se compreender a perspectiva de mulheres sobre sua participação no mesmo, descrever o impacto deste na vida de suas participantes, quer seja pelo desenvolvimento de novos conhecimentos ou inserção de orientações oferecidas durante o grupo no cotidiano, além de descrever as barreiras e facilitadores para aderir à essas orientações. Também foi objetivo do estudo contextualizar a atividade educativa uma vez que a mesma é ministrada por diferentes grupos de estagiários e apresentam especificidades em cada oferecimento. Cabe destacar que, como não foi realizada uma análise com temas pré-definidos, alguns resultados obtidos extrapolam os objetivos da pesquisa. Esse ocorrido pode ser visto como uma forma de agregar valor aos resultados, uma vez que as respostas aos objetivos da pesquisa foram, ao nosso ver, complementados.

Devido a densidade de informações resultantes das entrevistas, a presente discussão irá focar nos aspectos relacionados aos objetivos do estudo.

\subsection{CONTEXTUALIZAÇÃO DA ATIVIDADE DE EDUCAÇÃO EM SAÚDE}

Com a descrição detalhada da atividade de educação em saúde presente nos resultados, podemos observar que o grupo aborda os principais aspectos da fisiopatologia das disfunções do AP e opções de tratamento. Durante o grupo, há orientações sobre o TMAP domiciliar, massagem abdominal, elevação dos pés durante a evacuação, adequação da ingestão hídrica, frequência miccional e consumo de alimentos irritativos do trato urinário inferior. 
Apesar de escasso, há outros formatos de educação em saúde voltado ao AP feminino destinados a mulheres da comunidade descritos na literatura internacional (DIOKNO et al., 2018; ZHANG et al., 2016; BERZUK; SHAY, 2015). A atividade educativa proposta no estudo de Diokno et al. (2018) teve duração de um encontro de duas horas. Ela contou com apresentação de slides para discutir assuntos como anatomia do trato urinário inferior; função vesical e dos MAP; anatomia e fisiologia da continência; tipos, causas e impacto da IU; TMAP; treinamento vesical e; modificação em hábitos de vida. Um material sistematizando o que foi discutido e uma gravação para realização o TMAP domiciliar foram entregues no final da atividade (DIOKNO et al., 2018). Na educação em saúde realizada no estudo de Zhang et al. (2016), houveram palestras sobre saúde, atendimento médico e entrega de cartilha. As palestras discutiam assuntos como manifestação clínica, diagnóstico, riscos e tratamento conservador da incontinência urinária de esforço (i.e. como realizar o TMAP) com duração de, pelo menos dois encontros de uma hora. A cartilha entregue apresentava um resumo do conteúdo discutido (Zhang et al., 2016). Já a atividade educativa utilizada no estudo conduzido por Berzuk \& Shay (2015) teve duração de 60 minutos com apresentação sobre a saúde do AP, função dos MAP, instrução verbal de um programa domiciliar de fortalecimento dos MAP e estratégias comportamentais. Essa atividade foi realizada com ou sem um segundo momento de prática após dois meses do primeiro (BERZUK; SHAY, 2015).

Apesar de eficazes, os trabalhos descritos anteriormente não explicam as bases utilizadas para estruturação das atividades ao contrário do estudo de Chiarelli \& Cockburn (1999). Tal estudo estruturou uma atividade educativa objetivando a promoção da continência considerando os dados emergentes de grupos focais e o Health Belief Model. Segundo os autores, o grupo deveria abordar sobre o conhecimento geral do sintoma; a auto eficácia com visualização do períneo, palpação externa do AP durante a contração dos MAP e TMAP como parte das AVDs; habilidades práticas como a auto avaliação da contração e auto manejo da progressão do TMAP; a percepção de susceptibilidade com dados de prevalência e fatores de risco; a percepção da seriedade com detalhes sobre a progressão da IU; os benefícios esperados com o TMAP; as possíveis barreiras; e estratégias de ação 
individuais. Somente assim as pessoas passariam a realizar o TMAP domiciliar e adotariam hábitos miccionais saudáveis (CHIARELLI; COCKBURN, 1999).

Outras áreas de atenção à saúde que usam a mudança em hábitos de vida como parte essencial do tratamento têm discutido formas de melhorar a adesão às orientações com atividades educativas voltadas a esse objetivo. A educação de pacientes com diabetes tipo 2 tem buscado mudar o foco de suas atividades ao usar abordagens de "auto eficácia e auto manejo" para estimular o paciente a se responsabilizar por sua própria saúde ao invés de "construção da capacidade de aderir ao tratamento" em pacientes incapazes de aderir ao tratamento (TOL et al., 2015). Essa abordagem alternativa foca no envolvimento do paciente em seu autocuidado ao invés de somente informar sobre a doença e opções de tratamento (TOL et al., 2015).

\subsection{PERCEPÇÃO SOBRE A ATIVIDADE EDUCATIVA}

De modo geral, as participantes consideraram o grupo educativo adequado em relação ao formato de quatro encontros de uma hora, como ele foi conduzido e aos assuntos abordados. O uso dos cartazes foi elogiado pela maioria das participantes, as quais consideraram o ato de participar do grupo educativo importante pois abordou assuntos desconhecidos, mas relacionados aos sintomas que convivem. Algumas sugestões para melhorar o grupo foram oferecidas, entretanto não houve uma similaridade quanto as mesmas. Sendo assim, podemos julgar o formato pré-estabelecido do grupo educativo adequado sob a perspectiva das participantes.

O objetivo do grupo educativo é informativo sendo assim, apesar de não ser objetivo do presente estudo avaliar o conhecimento desenvolvido com o grupo educativo, os relatos de conhecimento emergentes das entrevistas podem ser considerados reflexos da adequação do conteúdo do mesmo para atingir seu objetivo. Tal pensamento é intensificado quando analisamos os tópicos mais abordados nos grupos (tabela 10) e fazemos uma intersecção com os relatos de conhecimento construído. Desta forma podemos perceber uma baixa densidade e até ausência de fragmentos textuais ilustrativos do conhecimento relativo a 
alguns dos tópicos como a diferença entre musculatura lisa e estriada, tópico discutido em sete dos oito grupos.

O ensaio clínico randomizado e controlado (ECRC) conduzido por Andrade et al. (2018) teve como amostra mulheres da comunidade incluídas com ou sem sintomas de disfunções do AP e a intervenção foi o grupo educativo ao qual essa pesquisa se refere. $\mathrm{O}$ estudo demonstrou que a atividade é capaz de gerar melhora do conhecimento das mulheres sobre as disfunções do AP. Os estudos conduzidos por Berzuk \& Shay (2015) e Zhang et al. (2016) também demostraram que as atividades educativas propostas geraram aumento do conhecimento de suas participantes sobre o conteúdo proposto. Cabe destacar que, apesar de eficazes para melhorar o conhecimento das mulheres sobre função dos MAP, disfunções do AP e tratamento conservador não farmacológico, os grupos mencionados não relataram terem sido embasados em princípios de promoção à saúde ou teorias modificadoras da adesão, podendo ser considerados grupos com objetivo informativo.

Em relação à motivação para participar do grupo, a maioria das mulheres relataram que participaram devido ao desejo de obter mais conhecimentos sobre os sintomas de disfunções do AP. O desejo externado por um número expressivo de mulheres poderia ser um reflexo direto da alta prevalência da principal disfunção do AP, a IU (TAMANINI et al., 2017; WU et al., 2014) associado ao baixo conhecimento das mesmas sobre esse assunto (CHIARELLI; COCKBURN, 1999; DE FREITAS et al., 2018; NEELS et al., 2016a, 2016b).

A motivação das mulheres em participar do grupo educativo somado ao baixo número de pessoas com algum conhecimento sobre o AP (DE FREITAS et al., 2018; DE ANDRADE et al, 2018) e a baixa qualidade do conhecimento existente (DE FREITAS et al., 2018) demonstram a necessidade de oferecer mais atividades de educação em saúde para informar a população feminina atendida no contexto de saúde pública brasileiro. Oferecer mais informações adequadas sobre as disfunções do AP poderá fazer com que o número de mulheres procurando tratamento para seu sintoma aumente (MARGALITH; GILLON; GORDON, 2004) e melhore a adesão ao tratamento conservador não-farmacológico, especificamente o TMAP (HAY-SMITH et al., 2015). 


\subsection{MODIFICAÇÃO EM HÁBITOS DE VIDA}

Apesar de não ser objetivo do grupo gerar modificações em hábitos de vida, as mulheres relatam modificar algum hábito após o mesmo. Podemos observar nos relatos que as mulheres apresentam uma alta adesão ao TMAP uma semana após o grupo, entretanto ocorre uma variação da proporção de mulheres que relataram estar realizando o TMAP ao longo dos três tempos de entrevistas. A redução da adesão ao TMAP ao longo do tempo também foi relatada em outros estudos de diferentes metodologias (ALEWIJNSE et al., 2003b; HYLAND; HAY-SMITH; TREHARNE, 2013; OUCHI et al., 2018).

Apesar de não ser o intuito da presente metodologia avaliar a eficácia do grupo educativo para gerar modificação em hábitos de vida, ao observarmos o perfil das mulheres que se interessam em participar do grupo educativo podemos observar que a maioria já apresenta sintomas de disfunções do AP. Ao considerarmos essa possível demanda reprimida de pacientes e a redução dos relatos de adesão às orientações ao longo do tempo, podemos inferir uma necessidade de readequar o objetivo e formato do grupo para manutenção das modificações em hábitos de vida. A adesão ao TMAP não-supervisionado parece relacionada à identificação e manejo das barreiras e facilitadores de cada paciente (HAY-SMITH et al., 2015) e boa adesão inicialmente ao tratamento (ALEWIJNSE et al., 2003b).

É descrito na literatura algumas teorias que podem ser usadas em educação em saúde para modificar o comportamento de adesão ao TMAP, sendo as mais frequentes o Social Cognitive Theory e Health Belief Model (DUMOULIN et al., 2015). Apesar de existir similaridades entre as teorias algumas diferenças devem ser pontuadas e consideradas. $\mathrm{O}$ Social Cognitive Theory envolve conceitos como expectativas e incentivos; o primeiro está relacionado a crença do indivíduo de que eventos estão conectados, de que atitudes individuais geram os resultados esperados (expectativa de resultado) e na capacidade de realizar o comportamento necessário para gerar os resultados esperados (auto eficácia); já o segundo refere-se a existência de um valor agregado ao resultado esperado (ROSENSTOCK et al., 1988). Enquanto o Health Belief Model depende da existência simultânea de motivação, crença na vulnerabilidade (ameaça percebida) e na possibilidade de vencer a ameaça percebida seguindo as orientações propostas à um custo aceitável. Nesse modelo, o 
conceito de custo refere-se, não somente ao valor financeiro, mas também ao impacto de vencer as barreiras (ROSENSTOCK et al., 1988).

Considerando o valor complementar das duas teorias levanta-se as seguintes questões: (1) As mulheres acreditam que o TMAP causa melhora dos sintomas de disfunções do AP? (2) A melhora ou prevenção dos sintomas de disfunções do AP é importante para as mulheres? (3) As mulheres percebem a ameaça (i.e. disfunções do AP)? (4) As mulheres acreditam que são capazes de realizar o TMAP domiciliar? (5) As mulheres estão motivadas para realizar o TMAP domiciliar? (6) As mulheres acreditam que ao realizar o TMAP domiciliar haverá melhora ou prevenção dos sintomas de disfunções do AP? (7) O resultado esperado com o TMAP apresenta um custo aceitável pelas mulheres (barreiras)? Se as perguntas levantadas fossem respondidas utilizando os resultados do presente estudo nem todas apresentariam uma resposta afirmativa.

\subsection{FATORES MODIFICADORES DA ADESÃO}

Assim como o relato de adesão, os fatores que modificam a adesão das mulheres às orientações realizadas durante o grupo educativo também variaram no decorrer das três entrevistas em número e em proporção de menções. Os principais facilitadores a curto prazo foram as informações discutidas no grupo educativo, o desejo das mulheres em melhorar e a cartilha entregue ao final do grupo educativo. Já a médio prazo foi associar o TMAP à AVDs, as informações do grupo educativo e o querer ou sentir que melhorou os sintomas de disfunções do AP. A longo prazo foi associar o TMAP à AVDs, uso de lembretes e as informações do grupo educativo. Já as principais barreiras a curto prazo foi não lembrar de realizar o TMAP, não entender como realizar o exercício e não reconhecer que tem disfunções do AP. A médio e longo prazo foi a função da mulher como cuidadora, a carga horária de trabalho culminado em falta de tempo e não lembrar de fazer o TMAP.

Esses e outros fatores já foram relatados em estudos prévios. Em uma revisão conduzida por Hay-Smith et al. (2015) foram identificados como fatores modificadores da adesão ao TMAP a profundidade do conhecimento sobre o TMAP; as habilidades físicas necessárias para realizar o TMAP (i.e. consciência corporal dos MAP); os sentimentos 
relativos ao TMAP; a análise cognitiva, planejamento e atenção; priorização e; como ocorre a prestação do serviço. O estudo de Alewijnse et al. (2003b) identificou que a mulheres com maior frequência de perdas urinárias e com uma boa adesão a curto prazo apresentam uma boa adesão após um ano da interrupção do tratamento. Enquanto o estudo conduzido por Hyland, Hay-Smith \& Treharne (2013) identificou que a adaptabilidade do TMAP a diferentes locais e situações, uso de gatilhos para lembrar de realizar o TMAP, auto-eficácia, percepção de melhora dos sintomas, satisfação com a realização do exercício, percepção do TMAP e da família como prioridade poderiam influenciar a manutenção da adesão ao exercício. Ao analisarmos os fatores modificadores da adesão relatados nesse e outros estudos podemos perceber um padrão englobando três grandes grupos: fatores pessoais, ambientais e características do TMAP.

Como pode ser observado nos resultados, os relatos de melhora dos sintomas de disfunções do AP funcionaram como facilitador para aderir ao TMAP. Cabe destacar que um ECRC conduzido anteriormente com o mesmo grupo educativo demostrou que as orientações não proporcionaram melhora estatisticamente significativa nos sintomas de IU e DS (DE ANDRADE et al., 2018). Sendo assim, os relatos de melhora presente nos resultados dessa pesquisa não podem justificar o uso da atividade como tratamento, mas sim como atividade informativa com potencial para complementar o TMAP supervisionado, terapêutica considerada a primeira linha de tratamento para IU feminina (WOODLEY et al., 2017)

\subsection{IMPLICAÇÕES PRÁTICAS}

Ao refletir sobre tudo que foi discutido até o presente momento e considerando as especificidades do serviço seria interessante oferecer outros formatos de grupos educativos considerando a necessidade de tratamento do perfil identificado de mulheres participantes do grupo educativo. Um maior enfoque no tratamento conservador não-farmacológico, especificamente o TMAP e outras modificações dos hábitos de vida, seria uma possibilidade no contexto do serviço em questão, entretanto isso não impossibilita ou diminui a 
importância de oferecer-se grupos educativos de caráter informativo como o presente formato.

Para uma atividade objetivando o tratamento não-supervisionado o enfoque das discussões deveria ser o porquê se realizar o TMAP domiciliar, intensificar as práticas de TMAP no grupo, dando a oportunidade de mulheres passarem por uma avaliação física, e incorporar os fatores modificadores de adesão nas palestras e práticas de TMAP e manejo da auto eficácia individual. Desta forma poderemos buscar interromper o ato de terceirizar o cuidado da saúde. Essas estratégias deveriam ser incorporadas a atividades de educação em saúde e ao atendimento clinico em uma tentativa de melhorar tanto a adesão ao tratamento quanto a eficácia do mesmo. Estudos futuros são necessários para avaliar a eficácia, custobenefício e custo-efetividade dessa atividade de educação em saúde voltada ao tratamento dos sintomas de disfunções do AP para melhora ou cura dos sintomas de mulheres da comunidade.

\subsection{LIMITAÇÕES DO ESTUDO}

O presente estudo não utilizou de referencial teórico-metodológico ou as teorias de comportamento discutidas na elaboração dos tópicos que seriam abordados nas entrevistas. A construção de tópicos com embasamento nas teorias poderia obter uma percepção diferente das mulheres sobre a atividade educativa. Entretanto sua não utilização não invalida os achados do presente estudo uma vez que foram adotados critérios de qualidade internacionalmente reconhecidos. O reduzido número de participantes e a perda de followup, que poderiam ser considerados limitações em estudos quantitativos, não são limitações nesse estudo uma vez que houve saturação teórica dos dados referentes ao objetivo dessa pesquisa em cada fase de coleta. 


\section{CONCLUSÃO}

O grupo educativo informativo voltado ao AP feminino apresenta estrutura bem definida e adequada sob a perspectiva das mulheres. As mulheres pareceram ter uma boa aceitação da atividade para gerar modificação em hábitos de vida a curto e médio prazo entretanto ela reduz a longo prazo. Foram identificados várias barreiras e facilitadores para aderir as orientações do grupo educativo. Os facilitadores mais frequentes foram as informações discutidas no grupo educativo; o desejo das mulheres em melhorar, a o uso de lembretes como a cartilha entregue ao final do grupo educativo e associar o TMAP à AVDs. Já as principais barreiras foram não lembrar de realizar o TMAP, não entender como realizar o exercício, não reconhecer que tem disfunções do AP, a função da mulher como cuidadora e carga horária de trabalho culminando em uma falta de tempo 


\section{REFERÊNCIAS}

ABRAMS, P.; ANDERSSON, K.E.; BIRDER,L.; et al. Fourth international consultation on incontinence recommendations of the international scientific committee: evaluation and treatment of urinary incontinence, pelvicorgan prolapse, and fecal incontinence. Neurourology and Urodynamics, v. 29, p. 213-40, 2010.

ALEWIJNSE, D.; METSEMAKERS, J.F.M.; MESTERS, I.E.P.E.; et al. Efectiveness of Pelvic Floor Muscle Exercise Therapy Supplemented With a Health Education Program to Promote Long-Term Adherence Among Women With Urinary Incontinence. Neurourology and Urodynamics, v. 22, n. 4, p.284-95, 2003a.

; MESTERS, I.E.P.E.; METSEMAKERS,J.F.M.; et al. Predictors of longterm adherence to pelvic floor muscle exercise therapy among women with urinary incontinence. Health education research, v. 18, n. 5, p. 511-24, 2003 b.

ALVES, V. S. A health education model for the Family Health Program: towards comprehensive health care and model reorientation, Interface-Comunicação, Saúde, Educação,v.9, n.16, p.39-52, set.2004/fev.2005.

AYELEKE, R.O.; HAY-SMITH, E.J.C.; OMAR, M.I. Pelvic floor muscle training added to another active treatment versus the same active treatment alone for urinary incontinence in women. Cochrane Library, 2015.

BATISTA, R. A. L. Efeito de uma atividade educativa na função dos músculos do assoalho pélvico em mulheres: ensaio clínico randomizado e controlado. 2017. 81 f. Tese (Doutorado em Ciências) - Faculdade de Medicina de Ribeirão Preto, Universidade de São Paulo, Ribeirão Preto, 2017.

BERZUK, K.; SHAY, B. Effect of increasing awareness of pelvic floor muscle function on pelvic floor dysfunction: a randomized controlled trial. International urogynecology journal, v. 26, p. 837-844, 2015.

BO, K. Overview of physical therapy for pelvic floor dysfunction. IN:BO,K.; BERGHMANS,B.; MORKVED, S.; VANKAMPEN, M. Evidence-based physical therapy for the pelvic floor. $2^{\mathrm{a}} \mathrm{ed}, \mathrm{p} .1,2015$.

BO, K.; SHERBURN, M. Evaluation of female pelvic floor muscle function and strength. Physical Therapy, v. 85, n. 3, p. 269-82, 2005.

BRAUN, V.; CLARKE, V. Using thematic analysis in psychology. Qualitative research in psychology. v.3, p.77-101, 2006.

BUSS, P.M. Promoção e educação em saúde no âmbito da Escola de Governo em Saúde da Escola Nacional de Saúde Pública. Caderno de Saúde Pública, v.15, p. 177-85,1999. 
CARLINI-COTRIM, B. Potencialidades da técnica qualitativa grupo focal em investigações sobre abuso de substâncias. Revista de Saúde Pública, v.30, n.3, p. 285-93, 1996.

CARPENTER, C.; SUTO, M. Qualitative research for occupational and physical therapists: A practical guide Oxford: Black-Well Publishing; 2008.

CHIARELLI, P; COCKBURN, J. The development of a physiotherapy continence promotion program using a customer focus. Australian Journal of Physiotherapy, v. 45, n. 2, p. 111-119, 1999.

DE ANDRADE, R.L.; B $\emptyset$, K.; ANTONIO, F.I., et al. An education program about pelvic floor muscles improved women's knowledge but not pelvic floor muscle function, urinary incontinence or sexual function: a randomised trial. Journal of physiotherapy, v.64, p.9196. 2018,

DE FREITAS, L.M.; BØ, K.; FERNANDES, A.C.N.L., et al. Pelvic floor muscle knowledge and relationship with muscle strength in Brazilian women: a cross-sectional study. International urogynecology journal, 2018, 1-7 [Epub ahead of print].

DIOKNO, A.C.; NEWMAN, D.K.; LOW, L.K., et al. Effect of Group-Administered Behavioral Treatment on Urinary Incontinence in Older Women: A Randomized Clinical Trial. JAMA internal medicine, v.178, p. 1333-1341, 2018.

DOSHANI, A.; PITCHFORTH, E.; MAYNE, J.C.; et al. Culturally sensitive continence care: a qualitative study among South Asian Indian women in Leicester. Family Practice, v.24, p. 585-93, 2007.

DUMOULIN, C.; HAY-SMITH, J.; FRAWLEY,H. et al. 2014 consensus statement on improving pelvic floor muscle training adherence :International Continence Society 2011 State-of-the-ScienceSeminar. Neurourology and Urodynamics, v.34 p. 600-5, 2015.

ENTWISTLE, V.A.; RENFREW, M.J.; YEARLEY, S. et al. Lay perspectives: advantages for health research. BMJ: British medical journal v. 316, 1998.

GLISOI, S.F.N.; GIRELLI, P. Importância da fisioterapia na conscientização e aprendizagem da contração da musculatura do assoalho pélvico em mulheres com incontinência. Revista da Sociedade Brasileira de v. 9, p. 408-13, 2011.

HAY-SMITH, E.J.; HERDERSCHEE, R.; DUMOULIN, C.; et al. Comparisons of approaches to pelvic floor muscle training for urinary incontinencein women. Cochrane Database Syst Rev., n. 12, 2011.

HAY-SMITH, J.; DEAN, S.; BURGIO, K., et al. Pelvic-floor-muscle-training adherence "modifiers": a review of primary qualitative studies-2011 ICS State-of-the-Science Seminar research paper III of IV. Neurourology and urodynamics, v. 34, p. 622-631, 2015. 
HAY-SMITH, E.J.C.; MCCLURG, D.; FRAWLEY, H.; et al. Exercise adherence: integrating theory, evidence and behaviour change techniques. Physiotherapy, v. 102, n. 01, p. 7-9, 2016.

HÄGGLUND, D.; AHLSTRÖM, G. The meaning of women's experience of living with long-term urinary incontinence is powerlessness. Journal of Clinical Nursing, v.16, n.10, p. 1946-54, 2007.

HERBRUCKL.F. Stress urinary incontinence: prevention, management, and provider education. Urologic nursing, v.28, n.3, p, 200-6, 2008.

HINES, S.H.; SENG, J.S.; MESSER, K.L.; et al. Adherence to a behavioral program to prevent incontinence. Western journal of nursing research, v.29, n.1, p.36-56, 2007.

HYAKUTAKE et al. Pelvic Floor Health Education: Can a Workshop Enhance Patient Counseling During Pregnancy?. Female Pelvic Medicine \& Reconstructive Surgery, Hagerstown, v. 22, n. 5, p. 336-339, 2016.

HYLAND, G.; HAY-SMITH, J.; TREHARNE, G. Women's experiences of doing long-term pelvic floor muscle exercises for the treatment of pelvic organ prolapse symptoms. International urogynecology journal, v. 25, n. 2, p. 265-271, 2014.

IERVOLINO, S.A.; PELICIONI, M.C.F. A utilização do grupo focal como metodologia qualitativa na promoção da saúde. Revista da Escola de Enfermagem da USP, v. 35, n.2, p.115-21, jun, 2001.

INSTITUTO BRASILEIRO DE GEOGRAFIA EESTATÍSTICA-IBGE. Atlas do censo demográfico 2010, Rio de Janeiro: IBGE, 2013.

KAO, H.T.; HAYTER, M.; HINCHLIFF, S.; et al. Experience of pelvic floor muscle exercises among women in Taiwan: a qualitative study of improvement in urinary incontinence and sexuality. Journal of clinical nursing, v. 24, n. 13-14, p. 1985-94, 2015.

KANDADAI, P.; O'DELL, K.; SAINI, J. Correct performance of pelvic muscle exercises in women reporting prior knowledge. Female Pelvic Medicine \& Reconstructive Surgery, 2014.

LINCOLN, Y.S.; GUBA, E.G. Lincoln and Guba's Evaluative Criteria. Robert Wood Johnson Foundation, 1985. Disponível em: < http://www.qualres.org/HomeLinc3684.html>

MATTOS R.A. A integralidade na prática (ou sobre a prática da integralidade). Caderno de Saúde Pública, v. 20, n. 5, p. 1411-6, 2004.

MARGALITH, I.; GILLON, G.; GORDON, D. Urinary incontinence in women under 65: quality of life, stress related to incontinence and patterns of seeking health care. Quality of Life research, v. 13, n. 8, p. 1381-1390, 2004. 
NEELS, H.; WYNDAELE, J.J.; TJALMA, W.A., et al. Knowledge of the pelvic floor in nulliparous women. Journal of Physical Therapy Science, v. 28, n.5, p. 1524-33, 2016 a.

NEELS, H.; TJALMA, W.A.; WYNDAELE, J.J., et al. Knowledge of the pelvic floor in menopausal women and in peripartum women. Journal of Physical Therapy Science, v. 28 , n. 11 , p. $3020-9,2016$ b.

O'BRIEN, B.C.; HARRIS, I.B.; BECKMAN, T.J.; et al. Standards for reporting qualitative research: a synthesis of recommendations. Academic Medicine. v.89, n.9, p.1245-51, 2014.

OUCHI, M.; KITTA, T.; KANNO, Y., et al. Medium-term follow-up after supervised pelvic floor muscle training for patients with anterior vaginal wall prolapse. European Journal of Obstetrics \& Gynecology and Reproductive Biology, v. 225, p. 95-100, 2018.

RIMMER, C.J.; GILL, K.A.; GREENFIELD, S.; et al. The design and initial patient evaluation of an integrated care pathway for faecal incontinence: a qualitative study. BMC: Health Services Research. 2015.

ROOS, A.M.; THAKAR, R.; SULTAN, A.H.; et al. The impact of pelvic floor surgery on female sexual function: a mixed quantitative and qualitative study. BJOG: An International Journal of Obstetrics \& Gynaecology. v.121, n.1, p.92-100, 2014.

ROSENSTOCK, I.M.; STRECHER, V.J.; BECKER, M.H. Social learning theory and the health belief model. Health education quarterly, v. 15, p. 175-83, 1988.

SMITH, A.L.; NISSIM, H.A.; LE, T.X.; et al. Misconceptions And Miscommunication Among Aging Women With Overactive Bladder Symptoms. Urology, v.77, n. 1 p. 55-9, 2011.

STADNICKA, G.; IWANOWICZ-PALUS, G.J.; BIEŃ, A.M. A Prophylactic program for strain urinary incontinence WiadLek. v. 55, p. 890-4, 2002.

TAMANINI, J.T.N.; PALLONE, L.V.; SARTORI, M.G.F.; et al. A population - based survey on the prevalence, incidence, and risk factors of urinary incontinence in older adults - results from the "SABE STUDY". Neurourology and Urodynamics, 2017.

TONG, A.; SAINSBURY, P.; CRAIG, J. Consolidated criteria for reporting qualitative research (COREQ): a 32-item checklist for interviews and focus groups. International journal for quality in health care, v.19, n.6, p.349-57, 2007.

TOL, A.; ALHANI, F; SHOJAEAZADEH, D., et al. An empowering approach to promote the quality of life and self-management among type 2 diabetic patients. Journal of education and health promotion, 4, 2015.

WESTPHAL, M.F; BÓGUS, C.M.; FARIA, M.M. Grupos focais: experiências precursoras em programas educativos em saúde no Brasil. Bol Oficina Sanit Panam, v.120, n.6, 1996. 
WOODLEY, S.J.; BOYLE, R.; CODY, J.D. et al. Pelvic floor muscle training for prevention and treatment of urinary and faecal incontinence in antenatal and postnatal women. The Cochrane Library. 2017.

WU, J.M.; VAUGHAN,C. P.; GOODE, P.S. et al. Prevalence and Trends of Symptomatic Pelvic Floor Disorders in U.S. Women. Obstetrics and gynecology, v.123, n.1, p. 141-8, 2014.

YIOU, R.; COSTA, P.; HAAB,F.; et al. Anatomie fonctionnelledu plancher pelvien. Progrès enUrologie. v.19, p. 916-25, 2009.

ZACCARDI, J.E.; WILSON, L.; MOKRZYCKI, M.L. The effect of pelvic floor reeducation on comfort in women having surgery for stress urinary incontinence. Urologic Nursing, v.30, n.2, p. 137-46, 2010.

ZHANG, N.; HE, Y.; WANG, J., et al. Effects of a new community-based reproductive health intervention on knowledge of and attitudes and behaviors toward stress urinary incontinence among young women in Shanghai: a cluster-randomized controlled trial. International urogynecology journal, v. 27, p. 545-553, 2016. 


\title{
9. APÊNDICES
}

\section{APÊNDICE A- TERMO DE CONSENTIMENTO LIVRE E ESCLARECIDO}

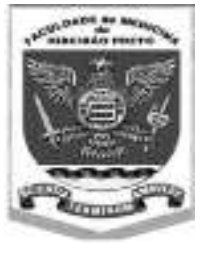

\author{
HOSPITAL DASCLÍNICAS DA FACULDADE DE \\ MEDICINA DE RIBEIRÃO PRETO DA \\ UNIVERSIDADE DE SÃO PAULO
}

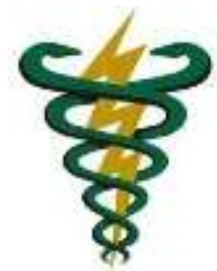

Prédio da Fisioterapia e Terapia Ocupacional, $2^{\circ}$ andar-sala B13- Ribeirão Preto/SP

\section{Termo De Consentimento Livre E Esclarecido}

Estamos realizando uma pesquisa intitulada Percepção de um grupo de mulheres sobre uma atividade educativa voltada à reabilitação do assoalho pélvico feminino: estudo qualitativo. Participarão do estudo mulheres que fizeram parte do grupo de educação do assoalho pélvico no CSE ou LAFAP para avaliarmos as atividades desse grupo educativo sob o ponto de vista de quem realmente importa: você!

Por ter participado de um dos grupos, gostaríamos de convidá-la para fazer parte do nosso estudo, mas para que você possa decidir se gostaria ou não de participar, vamos te passar detalhes da pesquisa. Se houver alguma dúvida fique à vontade para perguntar em qualquer momento.

O principal objetivo desta pesquisa é avaliar se o conteúdo da atividade educativa que você participou foi adequado e útil, se o formato, os termos utilizados e as orientações sobre as contrações dos músculos do assoalho pélvico foram bem compreendidas. Também temos como objetivos avaliar se a atividade educativa é adequada a ponto de gerar modificação nos seus hábitos de vida a curto, médio e longo prazo, e refletir sobre a possibilidade de reformulações desta atividade e elaboração de novas propostas diante da perspectiva das participantes. Os resultados dessa pesquisa serão divulgados e publicados, porém fica garantido o sigilo sobre sua identidade sendo seu nome substituído por um código.

Se você concordar em participar da pesquisa irá responder um questionário com perguntas sobre seus dados pessoais, ocupacionais, nível socioeconômico e de escolaridade. Logo após participará de um grupo focal, um grupo de discussão que vai funcionar como um júri composto pelas participantes do seu grupo educativo mais duas fisioterapeutas. Uma fisioterapeuta será a observadora e ficará responsável por coordenar a gravação do áudio da discussão e a outra será a guia, responsável por dizer os tópicos que serão julgados por vocês. A gravação será utilizada pelo observador para transcrever tudo que foi discutido 
palavra por palavra e você não será identificada nela. Essa dinâmica será realizada em três momentos: uma semana, três e seis meses depois do final do grupo educativo.

A sua participação neste estudo é voluntária, sendo seu direito deixar de participar quando desejar sem que isso cause penalidade ou prejuízo de qualquer modo.

Tendo recebido as informações acima e ciente dos meus direitos abaixo relacionados, $\mathrm{Eu}$,

$\mathrm{RG}$ enquanto participante deste estudo fica garantido:

, abaixo assinada, concordo em participar do estudo. A mim,

1. Receber resposta a qualquer pergunta ou esclarecimento a qualquer dúvida acerca dos procedimentos, riscos, benefícios e outras questões relacionadas com a pesquisa e com o tratamento a qual serei submetida; 2 . Ter liberdade de retirar meu consentimento a qualquer momento e deixar de participar do estudo, sem que isso traga prejuízo à continuação do meu cuidado e tratamento; 3 . Ter segurança de que não serei identificada e que será mantido o caráter confidencial da informação relacionada com a minha privacidade; 4 . O compromisso de me proporcionar informação atualizada durante o estudo, ainda que esta possa afetar minha vontade de continuar participando; 5. Que se existirem gastos adicionais, estes serão absorvidos pelo orçamento da pesquisa. Não haverá recompensa financeira para as pacientes que participarem do estudo;

Tenho ciência do exposto acima e desejo participar do projeto de pesquisa.

Ribeirão Preto, de de

Assinatura da Paciente

Assinatura da Pesquisadora Responsável

Para maiores informações e esclarecimentos entre em contato com as pesquisadoras Ana Carolina Nociti Lopes Fernandes (17991255185), Leticia Maciel de Freitas (19992532207), Natalia Uechi (16988758373), Professora Dra Cristine Homsi Jorge Ferreira (33150741) ou com o Centro de Saúde Escola (CSE) - 3315000 


\title{
APÊNDICE B- QUESTIONÁRIO CLÍNICO
}

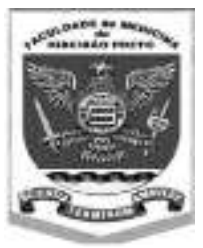

\author{
HOSPITAL DASCLÍNICAS DAFACULDADE DE \\ MEDICINADERIBEIRÃOPRETODA \\ UNIVERSIDADEDESÃOPAULO
}

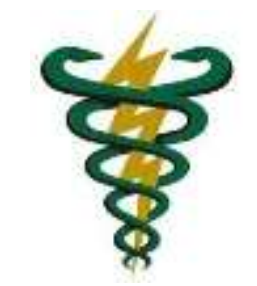

Prédio da Fisioterapia e Terapia Ocupacional, $2^{\circ}$ andar-sala B13- Ribeirão Preto/SP

\section{Questionário Clínico}

\section{CÓDIGO:}

Data:

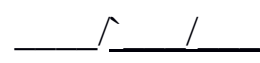

Nome:

DN:____ Idade:__ anos RG:_ CPF:

Endereço:

Profissão:

Escolaridade:

Religião:

Estado Civil: ( ) Casada ( ) Solteira ( ) Amigada ( ) Separada ( ) Outros:

Cor: ( ) Branca ( ) Parda ( ) Negra ( ) Outros:

G_ P_ (N _ C C _ $)$ A _ DUP: __________ Uso de CTO: ( ) Sim ( ) Não

Gestante: ( ) Sim ( ) Não Se sim: IG: semanas DUM:

Climatérica: ( ) Sim ( ) Não Se sim: DUM: I__ Uso de TH: ( ) Sim ( )

Não

Tem ou já teve perda de urina? ( ) Sim ( ) Não Duração do Sintoma:

Se sim: Quando acontece/cia: Faz ou fez tratamento? ( ) Sim ( ) Não

Se sim, qual:

Observações:

Tem ou já teve perda de fezes? ( ) Sim ( ) Não Duração do Sintoma:

Se sim: Quando acontece/cia: Faz ou fez tratamento? ( ) Sim ( ) Não

Se sim, qual:

Observações:

Tem ou já teve constipação? ( ) Sim ( ) Não Duração do Sintoma:

Se sim: Quando acontece/cia: Faz ou fez tratamento? ( ) Sim ( ) Não Se sim, qual: 
Observações:

Tem ou já teve prolapso dos órgãos pélvicos? ( ) Sim ( ) Não Duração do Sintoma: Se sim: Faz ou fez tratamento? ( ) Sim ( ) Não Se sim, qual:

Observações:

Tem ou já teve disfunção sexual? ( ) Sim ( ) Não Duração do Sintoma:

Se sim: Qual:

Faz ou fez tratamento? ( ) Sim ( ) Não

Se sim, qual:

Observações: 
APÊNDICE C - FICHA DE CONTROLE

HOSPITAL DASCLÍNICAS DAFACULDADE DE

MEDICINADERIBEIRÃOPRETODA

UNIVERSIDADEDESÃOPAULO

Prédio da Fisioterapia e Terapia Ocupacional, $2^{\circ}$ andar-sala B13- Ribeirão Preto/SP

Ficha de Controle

Dinâmica inicial:

\begin{tabular}{|c|c|c|c|}
\hline \multicolumn{3}{|c|}{ Anatomia Feminina (Dia 1) } \\
\hline Conteúdo & Sim & Não & Termos, associações, material didático \\
\hline Genitália externa & & & \\
\hline Órgãos internos & & & \\
\hline Estrutura MAP & & & \\
\hline Função MAP & & & \\
\hline Fisiologia da & & & \\
Micção + stop test & & & \\
\hline Prática Corporal & & & \\
\hline \multicolumn{2}{|c|}{ Disfunções MAP (Dia 2) } \\
\hline Conteúdo & Sim & Não & Termos, associações, material didático \\
\hline $\begin{array}{c}\text { Incontinência } \\
\text { Urinária (tipos e } \\
\text { fatores de risco) }\end{array}$ & & & \\
\hline $\begin{array}{c}\text { Disfunções } \\
\text { intestinais } \\
\text { (incontinência e } \\
\text { constipação) }\end{array}$ & & & \\
\hline $\begin{array}{c}\text { Distopia dos órgãos } \\
\text { pélvicos }\end{array}$ & & & \\
\hline $\begin{array}{c}\text { Disfunções sexuais } \\
\text { Prática Corporal }\end{array}$ & & & \\
\hline \begin{tabular}{l} 
Observações \\
\hline
\end{tabular} & & & \\
\hline
\end{tabular}




\begin{tabular}{|c|c|c|c|}
\hline \multicolumn{2}{|c|}{ Tratamento (Dia 3) } \\
\hline $\begin{array}{c}\text { Conteúdo } \\
\text { Tratamento médico } \\
\text { conservador e } \\
\text { cirúrgico) }\end{array}$ & Sim & Não & Termos, associações, material didático \\
\hline $\begin{array}{c}\text { Tratamento } \\
\text { fisioterapêutico }\end{array}$ & & & \\
\hline $\begin{array}{c}\text { Avaliação } \\
\text { Fisioterapêutica }\end{array}$ & & & \\
\hline $\begin{array}{c}\text { Orientação } \\
\text { protocolo de } \\
\text { tratamento }\end{array}$ & & & \\
\hline $\begin{array}{c}\text { Estratégia para } \\
\text { inibir urgência } \\
\text { miccional }\end{array}$ & & & \\
\hline $\begin{array}{c}\text { Prática de } \\
\text { exercícios MAP }\end{array}$ & & & \\
\hline Observações & & & \\
\hline \multicolumn{2}{|c|}{} & & Resumo (Dia 4) \\
\hline $\begin{array}{c}\text { Entrega e } \\
\text { explicação da } \\
\text { cartilha } \\
\text { participano das }\end{array}$ & & Não & Termos, associações, material didático \\
\hline $\begin{array}{c}\text { Observações } \\
\text { Conteúdo }\end{array}$ & Sim & & \\
\hline Dia 1 & & & \\
\hline Dia 2 & & & \\
\hline Dia 3 & & & \\
\hline & & & \\
\hline
\end{tabular}




\title{
ANEXO A - CHECK LIST DO STANDARDS FOR REPORTING QUALITATIVE RESEARCH
}

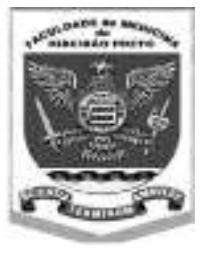

\author{
HOSPITAL DASCLÍNICAS DA FACULDADE \\ DE MEDICINA DE RIBEIRÃO PRETO DA \\ UNIVERSIDADE DE SÃO PAULO
}

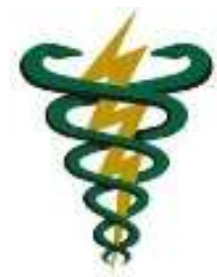

Prédio da Fisioterapia e Terapia Ocupacional, $2^{\circ}$ andar-sala B13- Ribeirão Preto/SP

Check list do Standards for Reporting Qualitative Research (SRQR)

\begin{tabular}{|c|c|c|}
\hline No & Item & Guide questions/description \\
\hline & Title and abstract & \\
\hline S1 & Title & $\begin{array}{l}\text { Concise description of the nature and topic of the study Identifying the study as } \\
\text { qualitative or indicating the approach (e.g., ethnography, grounded theory) or data } \\
\text { collection methods (e.g., interview, focus group) is recommended }\end{array}$ \\
\hline \multirow[t]{2}{*}{$\mathrm{S} 2$} & Abstract & $\begin{array}{l}\text { Summary of key elements of the study using the abstract format of the intended } \\
\text { publication; typically includes background, purpose, methods, results, and } \\
\text { conclusions }\end{array}$ \\
\hline & Introduction & \\
\hline S3 & Problem formulation & $\begin{array}{l}\text { Description and significance of the problem/phenomenon studied; review of } \\
\text { relevant theory and empirical work; problem statement }\end{array}$ \\
\hline \multirow[t]{2}{*}{$\mathrm{S} 4$} & $\begin{array}{l}\text { Purpose or research } \\
\text { question }\end{array}$ & Purpose of the study and specific objectives or questions \\
\hline & Methods & \\
\hline S5 & $\begin{array}{l}\text { Qualitative approach } \\
\text { and research } \\
\text { paradigm }\end{array}$ & $\begin{array}{l}\text { Qualitative approach (e.g., ethnography, grounded theory, case study, } \\
\text { phenomenology, narrative research) and guiding theory if appropriate; identifying } \\
\text { the research paradigm (e.g., postpositivist, constructivist/interpretivist) is also } \\
\text { recommended; rationale }\end{array}$ \\
\hline S6 & $\begin{array}{l}\text { Researcher } \\
\text { characteristics and } \\
\text { reflexivity }\end{array}$ & $\begin{array}{l}\text { Researchers' characteristics that may influence the research, including personal } \\
\text { attributes, qualifications/experience, relationship with participants, assumptions, } \\
\text { and/or presuppositions; potential or actual interaction between researchers' } \\
\text { characteristics and the research questions, approach, methods, results, and/or } \\
\text { transferability }\end{array}$ \\
\hline S7 & Context & Setting/site and salient contextual factors; rationale \\
\hline S8 & Sampling strategy & $\begin{array}{l}\text { How and why research participants, documents, or events were selected; criteria } \\
\text { for deciding when no further sampling was necessary (e.g., sampling saturation); } \\
\text { rationale }\end{array}$ \\
\hline S9 & $\begin{array}{c}\text { Ethical issues } \\
\text { pertaining to human }\end{array}$ & $\begin{array}{l}\text { Documentation of approval by an appropriate ethics review board and participant } \\
\text { consent, or explanation for lack thereof; other confidentiality and data security }\end{array}$ \\
\hline
\end{tabular}




\begin{tabular}{|c|c|c|}
\hline & subjects & issues \\
\hline S10 & $\begin{array}{l}\text { Data collection } \\
\text { methods }\end{array}$ & $\begin{array}{l}\text { Types of data collected; details of data collection procedures including (as } \\
\text { appropriate) start and stop dates of data collection and analysis, iterative process, } \\
\text { triangulation of sources/methods, and modification of procedures in response to } \\
\text { evolving study findings; rationale }\end{array}$ \\
\hline S11 & $\begin{array}{l}\text { Data collection } \\
\text { instruments and } \\
\text { technologies }\end{array}$ & $\begin{array}{l}\text { Description of instruments (e.g., interview guides, questionnaires) and devices } \\
\text { (e.g., audio recorders) used for data collection; if/how the instrument(s) changed } \\
\text { over the course of the study }\end{array}$ \\
\hline $\mathrm{S} 12$ & Units of study & $\begin{array}{l}\text { Number and relevant characteristics of participants, documents, or events } \\
\text { included in the study; level of participation (could be reported in results) }\end{array}$ \\
\hline S13 & Data processing & $\begin{array}{l}\text { Methods for processing data prior to and during analysis, including transcription, } \\
\text { data entry, data management and security, verification of data integrity, data } \\
\text { coding, and anonymization/deidentification of excerpts }\end{array}$ \\
\hline S14 & Data analysis & $\begin{array}{c}\text { Process by which inferences, themes, etc., were identified and developed, } \\
\text { including the researchers involved in data analysis; usually references a specific } \\
\text { paradigm or approach; rationale }\end{array}$ \\
\hline \multirow[t]{2}{*}{$\mathrm{S} 15$} & $\begin{array}{l}\text { Techniques to } \\
\text { enhance } \\
\text { trustworthiness }\end{array}$ & $\begin{array}{l}\text { Techniques to enhance trustworthiness and credibility of data analysis (e.g., } \\
\text { member checking, audit trail, triangulation); rationale }\end{array}$ \\
\hline & Results/Findings & \\
\hline S16 & $\begin{array}{l}\text { Synthesis and } \\
\text { interpretation }\end{array}$ & $\begin{array}{l}\text { Main findings (e.g., interpretations, inferences, and themes); might include } \\
\text { development of a theory or model, or integration with prior research or theory }\end{array}$ \\
\hline \multirow[t]{2}{*}{ S17 } & $\begin{array}{l}\text { Links to empirical } \\
\text { data }\end{array}$ & $\begin{array}{l}\text { Evidence (e.g., quotes, field notes, text excerpts, photographs) to substantiate } \\
\text { analytic findings }\end{array}$ \\
\hline & Discusssion & \\
\hline S18 & $\begin{array}{l}\text { Integration with prior } \\
\text { work, implications, } \\
\text { transferability, and } \\
\text { contribution(s) to the } \\
\text { field }\end{array}$ & $\begin{array}{l}\text { Short summary of main findings; explanation of how findings and conclusions } \\
\text { connect to, support, elaborate on, or challenge conclusions of earlier scholarship; } \\
\text { discussion of scope of application/ generalizability; identification of unique } \\
\text { contribution(s) to scholarship in a discipline or field }\end{array}$ \\
\hline \multirow[t]{2}{*}{ S19 } & Limitations & Trustworthiness and limitations of findings \\
\hline & Other & \\
\hline $\mathrm{S} 20$ & Conflicts of interest & $\begin{array}{l}\text { Potential sources of influence or perceived influence on study conduct and } \\
\text { conclusions; how these were managed }\end{array}$ \\
\hline $\mathrm{S} 21$ & Funding & $\begin{array}{c}\text { Sources of funding and other support; role of funders in data collection, } \\
\text { interpretation, and reporting }\end{array}$ \\
\hline
\end{tabular}




\title{
ANEXO B - CHECK LIST DO CONSOLIDATED CRITERIA FOR REPORTING QUALITATIVE RESEARCH
}

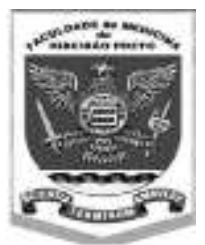

\author{
HOSPITAL DASCLÍNICAS DA FACULDADE \\ DE MEDICINA DE RIBEIRÃO PRETO DA \\ UNIVERSIDADE DE SÃO PAULO
}

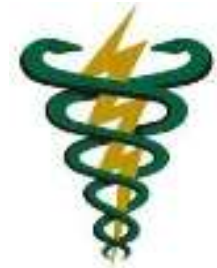

Prédio da Fisioterapia e Terapia Ocupacional, $2^{\circ}$ andar-sala B13- Ribeirão Preto/SP

\section{Check list do Consolidated Criteria For Reporting Qualitative Research}

\begin{tabular}{|c|c|c|}
\hline No & Item & Guide questions/description \\
\hline \multicolumn{3}{|c|}{ Domain 1: Research team and reflexivity } \\
\hline \multicolumn{3}{|l|}{$\begin{array}{c}\text { Personal } \\
\text { Characteristics } \\
\end{array}$} \\
\hline 1. & Interviewer/facilitator & Which author/s conducted the interview or focus group? \\
\hline 2. & Credentials & What were the researcher's credentials? E.g. PhD, MD \\
\hline 3. & Occupation & What was their occupation at the time of the study? \\
\hline 4. & Gender & Was the researcher male or female? \\
\hline 5. & Experience and training & What experience or training did the researcher have? \\
\hline \multicolumn{3}{|l|}{$\begin{array}{l}\text { Relationship with } \\
\text { participants }\end{array}$} \\
\hline 6. & Relationship established & Was a relationship established prior to study commencement? \\
\hline 7. & $\begin{array}{l}\text { Participant knowledge of the } \\
\text { interviewer }\end{array}$ & $\begin{array}{c}\text { What did the participants know about the researcher? e.g. } \\
\text { personal goals, reasons for doing the research }\end{array}$ \\
\hline 8. & Interviewer characteristics & $\begin{array}{c}\text { What characteristics were reported about the } \\
\text { interviewer/facilitator? e.g. Bias, assumptions, reasons and } \\
\text { interests in the research topic }\end{array}$ \\
\hline \multicolumn{3}{|c|}{ Domain 2: study design } \\
\hline $\begin{array}{l}\text { Theoretical } \\
\text { framework }\end{array}$ & & \\
\hline 9. & $\begin{array}{l}\text { Methodological orientation and } \\
\text { Theory }\end{array}$ & $\begin{array}{l}\text { What methodological orientation was stated to underpin the } \\
\text { study? e.g. grounded theory, discourse analysis, ethnography, } \\
\text { phenomenology, content analysis }\end{array}$ \\
\hline
\end{tabular}




\begin{tabular}{|c|c|c|}
\hline $\begin{array}{c}\text { Participant } \\
\text { selection }\end{array}$ & & \\
\hline 10. & Sampling & $\begin{array}{l}\text { How were participants selected? e.g. purposive, convenience, } \\
\text { consecutive, snowball }\end{array}$ \\
\hline 11. & Method of approach & $\begin{array}{c}\text { How were participants approached? e.g. face-to-face, telephone, } \\
\text { mail, email }\end{array}$ \\
\hline 12. & Sample size & How many participants were in the study? \\
\hline 13. & Non-participation & $\begin{array}{l}\text { How many people refused to participate or dropped out? } \\
\text { Reasons? }\end{array}$ \\
\hline \multicolumn{3}{|l|}{ Setting } \\
\hline 14. & Setting of data collection & Where was the data collected? e.g. home, clinic, workplace \\
\hline 15. & Presence of non-participants & $\begin{array}{l}\text { Was anyone else present besides the participants and } \\
\text { researchers? }\end{array}$ \\
\hline 16. & Description of sample & $\begin{array}{l}\text { What are the important characteristics of the sample? e.g. } \\
\text { demographic data, date }\end{array}$ \\
\hline \multicolumn{3}{|l|}{ Data collection } \\
\hline 17. & Interview guide & $\begin{array}{l}\text { Were questions, prompts, guides provided by the authors? Was it } \\
\text { pilot tested? }\end{array}$ \\
\hline 18. & Repeat interviews & Were repeat interviews carried out? If yes, how many? \\
\hline 19. & Audio/visual recording & $\begin{array}{l}\text { Did the research use audio or visual recording to collect the } \\
\text { data? }\end{array}$ \\
\hline 20. & Field notes & $\begin{array}{l}\text { Were field notes made during and/or after the interview or focus } \\
\text { group? }\end{array}$ \\
\hline 21. & Duration & What was the duration of the interviews or focus group? \\
\hline 22. & Data saturation & Was data saturation discussed? \\
\hline 23. & Transcripts returned & $\begin{array}{l}\text { Were transcripts returned to participants for comment and/or } \\
\text { correction? }\end{array}$ \\
\hline \multicolumn{3}{|c|}{ Domain 3: analysis and findingsz } \\
\hline \multicolumn{3}{|l|}{ Data analysis } \\
\hline 24. & Number of data coders & How many data coders coded the data? \\
\hline 25. & Description of the coding tree & Did authors provide a description of the coding tree? \\
\hline 26. & Derivation of themes & Were themes identified in advance or derived from the data? \\
\hline 27. & Software & What software, if applicable, was used to manage the data? \\
\hline
\end{tabular}




\begin{tabular}{|c|c|c|}
\hline 28. & Participant checking & Did participants provide feedback on the findings? \\
\hline \multicolumn{3}{|c|}{ Reporting } \\
\hline 29. & Quotations presented & $\begin{array}{l}\text { Were participant quotations presented to illustrate the themes / } \\
\text { findings? Was each quotation identified? e.g. participant number }\end{array}$ \\
\hline 30. & Data and findings consistent & $\begin{array}{l}\text { Was there consistency between the data presented and the } \\
\text { findings? }\end{array}$ \\
\hline 31. & Clarity of major themes & Were major themes clearly presented in the findings? \\
\hline 32. & Clarity of minor themes & $\begin{array}{c}\text { Is there a description of diverse cases or discussion of minor } \\
\text { themes? }\end{array}$ \\
\hline
\end{tabular}

